\title{
Kristel Proost \\ Ditransitive transfer constructions and their prepositional variants in German and Romanian: An empirical survey ${ }^{1}$
}

\begin{abstract}
This contribution offers a fine-grained analysis of German and Romanian ditransitive and prepositional transfer constructions. The transfer construction (TC) is shown to be realised in German by 26 argument structure patterns (ASPs), which are conceived of as form-meaning pairings which differ only minimally. The mainstream constructionist view of the different types of TCs being related by polysemy links is rejected, the ASPs being argued instead to be related by family relationships. All but six of the ASPs identified for German are shown to possess a Romanian counterpart. For some ditransitive structures, German is shown to possess two prepositional variants, one with $a n$ ('at') and one with $z u$ ('to') or auf ('on'), while Romanian has only one. Due to the lack of a Romanian counterpart for the German $z u$ and $a u f$ variants, Romanian lacks some of the dative alternations found in German. However, Romanian as well as German permits the double object pattern to interact with take-verbs, verbs of removal and $a d d$-verbs, which do not allow the ditransitive construction in English. Since these verb classes also permit at least one prepositional pattern in both languages, Romanian and German show a larger number of dative alternation types than English.

In diesem Beitrag werden deutsche und rumänische ditransitive und präpositionale Transfer-Konstruktionen feinkörnig analysiert. Es wird gezeigt, dass die Transfer-Konstruktion (TC) im Deutschen durch 26 Argumentstrukturmuster (ASPs: argument structure patterns), d.h. minimal unterschiedliche FormBedeutungspaare, realisiert ist. Die gängige konstruktionsgrammatische Auffassung, nach der die unterschiedlichen Typen von Transfer-Konstruktionen durch Polysemiebeziehungen miteinander verbunden sind, wird zugunsten eines Modells verworfen, das von Verwandtschaftsbeziehungen zwischen unterschiedlichen Transfer-Konstruktionen ausgeht. Alle bis auf sechs dieser ASP haben eine Entsprechung im Rumänischen. Während es im Deutschen in manchen Fällen zwei präpositionale Entsprechungen für eine einzige ditransitive Struktur gibt, nämlich eine mit an ('at') und eine mit $z u$ ('to') oder auf ('on'), weist das Rumänische jeweils nur eine präpositionale Variante für eine ditransitive Struktur auf. Demzufolge fehlen im Rumänischen manche Typen der Dativalternationen, die im Deutschen möglich

1 I thank Ruxandra Cosma and Alina Tigău (University of Bucharest) for providing me with the Romanian examples listed in this text. I am also grateful to Alexandra Cornilescu and Ruxandra Cosma (both University of Bucharest) as well as Stefan Engelberg and Gisela Zifonun (both IDS) for their comments on an earlier version of this article.
\end{abstract}


sind. Das Doppel-Objekt-Muster tritt aber sowohl im Deutschen als auch im Rumänischen mit nehmenVerben, entfernen-Verben und hinzufügen-Verben auf, die im Englischen nicht mit der Ditransitiv-Konstruktion vorkommen. Da diese Verben in beiden Sprachen auch mit mindestens einem präpositionalen Muster vorkommen können, weisen sowohl das Rumänische als auch das Deutsche insgesamt eine gröBere Anzahl an unterschiedlichen Typen von Dativalternationen auf.

\section{Introduction: Transfer constructions vs. benefactive constructions}

A transfer construction (TC) is a construction which pairs a transfer meaning either with a ditransitive pattern, i.e. a pattern consisting of a verb, a subject-NP and two object-NPs, or with a pattern consisting of a verb, a subject-NP, an object-NP and a PP. Transfer here is understood to cover cases where an entity is caused to go from one location to another, where a location may be either a physical entity such as the place where the transferred entity originates from or is caused to go to or an animate entity such as an Agent or a Recipient. Ditransitive transfer constructions have been dealt with extensively from a variety of different perspectives, both theoretical and empirical, with respect to English (cf. Green 1974; Oehrle 1976; Allerton 1978; Erteschik-Shir 1979; Larson 1988; Levin 1993; Goldberg 1995; Rappaport Hovav/Levin 2008 among others). Ditransitive constructions have been studied considerably less frequently for German. They are usually listed as one of the valency patterns co-occurring with a relatively small number of verb classes in German reference grammars (cf. Paul 1959; Grundzüge 1980; Zifonun/Hoffmann/Strecker 1997; Duden 2006). The whole variety of verbs co-occurring with the ditransitive pattern is covered only in Wegener's study of the dative in German (cf. Wegener 1985).

In the present contribution, ditransitive and prepositional realisations of the TC in German are studied from a constructionist perspective. The TC is shown to be realised by a variety of different ditransitive and prepositional micro-constructions called "argument structure patterns" (ASPs). These are conceived of as form-meaning pairings which differ only minimally. German micro-constructions will be searched for empirically, using lists of argument realisations of German verbs, valency dictionaries and corpora. Each micro-construction will be studied with respect to the variety of verb classes it co-occurs with, its semantic roles and with respect to the constraints on the range of nominal expressions realising these. The TC is here represented as a family of a large number of different constructions. Previous constructionist approaches have not described the same phenomena in such a fine-grained fashion, representing the TC instead as a single polysemous construction. The analysis chosen allows minimal differences between argument structure patterns to be captured not only within a single language, but also cross-linguistically. Micro-constructions found in German will be used as the basis for a search of corresponding constructions in Romanian. A cross-linguistic comparison of micro-constructions is promising, because claims about the distribution of the TC and the constraints associated with it have so 
far been formulated only with respect to English (cf. Green 1974; Oehrle 1976; Goldberg 1992, 1995).

A German example of the TC is Der Bügermeister überreichte ihm eine Urkunde ('The mayor presented him with a certificate'). In this example, the form [NP-nominative V NP-dative NP-accusative] is paired with the meaning 'Agent causes Recipient to receive Theme', where the NP in the nominative case realises the role of the Agent, the dative NP expresses the role of the Recipient and the NP in the accusative case encodes the role of the Theme, as illustrated below:

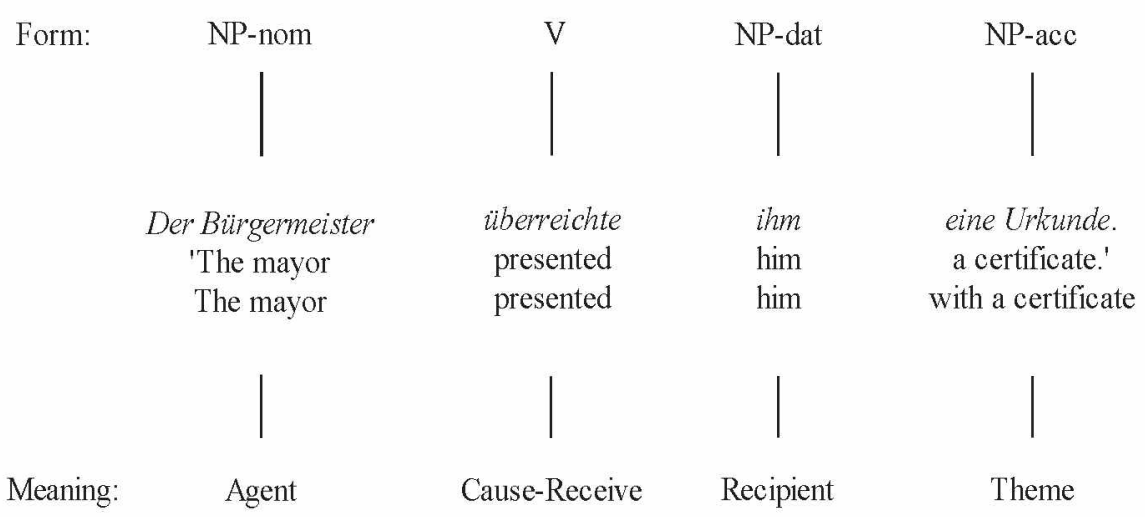

Fig. 1: Transfer construction: Form and semantic roles

Other examples of the TC in German include:2

(1) Eine große Feier plant Lippelt nicht. [Der Stellvertretende Bürgermeister,

$$
\text { the substitute mayor }
$$

Bodo Seidenthal, $]_{\mathrm{NPnom}}[\mathrm{wird}]_{\mathrm{V}}[\text { ihm }]_{\mathrm{NP}-\text { dat }}$ [eine Urkunde $]_{\mathrm{NP}-\text {-ac }}[\text { überreichen }]_{\mathrm{V}}$ Bodo Seidenthal will he.DAT a.ACC.F certificate hand over 'Lippelt is not planning a big party. The substitute Mayor, Bodo Seidenthal, will present him with a certificate.' (Braunschweiger Zeitung, 28.12.2006)

(2)
“..., $[\mathrm{ich}]_{\mathrm{NP}-\text {-nom }}$
[pflück']
pick
$[\mathrm{dir}]_{\mathrm{NP}-\mathrm{dat}}$ you.DAT quickly
[das
Edelweiß] $]_{\mathrm{NP}-\mathrm{accc}}$,
... I will quickly pick the edelweiss for you.' (Hamburger Morgenpost, 19.03.2009)

2 These and all other German examples in this article were selected from the IDS-corpora DEREKo. 
(3) Wenn es so weit kommt, dass das gesellige Trinken aus der Öffentlichkeit if it so far comes that the social drinking from the public sphere verbannt wird, [kann $]_{V}[\mathrm{ich}]_{\mathrm{NP}-\text {-nom }} \quad[\mathrm{mir}]_{\mathrm{NP}-\mathrm{dat}}$ [einen neuen Job $]_{\mathrm{NP}-\text { acc }}$ is banned can I I.DAT a.ACC.M new.ACC.M job $[\text { suchen }]_{\bigvee}, \ldots$

search

'If it should come so far that social drinking is banned from the public sphere, I will have to find myself another job.' (Nürnberger Zeitung, 20.09.2008)

Transfer constructions like those in (1) - (3) are a subclass of the class of double object or ditransitive structures. The latter also comprises benefactive constructions, which may also have the form [NP-nom V NP-dat NP-acc] but pair it with the meaning 'Agent carries out action involving Patient/Theme for the benefit of a Beneficiary' (as in Sally bought John a book). Apart from being realised by a double object pattern, benefactive constructions may also be expressed by a prepositional variant of these (e.g., Sally bought a book for John) as may transfer constructions (see below). In some cases, ditransitive TCs may not easily be distinguished from ditransitive benefactive constructions. This is due to the fact that Recipients may not always easily be distinguished from Beneficiaries. Some Recipients may be considered to be at the same time Beneficiaries, giving rise to a miscellaneous structure, recipient-benefactives, existing alongside pure benefactives and pure TCs. The Recipient in (2) and (3), for example, is at the same time the entity benefitting from the action designated by the main verb. (2) (Ich pflïck' dir schnell das Edel$w e i \beta)$ is most likely to be understood to mean that the Agent will pick the edelweiss with the intention of giving it to the addressee for his/her benefit. An interpretation where the addressee is only the intermediary Recipient and not the Beneficiary is also possible but less likely. (3) (... kann ich mir einen neuen Job suchen) can only be understood to mean that the Agent may have to be looking for a job for him- or herself, i.e. he/she is the Recipient of the entity searched for as well as the Beneficiary of the searching event. Similar considerations apply to Goldberg's example Sally baked her sister a cake, where her sister is both the Recipient of the cake and the Beneficiary of the event of cake-baking. As Goldberg points out, the sentence cannot be understood to mean that Sally baked the cake so that her sister would not have to bake it, that Sally baked the cake as a demonstration of cake-baking or that she baked a cake for herself because her sister wanted her to have one (cf. Goldberg 1995: 141).

Some authors have argued that English lacks purely benefactive ditransitives, the Beneficiary in these structures always being simultaneously a Recipient (cf. Colleman 2010). In other languages, the double object pattern may additionally be used to refer to other types of benefactive events, as exemplified by (4) for French and (5) for German:

$$
\begin{aligned}
& \begin{array}{c}
{[\mathrm{Je}]_{\mathrm{NP}-\text {-subj }}} \\
\mathrm{I}
\end{array} \\
& \text { 'I have ironed his shirt for him.' [example from Colleman 2010: 230] }
\end{aligned}
$$




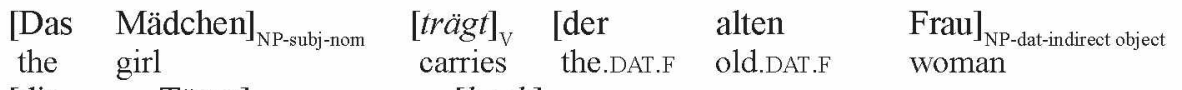

$$
\begin{aligned}
& \begin{array}{cc}
\text { [die Tüten }]_{\text {NP-acc-direct object }} & {[\text { hoch }]_{\mathrm{V} \text {-Particle }}} \\
\text { the.PL.ACC bags } & \text { upstairs }
\end{array} \\
& \text { 'The girl carries the bags upstairs for the old woman.' }
\end{aligned}
$$

The indirect-object-NP in these examples does not express a Recipient-Beneficiary but rather the person who, being the owner of the entity referred to by the direct-object-NP, benefits from the action carried out on his/her property (cf. Allerton 1978: 28; Colleman 2010: 230), and the person benefitting from the Agent's substituting for him/her as the performer of the action (Colleman 2010: 228), respectively. Fellbaum (2005) points out that much of the literature on the benefactive construction in English is based on constructed data. Using data from the World Wide Web, she shows that expressions like Baby open me your door and Honey, can you iron me a shirt?, where the Beneficiary is not at the same time a Recipient, are also attested for English. However, such expressions have received mixed grammaticality judgements in an earlier study (cf. Allerton 1978). Given that German benefactives may be pure benefactives, benefactive constructions should be distinguished from transfer constructions in German. The present study will be confined to transfer constructions, i.e. constructions expressing the notion of a Theme being transferred from one location to another. When the location the Theme is transferred to is a Recipient, the latter may but need not also be a Beneficiary. With respect to double object structures this means that recipient-benefactives will be taken into account as well as pure TCs while pure benefactives as in (5) (Das Mädchen trägt der alten Frau die Tüten hoch) will be excluded. ${ }^{3}$

While transfer constructions differ semantically from benefactive constructions, they differ formally and/or with respect to their meaning or function from caused motion constructions. These are structures involving a PP with to in English or with an ('at') or $z u$ ('to') in German, e.g., John gave an apple to Sally; Ich habe ein Paket an meinen Onkel geschickt ('I sent a package to (literally 'at') my uncle'). The difference between transfer and caused motion constructions will be dealt with in section 5 .

\section{Aims of the present study}

The aim of this study is twofold. Firstly, it investigates the status of the TC as a phenomenon which is partially productive and may therefore be regarded as being situated at the borderline between lexicon and grammar. The partial productivity of the TC has been

3 Double object structures will be taken into account as long as they may be interpreted as being either pure TCs or recipient-benefactives, irrespective of whether they may also be interpreted as pure benefactives in particular contexts (cf. Ich koche dir eine Suppe ('I will cook you a soup') (recipientbenefactive) vs. Ich koche dir eine Suppe, dann können die Kinder davon essen ('I will cook you a soup, so that the children may eat of it') (pure benefactive)). 
extensively described with respect to English, e.g. by Pinker (1989: 110-123), Gropen et al. (1989: 212-216), Goldberg (1992: 50-55, 1995: 31-39), Levin (1993: 45-49) and Boas (2010: 71-74), who showed that TCs (in their terms: ditransitive constructions) combine with verbs of certain classes but not with all verbs which are part of these. Similar observations have been made with respect to Thai by Timyam/Bergen (2010: 159). Adopting the terminology used by these authors, I shall refer to the co-occurrence of the TC with particular verbs as the distribution of this construction.

Apart from being constrained semantically (i.e. in terms of semantic classes), verbs co-occurring with the transfer construction in English have been claimed to be constrained morphophonologically. Green (1974: 79) and Oehrle (1976: 123-125), for example, have argued that verbs which enter into the transfer ("ditransitive" or "double object") construction tend to have native rather than Latinate stems. This constraint has become known as the "Latinate constraint" or the "Latinate restriction". According to Pinker, this constraint applies only to certain verb classes while others appear to be insensitive to it (cf. Pinker 1989: 118-123). Verb classes sensitive to the constraint include verbs of giving (give, pass, hand, ... do enter into the construction, but donate and contribute do not), illocutionary verbs (tell, ask, but not explain, announce, describe, admit, confess, repeat, declare, recount) and verbs of creation (build, cook, sew but not construct, create, design and devise). Verb classes insensitive to the constraint are verbs of future having (bequeath, refer, recommend, guarantee, permit), verbs of future not having (envy, begrudge, deny, refuse) and verbs of instrument of communication (radio, telegraph, telephone, satellite, netmail).

The observation that the relevant double object structures interact with verbs of certain classes is also interesting from a contrastive point of view. It raises the question of whether these constructions combine with verbs of the same classes in different languages. Examples (1) - (3) indicate that this is not necessarily the case: überreichen ('present someone with something'), pflücken ('pick') and suchen ('search') may all be used with the TC in German, but only the English equivalent of the last one may be used in that way. In Romanian, (1) and (3) may be expressed by a double object structure (cf. (1') and (3')), but (2) may only be expressed by a benefactive construction including the preposition pentru ('for') (cf. (2')):

(1') Lippelt nu plănuieşte o petrecere mare.

Lippelt not plan.3sG a party big

Primarul interimar, Bodo Seidenthal, îi va înmâna

mayor.DEF substitute Bodo Seidenthal CL.3SG.DAT AUX.3SG hand over

un certificat.

a certificate

'Lippelt is not planning a big party. The substitute Mayor, Bodo Seidenthal, will present him with a certificate.'

(2') Culeg repede floarea de colț pentru tine. pick.1SG quickly edelweiss.DEF for you.ACC

'I will quickly pick the edelweiss for you.' 
(3') Dacă se ajunge până acolo încât să se interzică ieșitul

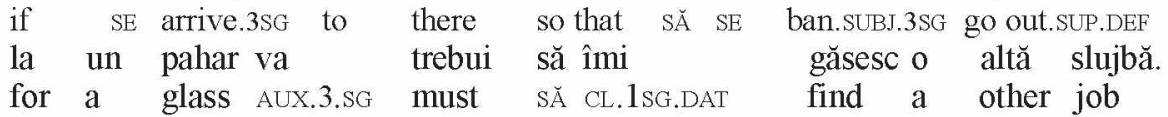
"If it should come so far that social drinking is banned from the public sphere, I will have to find myself another job.'

The Romanian verbs a înmâna ('hand out') and $a$ da ('give') may be used either with a double object pattern or with a PP introduced by pentru ('for'). The use of these verbs with a double object pattern yields a transfer interpretation as in ( 1 '); their combination with a PP with pentru results in a benefactive interpretation of a special kind as in (6):

(6) Am înmânat premiile pentru tine. 'I handed out the prizes for you.' [ = in your place]

An expression like (7) is ambiguous between a transfer reading ('I have handed out your prizes') and a benefactive one ('I have handed out the prizes for you'):

$\begin{array}{lll}\text { ?T,i-am } & \text { înmânat } & \text { premiile. } \\ \text { CL.2SG.DAT-have.1SG } & \text { handed out } & \text { prizes.DEF }\end{array}$

'I have handed out your prizes.' / 'I have handed out the prizes for you.'

The second aim of this study is to explore the question of how the subject-NP and the indirect-object-NP of TCs are constrained. As early as 1965, Partee noticed that the indirect-object-NP in a double object structure must be animate (cf. Partee 1965: 57-62). Green made the same observation and additionally pointed out that the subject-NP must refer to an animate being as well (cf. Green 1974: 103-105). Hence the oddity of expressions like *John brought the table some flowers (inanimate indirect-object-NP; example from Green 1974: 103) and *The sun baked John these cookies (inanimate subject-NP; example from Green 1974: 104).

Both constraints were subsequently reformulated by Goldberg. With respect to the subject-NP, Goldberg claims that it must refer to a volitional Agent rather than to any kind of animate being (cf. Goldberg 1992: 58-61, 1995: 143-146). The volitionality constraint requires not only that the action described by the verb be performed agentively, but also that the relevant transfer be intended. According to Goldberg, Bob told Bill a story can only be understood to mean that Bob had the intention of telling a story to Bill, and not, for example, that Bob told the story to someone else and Bill just happened to overhear. Likewise, Joe painted Sally a picture is understood to mean that Joe intended to give the picture to Sally and not that Joe painted the picture for someone else and later happened to give it to Sally. The effects of the volitionality constraint are also illustrated by the illformedness of the following examples:

(8) *Hal brought his mother a cake since he didn't eat it on the way home.

(9) *Joe took Sam a package by leaving it in his trunk where Sam later found it. (examples and acceptability judgements from Goldberg 1995: 143) 
The notion of volitionality is crucial to the notion of agentivity as are the notions of intentionality and control over an action. An Agent has traditionally been defined as an animate participant who intentionally brings about the situation designated by the verb, situations brought about intentionally being actions (see, among others, the discussion in Primus 2012: 13, 16-20). However, not any kind of action brought about by an Agent is necessarily carried out intentionally or volitionally. Principally, a distinction must be made between Agents which can and such which must have control over the action described by the verb (cf. Primus 2012: 19). Predicates like ermorden ('murder') and betrachten ('scrutinize') are intentional predicates, i.e. intentionality is a necessary component of their meaning and, hence, cannot be cancelled ( ${ }^{*}$ Der Terrorist ermordete den Präsidenten unabsichtlich ('The terrorist accidentally murdered the President'); example from Primus 2012: 13). "\#" is used to indicate that the sentence does not have the intended interpretation, but may be interpreted in some other way which is not relevant to the issue at hand. The sentence The terrorist accidentally murdered the President may be used, for example, by a speaker describing a situation where an Agent intends to murder a particular person, but mistakenly did murder another person (here the President) instead. This issue is also recognized by Goldberg (1995: 143-144), who points out that ditransitives whose subject-NP refers to a non-volitional Agent are well-formed only if the description used to pick out the argument referents may be understood to be the speaker's, not the subject argument's. Thus, Oedipus gave his mother a kiss is felicitous despite the fact that Oedipus did not realise he was kissing his mother, his mother being a description chosen by the speaker. Similarly, Joe gave Mary a sweater with a hole in it is acceptable even if Joe did not intend to give Mary a defective sweater. Goldberg further argues that, for the same reason, it is not necessarily contradictory to use a manner adverb like accidentally in ditransitive expressions (cf. Joe accidentally loaned Bob a lot of money; example Goldberg's).

As opposed to ermorden/murder and betrachten/scrutinize, predicates like töten ('kill') and helfen ('help') do not necessarily express an Agent's intention. When their subject refers to an animate entity, they tend to be interpreted as referring to an intentional action, but they may also be interpreted as referring to an action brought about unintentionally. Hence, these predicates may be combined with adverbs like unabsichtlich or versehentlich / aus Versehen (both 'accidentally') (cf. Opa tötete die Fliege aus Versehen ('Granddad accidentally killed the fly'), example from Primus 2012: 13). The preferred interpretation of sentences with töten and helfen as referring to an intentional action is an implicature; it is not a necessary component of the meaning of these verbs.

The second constraint originally proposed by Green (1974: 103-104) - "animateness of the dative noun phrase" - has been reformulated by Goldberg as a constraint stating that the first object-NP in a ditransitive construction must designate a Beneficiary, or willing Recipient (cf. Goldberg 1992: 61-62, 1995: 147). The requirement that the Recipient be a willing Recipient accounts for why the sentence in (10) is acceptable only under the assumption that Joe is thought to like burnt rice: 
(10) *Sally burned Joe some rice.

(example from Goldberg 1992: 62)

Whenever the referent of the first object cannot be understood to be a willing Recipient, double object structures are not felicitous:

(11) *Bill threw the coma victim a blanket. (example from Goldberg 1992: 62)

The other example Goldberg mentions to illustrate the effect of the relevant constraint is Bill told Mary a story, but she wasn t listening. According to Goldberg (1992: 62), this sentence is infelicitous. I leave it up to English native speakers to decide whether this is indeed the case but would like to observe that the German translation of this sentence (Er erzählte ihr eine Geschichte, aber sie hörte nicht $z u$ ) is perfectly acceptable. On the whole, the sentence in (9) more convincingly illustrates the effects of the constraint on the first object-NP. Its German equivalent (Bill warf dem Koma-Patienten eine Decke zu) is equally infelicitous.

Both constraints have been proposed on the basis of observations made with respect to English TCs. This contribution will explore the question of whether they also hold for the German counterparts of these. The question of how the subject- and first object-NP in TCs are semantically constrained is closely intertwined with the issue of the co-occurrence of that construction with particular verbs. If the construction itself is semantically constrained, it is not surprising that it combines only with verbs which meet the relevant requirements, and not, for example, with non-agentive verbs or with verbs selecting an inanimate NP either as their subject or indirect object.

\section{Previous accounts of the distribution of the transfer construction}

As mentioned above, the distribution of the TC has been studied extensively for English. With the exception of Wegener (1985), studies explicitly dealing with the verb classes co-occurring with the TC in German are lacking. ${ }^{4}$ However, a number of German grammars mention the semantic classes to which ditransitive verbs belong. A comparison of the literature on the verb classes interacting with the TC in English and German shows that some of them co-occur with this construction in both languages. This is true particularly of verbs of giving (give, lend, sell, pass, ...), verbs of directed motion (bring, take, ...), send-verbs (send, post, ...), some types of speech act verbs (especially commissives (promise, guarantee, ...) and information verbs $(t e l l, \ldots)$ ), verbs of future having (leave,

4 Rong (2010) is another exception, but this study is confined to the alternation of the double object construction and its prepositional paraphrases when co-occurring with verbs of change of possession, excluding other verb classes. 
bequeath, ...), verbs of permission (permit, allow, ...), verbs of refusal (refuse, deny, ...), verbs of showing (show, teach, ...), verbs of creation (bake, build, ...), and verbs of obtaining (get, grab, win, steal, ...) (cf. Green 1974: 80-81; Pinker 1989: 110-113; Gropen et al. 1989: 243-244; Levin 1993: 45-48; Goldberg 1992, 1995, 1998; Croft 2003: 55 for English; and Paul 1959: 390-391; Grundzüge 1981: 357-360; Wegener 1985: 263-268; Zifonun/Hoffmann/Strecker 1997: 1308-1311 and Duden 2006: 400-401 for German).

In addition to the verbs common to TCs in English and German, the following verbs have been shown to co-occur with the TC in English: carry-verbs (carry, drag, ...) (cf. Green 1974; Levin 1993), slide-verbs (slide, float, roll, shove, ...) (cf. Green 1974; Levin 1993), verbs of instrument of communication (radio, mail, ...) (cf. Green 1974; Pinker 1989; Gropen et al. 1989; Levin 1993), verbs of throwing (throw, toss, flip, ...) (cf. Green 1974; Pinker 1989; Gropen et al. 1989; Levin 1993; Goldberg 1992, 1995, 1998), dubverbs (baptize, call, christen, ...), declare-verbs (adjudge, assume, believe, ...), appointverbs (acknowledge, adopt, appoint, ...) and bill-verbs (bet, bill, charge, ...) (all mentioned in Levin 1993), and verbs of costing (cost, set back, ...) (cf. Croft 2003).

The following verb classes are additionally mentioned as co-occurring with the TC in German: directives (raten ('advise'), vorschlagen ('propose'), ...) (cf. Paul 1959; Duden 2006), verbs of taking (nehmen ('take'), stehlen ('steal'), entziehen ('withdraw something from someone'), entwenden ('purloin something from someone'), ...) (cf. Paul 1959; Grundzüge 1980; Wegener 1985; Zifonun/Hoffmann/Strecker 1997; Duden 2006), verbs of removal (entfernen ('remove'), amputieren ('amputate'), ...) (cf. Wegener 1985), verbs of not-taking (lassen ('let'), erlassen ('remit'), ...) (cf. Paul 1959; Wegener 1985), verbs of not-giving (schulden ('owe')) (Wegener 1985; Zifonun/Hoffmann/Strecker 1997; Duden 2006), and verbs of concealing (verheimlichen ('conceal'), verbergen ('hide'), ...) (Paul 1959; Grundzïge 1981; Wegener 1985; Zifonun/Hoffmann/Strecker 1997; Duden 2006).

Because of limitations of space, the studies mentioned for English and German cannot be dealt with separately. Tables 1 and 2 summarize their findings regarding the distribution of the TC in English and German respectively. (In tables 1 and 2, "+" indicates that the relevant publication mentions the verb class in question as co-occurring with the TC; "-" indicates that the relevant publication does not mention the verb class in question as co-occurring with the TC; " \pm " indicates that the relevant publication does not explicitly mention the verb class in question as co-occurring with the TCs; in the latter case, the verb class listed may be understood to be included in another verb class, e.g., commissives in the class of verbs of future having.) 


\begin{tabular}{|c|c|c|c|c|c|}
\hline Verb Class & $\begin{array}{l}\text { Green } \\
(1974)\end{array}$ & $\begin{array}{l}\text { Pinker et } \\
\text { al. (1989) }\end{array}$ & $\begin{array}{l}\text { Levin } \\
(1993)\end{array}$ & $\begin{array}{c}\text { Goldberg } \\
(1992,1995,1998)\end{array}$ & $\begin{array}{c}\text { Croft } \\
(2003)^{*}\end{array}$ \\
\hline $\begin{array}{l}\text { 1. verbs of giving (give, } \\
\text { sell, lend, ...) }\end{array}$ & + & + & + & + & + \\
\hline $\begin{array}{l}\text { 2. verbs of directed motion } \\
(\text { bring, take }, . .)\end{array}$ & + & + & + & + & + \\
\hline $\begin{array}{l}\text { 3. carry-verbs (carry, } \\
\text { drag, haul, ...) }\end{array}$ & + & - & + & - & - \\
\hline $\begin{array}{l}\text { 4. send-verbs (send, post, } \\
\text { forward,...) }\end{array}$ & + & + & + & \pm & - \\
\hline $\begin{array}{l}\text { 5. slide-verbs (slide, float, } \\
\text { roll ,...) }\end{array}$ & + & - & + & - & - \\
\hline $\begin{array}{l}\text { 6. verbs of communicated } \\
\text { message }(\text { tell, ask, .. })\end{array}$ & + & + & + & + & - \\
\hline $\begin{array}{l}\text { 7. verbs of instrument of } \\
\text { communication (radio, } \\
\text { mail,...) }\end{array}$ & + & + & + & - & - \\
\hline $\begin{array}{l}\text { 8. commissives (promise, } \\
\text { guarantee, ...) }\end{array}$ & + & + & + & + & + \\
\hline $\begin{array}{l}\text { 9. verbs of future having } \\
\text { (leave, bequeath ...) }\end{array}$ & + & + & + & + & + \\
\hline $\begin{array}{l}\text { 10. verbs of throwing } \\
(\text { throw, toss, flip }, \ldots)\end{array}$ & + & + & + & + & - \\
\hline $\begin{array}{l}\text { 11. verbs of permission } \\
\text { (permit, allow) }\end{array}$ & + & \pm & - & + & + \\
\hline $\begin{array}{l}\text { 12. verbs of refusal } \\
\text { (refuse, deny, forbid) }\end{array}$ & + & + & + & + & + \\
\hline $\begin{array}{l}\text { 13. verbs of showing } \\
(\text { show, teach ,...) }\end{array}$ & + & + & + & + & - \\
\hline $\begin{array}{l}\text { 14. verbs of creation } \\
(\text { bake, cook, sew, ...) }\end{array}$ & - & + & - & + & + \\
\hline $\begin{array}{l}\text { 15. verbs of obtaining } \\
(\text { obtain, get, grab, ...) }\end{array}$ & - & + & - & + & + \\
\hline $\begin{array}{l}\text { 16. bill-verbs (bet, bill, } \\
\text { charge, ...) }\end{array}$ & - & - & + & - & - \\
\hline $\begin{array}{l}\text { 17. appoint-verbs (ack- } \\
\text { nowledge, adopt, appoint, } \\
\text { (.) }\end{array}$ & - & - & + & - & - \\
\hline $\begin{array}{l}\text { 18. declare-verbs (ad- } \\
\text { judge, assure, believe, ...) }\end{array}$ & - & - & + & - & - \\
\hline $\begin{array}{l}\text { 19. dub-verbs (baptize, } \\
\text { christen, ...) }\end{array}$ & - & - & + & - & - \\
\hline $\begin{array}{l}20 . \text { verbs of costing (cost, } \\
\text { set back, ...) }\end{array}$ & - & - & - & - & + \\
\hline
\end{tabular}

Table 1: Verb classes listed by various authors as co-occurring with the TC in English ( ${ }^{*}$ Croft adopts Goldberg's classification, adding only verbs of costing.) 


\begin{tabular}{|c|c|c|c|c|c|}
\hline Verb Class & \begin{tabular}{|c|} 
Paul \\
$(1959)$
\end{tabular} & $\begin{array}{l}\text { Grundzüge } \\
\text { (1981) }\end{array}$ & $\begin{array}{l}\text { Wegener } \\
(1985)\end{array}$ & $\begin{array}{c}\text { Zifonun/ } \\
\text { Hoffmann/ } \\
\text { Strecker } \\
\text { (1997) }\end{array}$ & $\begin{array}{l}\text { Duden } \\
(2006)\end{array}$ \\
\hline $\begin{array}{l}\text { 1. verbs of giving (geben } \\
\text { 'give', spenden 'donate', } \\
\text { leihen 'lend', ...) }\end{array}$ & + & + & + & + & + \\
\hline $\begin{array}{l}\text { 2. verbs of directed motion } \\
\text { (bringen 'bring', liefern } \\
\text { 'deliver') }\end{array}$ & + & - & + & + & \pm \\
\hline $\begin{array}{l}\text { 3. send-verbs (schicken } \\
\text { 'send', senden 'send', ...) }\end{array}$ & + & + & + & + & \pm \\
\hline $\begin{array}{l}\text { 4. information verbs } \\
\text { (mitteilen 'inform', sagen } \\
\text { 'say',...) }\end{array}$ & - & + & + & + & + \\
\hline $\begin{array}{l}\text { 5. commissives (verspre- } \\
\text { chen 'promise', anbieten } \\
\text { 'offer', ...) }\end{array}$ & - & - & - & - & + \\
\hline $\begin{array}{l}\text { 6. directives (raten 'advise', } \\
\text { vorschlagen 'propose', ...) }\end{array}$ & $\begin{array}{c}+ \\
\text { (only } \\
\text { raten) }\end{array}$ & - & - & - & + \\
\hline $\begin{array}{l}\text { 7. verbs of future having } \\
\text { (vererben 'bequeath', } \\
\text { überlassen 'leave', ...) }\end{array}$ & + & + & $\begin{array}{c}+ \\
\text { (only } \\
\text { vererben) }\end{array}$ & + & $\begin{array}{c}+ \\
\text { (only } \\
\text { uberlas- } \\
\text { sen) }\end{array}$ \\
\hline $\begin{array}{l}\text { 8. verbs of permission } \\
\text { (erlauben 'allow'/"permit', } \\
\ldots \text { ) }\end{array}$ & + & - & - & - & + \\
\hline $\begin{array}{l}\text { 9. verbs of refusal (verwei- } \\
\text { gern'refuse',...) }\end{array}$ & + & - & + & - & + \\
\hline $\begin{array}{l}\text { 10. verbs of showing (zeigen } \\
\text { 'show', demonstrieren } \\
\text { 'demonstrate',...) }\end{array}$ & \begin{tabular}{|c|}
+ \\
(only \\
zeigen) \\
\end{tabular} & - & $\begin{array}{c}+ \\
\text { (only } \\
\text { zeigen) }\end{array}$ & - & + \\
\hline $\begin{array}{l}\text { 11. verbs of creation } \\
\text { (stricken 'knit', bauen } \\
\text { 'build', ...) }\end{array}$ & - & - & + & - & - \\
\hline $\begin{array}{l}\text { 12. verbs of obtaining } \\
\text { (besorgen 'get'/\%obtain', } \\
\text { kaufen 'buy', ...) }\end{array}$ & - & - & + & \pm & \pm \\
\hline $\begin{array}{l}\text { 13. verbs of taking (nehmen } \\
\text { 'take', borgen 'borrow', ...) }\end{array}$ & + & + & + & + & + \\
\hline $\begin{array}{l}\text { 14. verbs of removal } \\
\text { (entfernen 'remove', } \\
\text { amputieren 'amputate', ...) }\end{array}$ & - & - & + & - & - \\
\hline
\end{tabular}




\begin{tabular}{|l|c|c|c|c|c|}
\hline $\begin{array}{l}\text { 15. verbs of not-taking (las- } \\
\text { sen 'let', erlassen 'remit', }\end{array}$ & + & - & + & - & - \\
\hline $\begin{array}{l}\text { 16. verbs of not-giving } \\
\text { (schulden 'owe') }\end{array}$ & - & - & + & + & + \\
\hline $\begin{array}{l}\text { 17. verbs of concealing } \\
\text { (verheimlichen'conceal', } \\
\text { verbergen 'hide', ..) }\end{array}$ & + & $\begin{array}{c}+ \\
\text { (only ver- } \\
\text { schweigen) }\end{array}$ & + & $\begin{array}{c}+ \\
\text { (only } \\
\text { verbergen })\end{array}$ & + \\
\hline
\end{tabular}

Table 2: Verb classes listed by various authors as co-occurring with the TC in German

\section{Argument structure patterns and family relationships}

Goldberg (1992: 50-58, 1995: 31-39) argues that the different senses of the transfer construction - in her terms: the "ditransitive construction" - are related to the central sense of actual successful transfer by means of polysemy links. She considers the sense 'Agent successfully causes Recipient to receive Patient/Theme' to be the central sense, because (i) it involves concrete rather than metaphorical or abstract transfer, and concrete meanings have been shown to be more basic diachronically, (ii) it is the sense metaphorical extensions are based on, and (iii) other classes of meanings can be represented most economically as extensions from this sense (cf. Goldberg 1995: 33). The central sense is exemplified by sentences including verbs of giving (Hanna passed Martin the salt), verbs of instantaneous causation of ballistic motion (Pat kicked Chris the ball) and verbs of continuous causation in a deictically specified direction (I brought him his lunch). Goldberg distinguishes the following five extensions of the central sense:

(i) 'Conditions of satisfaction [in the sense of Searle 1983: 10] imply that Agent causes Recipient to receive Patient'. TCs with this sense interact with verbs of giving with associated satisfaction conditions (guarantee, promise, owe, ...) as in Bill promised his son a car (Goldberg 1995: 32),

(ii) 'Agent causes Recipient not to receive Patient'. Variants of the TC with this sense involve verbs of refusal (refuse, deny) as in Joe refused Bob a raise in salary (Goldberg 1995: 32),

(iii) 'Agent acts to cause Recipient to receive Patient at some future point in time'. TCs with this sense contain verbs of future transfer (leave, bequeath, allocate, reserve, grant, ...) as in She bequeathed him her art collection (example from Croft 2003: 50),

(iv) 'Agent enables Recipient to receive Patient'. Variants of the TC with this sense interact with verbs of permission (permit, allow) as in Joe allowed Billy a popsicle (Goldberg 1995: 32), and

(v) 'Agent intends to cause Recipient to receive Patient'. Constructions with this sense contain verbs of creation (bake, make, build, cook, sew, ...) as in Chris baked Jan a cake and Joe painted Sally a picture (both examples from Goldberg 1995: 143) 
or verbs of obtaining (get, grab, win, earn, ...) as in Chris bought him some food (Goldberg 1992: 41).

Since Goldberg explicitly argues that senses (i)-(v) are extensions of the central sense related to it by means of polysemy links, it is clear that she considers combinations of the form [NP-nom V NP-dat NP-acc] with one of these senses as variants of a single ditransitive construction combining that form with the central sense of actual successful transfer. It is therefore surprising that she also refers to pairings of the ditransitive pattern and one of the senses (i)-(v) as minimally different constructions:

Each of the extensions constitutes a minimally different construction, motivated by the central sense; that is, each sense can be represented by a construction that is minimally different from that of the central sense. The semantic relations are captured by $\mathrm{I}_{\mathrm{p}}$-Links [Inheritance by Polysemy-Links], and all information about syntactic specifications is inherited from the central sense. (Goldberg 1995: 76)

As pointed out by Engelberg et al. (2011: 76), Goldberg's conception of constructional polysemy is contradictory, because one and the same partially idiosyncratic form-meaning pair is at the same time regarded as a sense of a single polysemous construction and as a construction of its own which is homonymous with other constructions.

Inconsistencies in Goldberg's conception of constructional polysemy also arise from the assumed parallelism between lexical constructions (constructions consisting of morphologically simple or complex words) and syntactic constructions (syntactic patterns) (cf. ibid. 76-77). Words are regarded as syntactically simple constructions and syntactic patterns as syntactically complex constructions (cf. Croft 2007: 470-471). Since Construction Grammar does not assume a strict division between the lexicon and syntax, lexical constructions and syntactic constructions are viewed as essentially the same type of data structure. Both are regarded as linguistic signs pairing a particular form with a particular meaning and / or function. Goldberg argues that, since lexical and syntactic constructions are basically the same type of data and lexical polysemy is known to be frequent, constructional polysemy is expected (Goldberg 1995: 31-32). Goldberg's discussion of the senses of the ditransitive construction shows that she allows a construction to vary in meaning but not in form. One form associated with different meanings is considered a single polysemous construction, while different forms associated with identical or similar meanings are regarded as synonymous, i.e. different, constructions. This conception of what constitutes the identity of constructions applies to lexical constructions, which are regarded as synonyms, i.e. as two separate lexical items, when they have different forms but are identical or at least similar in meaning as, for example, start and begin. However, synonymous syntactic constructions differ from synonymous lexical constructions in that they often differ only minimally in form. The constructions in (12), for example, which essentially have the same meaning (' $X$ tries to obtain $Z$ in $Y$ '), differ only with respect to the preposition used (nach ('after') vs. auf ('on')): 


$$
\begin{array}{llllll}
\text { Sie } & \text { durchsuchten } & \text { Reisende } & \text { nach } & \text { verdächtigen } & \text { Waren. } \\
\text { they } & \text { searched } & \text { travellers.ACC } & \text { after } & \text { suspicious.PL.DAT goods.D }
\end{array}
$$
'They searched travellers for suspicious goods.'

$\begin{array}{lllll}\text { Sie durchsuchten } & \begin{array}{l}\text { Reisende } \\ \text { travellers.ACC }\end{array} & \text { auf on } & \text { verdächtige } & \text { Waren. } \\ \text { they searched } & \text { suspicious.PL.ACC } & \text { goods.ACC } \\ \text { 'They searched travellers for suspicious goods'. } & & \end{array}$

Goldberg's conception of what makes up the identity of constructions forces us to treat (12a) and (12b) as different constructions. However, since these forms differ only minimally, it is not clear why they cannot be taken to be formal variants of a single construction.

Apart from the inconsistencies already mentioned, Goldberg's notion of polysemy is problematic, because it assumes the inheritance of semantic features which are in fact mutually exclusive. It is not clear in particular how the feature 'actual successful transfer' may be inherited by ditransitive constructions with the sense "Agent causes Recipient not to receive Patient' associated with variants containing verbs like refuse and deny.

In what follows, the variants of the transfer construction in German will be represented as a network of minimally different constructions related by family relationships rather than polysemy links. Following Engelberg et al. (2011: 78), the notion of family relationships will be conceived of as follows:

\section{Family relationships of argument structure patterns}

Let $R$ be a relation of sufficient similarity regarding the values of a set of attributes $\{\alpha, \beta$, $\gamma, \ldots\}$ and $A$ a set of $n$ argument structure patterns:

$A$ is a family with respect to $R\left(\Im^{A R}\right)$ iff for each subset $A^{S} \subset A$ and its complement set $A^{C} \subset A$ there is at least one pair of argument structure patterns, $a^{s} \in A^{S}$ and $a^{c} \in A^{C}$ which are related by sufficient similarity, $R\left(a^{s}, a^{c}\right)$.

The similarity relationship $\mathrm{R}$ is defined with respect to certain attributes. In the case of the $\mathrm{TC}$, these include the number of the arguments a pattern consists of, the formal properties of the single arguments, the semantic description of the argument structure pattern etc. The definition of family relationships does not specify exactly how similar two argument structure patterns have to be for them to qualify as being sufficiently similar. The degree of similarity between two constructions obviously depends on the number of their shared features but may also depend on the nature of each of these. Semantic similarities may have a larger impact on the degree of similarity of two argument structure patterns than formal similarities or vice versa. Independent studies would be required to show whether this is indeed the case.

In the next section, an argument structure pattern will be regarded as a pattern of its own as long as it fits the following definition of argument structure patterns: 
Argument structure patterns

A combination of linguistic units co-occurring with more than coincidental frequency is an argument structure pattern iff: (i) these units consist of a verbal element and its arguments, (ii) at least one of these units is not characterized by lexical elements but by categorial semantic and/or syntactic specifications, and (iii) at least one formal or semantic aspect of these specifications does not follow from general stipulations of the grammar (syntax/morphology/semantics/pragmatics) or of the lexicon (Engelberg et al. 2011: 81).

The requirement in (i) distinguishes argument structure patterns from other types of patterns, including other types of syntactic patterns, different types of lexical or morphological patterns and idioms. (ii) distinguishes argument structure patterns from syntactic patterns like phrase structures, which do not contain lexemes, on the one hand and from fully specified idiomatic patterns on the other. (iii) reflects the property of unpredictability which is claimed to be the defining characteristic of constructions within the framework of Construction Grammar:

$\mathrm{C}$ is a construction iff def $\mathrm{C}$ is a form-meaning pair $\langle\mathrm{F} i$, $\mathrm{S} i>$ such that some aspect of $\mathrm{F} i$ or some aspect of $\mathrm{S} i$ is not strictly predictable from C's component parts or from other previously established constructions. (Goldberg 1995: 4)

Ditransitive transfer constructions meet the requirements in (i)-(iii), because (i) they consist of a verb and its arguments (an Agent, a Theme and a Recipient), (ii) each slot in the construction may be occupied by a large range of different verbs / nominal expressions rather than specific lexical expressions, and (iii) at least one element of their form or meaning is not predictable from general rules of grammar or lexical regularities. The latter claim will be dealt with in more detail in the next section.

\section{The present study}

\subsection{Design of study and empirical basis}

German TCs were searched for as follows:

- All three-place predicates occurring either with a double object pattern or with a pattern consisting of a subject-NP, an object-NP and a PP were collected from Mater (1971) and E-Valbu. Mater (1971) is a list of German verbs classified according to the number and type of their arguments. E-Valbu is the electronic version of the Valenzwörterbuch deutscher Verben (Valency Dictionary of German Verbs) (cf. Schumacher

5 In one of her subsequent publications, Goldberg extends her definition of constructions to include fully predictable patterns "[...] as long as they occur with sufficient frequency" (Goldberg 2006: 4). This criterion automatically raises the question of exactly how frequent a syntactic pattern has to be for it to qualify as a construction, a question which cannot be answered here. 
et al. 2004, E-Valbu: Das elektronische Valenzwörterbuch deutscher Verben). 104 such three-place predicates were gathered from E-Valbu, while a search in Materyielded 4990 of them. (The reason why so many relevant predicates could be gathered from Mater is that this publication lists many more prefixed verbs than E-Valbu. Verbs like abgeben, dazugeben, draufgeben, durchgeben, zurückgeben, hinzugeben and weitergeben, for example, are all listed separately by Mater while only abgeben is listed in EValbu.) At this stage, three-place predicates were gathered irrespective of whether they may occur as part of the TC.

- Verbs interacting with the TC were selected from the lists based on E-Valbu and Mater.

- Verbs interacting with the TC were classified as belonging to semantic classes.

- Missing members of these classes were added by means of the onomasiological dictionary Dornseiff: Der deutsche Wortschatz nach Sachgruppen.

- The corpora of the IDS were searched to gather all syntactic patterns containing verbs of the relevant semantic classes and conveying the notion of transfer. These searches showed that the notion of transfer may be expressed in German by a variety of different argument structure patterns, the double object pattern being only one of them. In the next section, all argument structure patterns (ASPs) associated with the meaning of transfer will be presented as ASP1-ASP26. My discussion of each of these will focus on the question of whether they may be regarded as ASPs as defined above or, using a more general terminology, as constructions in the sense of partially idiosyncratic pairings of form and meaning.

- Romanian counterparts for each of the ASPs identified for German were searched for. Examples of Romanian ASPs were not selected from a corpus. Since German ASPs were gathered first and Romanian ASPs were searched for on the basis of those which were shown to exist in German, only such ASPs could be captured which exist either in both languages or in German only. Romanian ASPs lacking a German counterpart obviously could not be captured by this procedure. The effort required to set up a close to exhaustive list of Romanian ASPs independently of those found for German would have gone beyond the scope of the present study.

\subsection{Realisations of the TC in German and Romanian}

ASPs realising the TC in German and Romanian belong to one of three groups: (i) ASPs relating to direction of transfer, (ii) ASPs relating to intended future transfer, and (iii) ASPs relating to the permission or prohibition of transfer.

\subsubsection{ASPs relating to direction of transfer}

\subsubsection{ASPs relating to transfer from an Agent to a Recipient}

ASP1 pairs the ditransitive pattern ' $\mathrm{X}_{\mathrm{NP}-\text {-nom }} \mathrm{V} \mathrm{Y}_{\mathrm{NP} \text {-dat }} Z_{\mathrm{NP} \text {-acc }}$ ' with the meaning of actual successful transfer (' $\mathrm{X}$ causes $\mathrm{Y}$ to receive $\mathrm{Z}$ by performing action $\mathrm{V}$ '). From a semantic 
point of view, it is the core pattern of the family of TCs, because it interacts with verbs whose meaning is identical with that of the construction.

ASP1: JEMANDEM/ETWAS ETWAS GEBEN ('give someone/something something') 6

$\mathrm{F}: \mathrm{X}_{\mathrm{NP} \text {-nom }} \mathrm{V} \mathrm{Y}_{\mathrm{NP}-\text { dat }} Z_{\mathrm{NP}-\text { acc }}$

$\mathrm{M}$ : $\mathrm{X}$ causes $\mathrm{Y}$ to receive $\mathrm{Z}$ by performing action $\mathrm{V}$

ASP1 is instantiated by examples like (13):

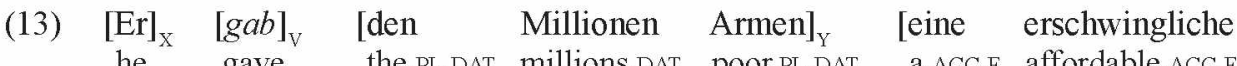
he gave the.PL.DAT millions.DAT poor.PL.DAT a.ACC.F affordable.ACC.F Gesundheitsversorgung und Kleinkredite $]_{Z}, \ldots$

health care and microcredits

'He gave the millions of poor an affordable health care and microcredits.' (dpa, 26.11.2008)

ASPlinteracts with verbs of giving, i.e. verbs which either mean 'give' or whose meaning implies 'give': geben ('give'), abtreten ('cede'), aushändigen ('hand over'), austeilen ('distribute'), bescheren ('give'), hercusrücken ('hand over'), reichen ('pass'), schenken ('give someone something as a present'), spenden ('donate'), spendieren ('get/buy someone something'), stiften ('donate'), überantworten ('entrust'), übereignen ('transfer'), übergeben ('hand over'), überreichen ('hand over'), verschenken ('give as a present'), verteilen ('distribute'), zuschießen ('give someone money'), zustecken ('slip someone something'), zuteilen ('allocate'), zuwenden ('give/bestow'), angedeihen lassen ('provide'), zukommen lassen ('give'), ... Since the arguments of give-verbs have exactly the same roles as those of the TC (Agent, Theme and Recipient), give-verbs and their participant roles may easily fuse with the CAUSE-RECEIVE-predicate and the roles of the construction. However, the following give-verbs do not allow the double object pattern: ausstatten ('equip someone with something'), beglücken ('bless someone with something'), traktieren ('treat someone to something') and versorgen ('to supply someone with something'). Though these verbs fulfil the selection restrictions imposed on the verb by ASP1, they cannot be used with this pattern. The selection restrictions of ASP1 represent a stipulation of the grammar which does not explain the incompatibility of the four verbs mentioned with ASP1. The stipulation is general in that it affects a large number of lexical

6 The pronoun etwas ('something') has been included in the quotation form of ASP1 to account for the fact that, when this pattern co-occurs with geben ('give'), the Recipient may be an entity carrying the features [+animate] and [-human] (e.g., an animal). All other verbs interacting with ASP1 require a [+human] Recipient. Since geben is only marginally involved in the alternation between ASP1 and its prepositional variant ASP3 (ETWAS AN JEMANDEN ÜBERGEBEN ('give something to someone')), ASP3 does not allow for a [-human] Recipient. Hence, the pronoun etwas has not been included in the quotation form of ASP3. In general, the use of the pronoun etwas in the quotation forms of the ASPS does not necessarily indicate inanimateness of the participant in question: etwas may also refer to polysemous expressions like the company which are systematically ambiguous between a buildingreading and a group-of-people reading. 
items, in this case a large number of verbs of giving rather than single words, but not as general in its scope of application as general rules of grammar or lexical regularities. The selection restrictions of ASP1 appear to have the status of a mid-level generalisation. Since this mid-level generalisation does not explain why ASP1 does not combine with ausstatten, beglücken, traktieren and versorgen, ASP1 may be considered an argument structure pattern in the sense outlined in section 4 .

\section{Constraints and metaphorical extensions}

In general, ASP1 appears to be associated with the constraints observed by Goldberg on the subject-NP and the first object-NP: the former must refer to a volitional Agent, while the latter mostly refers to a willing Recipient. In many cases, both constraints are met in a straightforward fashion as, for example, in (13). However, the constraint stating that the first object-NP refers to a willing Recipient is obviously violated by examples containing verbs like aufdrängen, aufzwingen and aufnötigen (all 'force something on someone'), auflasten and aufbürden (both 'burden someone with something'), aufhalsen ('saddle someone with something') and aufbrummen ('land someone with something') as illustrated by (14):

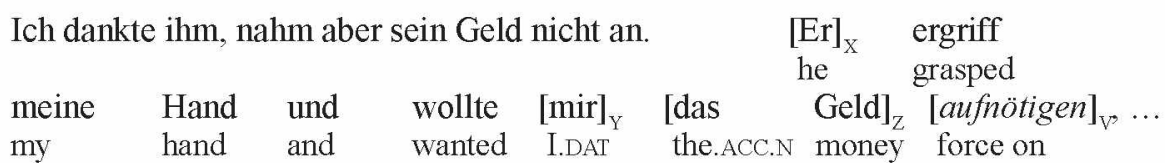

'I thanked him, but did not accept his money. He grasped my hand and wanted to force the money on me, ...' (S. Lenz: Exerzierplatz. Roman, (Erstv. 1981), in: Werkausgabe in Einzelbänden, Bd. 10. Hamburg, 1998 [p. 538])

Other expressions violating the constraints on the subject- and first object-NP appear to involve metaphorical extensions of the meaning of ASP1 ('actual successful transfer' or ' $X$ causes $Y$ to receive $Z$ by performing action V'). Goldberg (1992: 63-66, 1995: 148151) identifies a number of metaphors by which the central sense of actual successful transfer may be extended. All of them use the notion of transfer as their source domain. Examples are (15), (16) and (17) which are licensed by metaphors involving causal events as transfers (15), actions directed at a person as entities transferred to that person (16), and perceptions as entities moving to the perceiver (17). In (15), which is similar to Goldberg's example The tabasco sance gave the baked beans some flovor (Goldberg 1995: 146), an effect caused in an entity is seen as an object transferred to that entity:

(15) Im Dorf Hahn geht es noch beschaulich $\mathrm{zu}$, [etliche landwirtschaftliche in-the village Hahn goes it still tranquil to several agricultural Betriebe $]_{\mathrm{X}}[\text { geben }]_{\mathrm{V}}[\mathrm{ihm}]_{\mathrm{Y}} \quad[$ das typische Flair eines businesses give it.DAT the.ACC.N typical.ACC.N flair a.GEN.M Hunsrïckortes $]_{Z}$. Hunsrück-place.GEN.M 'In the village of Hahn, life is still tranquil, several farms give it the typical flair of a Hunsrück place.' (Rhein-Zeitung, 27.11.2004)

The source domain of the metaphor licensing (15) is the notion of actual successful trans- 
fer (' $\mathrm{X}$ causes $\mathrm{Y}$ to receive $\mathrm{Z}$ '); its target domain is the notion of causation (' $\mathrm{X}$ is the cause of Y being affected by Z'). Though the animateness constraint on the subject-NP and the willing-Recipient-constraint on the first object-NP are not met in the target domain of the metaphor, both constraints are met in its source domain. It is doubtful, however, whether the Recipient in examples like (15) or in Goldberg's own example is also a willing Recipient. Whether this is indeed the case seems to depend on the kind of lexical expression realising the role of the transferred entity (cf. The dilapidated houses give the village an air of decay.).

The metaphor licensing (16) involves understanding actions directed at a person as entities transferred to that person:

(16) Maria sammelte die Scherben auf. Als sie im Fahrstuhl nach oben when they in-the elevator up

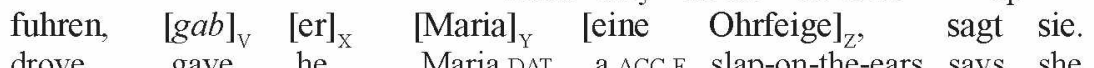
drove gave he Maria.DAT a.ACC.F slap-on-the-ears says she 'Maria collected the broken pieces. When they ascended in the elevator, he gave Maria a slap on the ears, she says.' (Berliner Zeitung, 6.8.2005)

The source domain of the metaphor licensing (16) is the notion of actual successful transfer (' $\mathrm{X}$ causes $\mathrm{Y}$ to receive $\mathrm{Z}$ '), while its target domain is the notion of an action directed at a person (' $X$ performs an action $Z$ directed at $Y$ '). Even if one accepts the idea of expressions like (16) being licensed metaphorically, the requirement that the first object-NP refer to a willing Recipient is not met either in the source or in the target domain of the metaphor. With respect to examples like this one, including Bill gave Chris a headache and Bill gave Chris a kick (Goldberg 1995: 147), Goldberg argues that "In some cases, however, the issue of the recipient's willingness or unwillingness is irrelevant to whether transfer is successful" (ibid.) and that "... all cases in which the first object is required to accept the transferred object in order for transfer to be successful imply that the first object is assumed to be a willing recipient." (ibid.). Though it is true that acceptance of the transferred object is a requirement for transfer to actually take place, it does not follow from this that the Recipient is actually willing to receive the transferred object. Examples like (16) cast doubt on the general validity of the constraint stating that the first object NP in a ditransitive construction must refer to a willing Recipient.

The metaphor underlying (17) involves the comparison of perceptions coming to the awareness of a perceiver with entities moving to that perceiver:

(17) $[\mathrm{Er}]_{\mathrm{X}}$ nahm sie mit ins Universitätsgelände, [zeigte $]_{\mathrm{V}}[\mathrm{ihr}]_{\mathrm{Y}}$ he took she.ACC with into-the university grounds showed she.DAT [die Mensa, die Fakultät, Hörsaal 7, in dem er the.ACC.F dining-hall the.ACC.F faculty lecture room 7 in which he immatrikuliert worden war -- $]_{Z} \cdots$

was enrolled

'He took her to the university grounds, the dining-hall, the faculty, lecture room 7 in which he was enrolled -- ...' (Walser, Martin: Die Verteidigung der Kindheit. Frankfurt a.M., 1991 [p. 39]) 
Here again, the metaphor licensing (17) uses the notion of transfer as its source domain (' $\mathrm{X}$ causes $\mathrm{Y}$ to receive $\mathrm{Z}$ '). Its target domain is the notion of perceptions moving to the perceiver (' $X$ acts to cause $Y$ to see $Z$ ').

A fourth type of metaphor, the conduit metaphor, which involves communication travelling across from a Stimulus (or speaker) to a listener (cf. Reddy 1979), licenses expressions like (18):

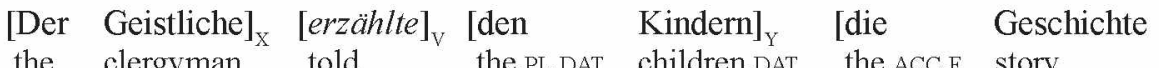

$$
\begin{aligned}
& \text { von } \text { Abraham }_{\mathrm{Z}}, \ldots \\
& \text { of Abraham,... } \\
& \text { 'The clergyman told the children the story of Abraham.' (Rhein-Zeitung, 26.2.2004) }
\end{aligned}
$$

The source domain of the metaphor is the central sense of actual successful transfer (' $\mathrm{X}$ causes $Y$ to receive $Z^{\prime}$ ), its target domain that of a speaker communicating a message to a listener (' $X$ communicates $Z$ to $Y$ '), where $X$ is the referent of the subject-NP (in (15): the clergyman), $Y$ is the referent of the first object-NP (in (15): the children) and $Z$ the referent of the second object-NP (the story of Abraham) (cf. Goldberg 1992: 63, 1995: 148). The conduit metaphor licenses TCs containing verbs of the following classes:

- General verbs of communication: sagen ('say'), but not sprechen ('speak') or sich öußern ('utter')

- Verbs of communication expressing a communication medium: schreiben ('write'), faxen ('fax'), mailen ('mail'), funken ('radio'), vorlesen ('read out'), zitieren ('quote'), However, verbs of communication expressing a manner of communication do not interact with the TC (e.g., flüstern ('whisper'), schreien ('shout'), stottern ('stutter'), ...).

- Verbs of informing: mitteilen ('inform'), beschreiben ('describe/depict'), schildern ('depict'), erzählen ('tell'), übermitteln ('convey'), überbringen ('deliver'), bekanntgeben ('announce'), erklären ('explain'), verdeutlichen ('explain'), verraten ('betray'), voraussagen ('prophesy'), ... However, assertives (behaupten ('claim/assert'), widersprechen ('contradict'), ...) do not interact with the TC nor do other verbs of informing including erinnern ('remind'), berichten ('report'), verlautbaren ('announce'), verbreiten ('spread'), warnen ('warn'), benachrichtigen ('notify'), unterrichten ('inform'), verständigen ('notify'/'inform'), einweihen ('let someone in on a secret'), einführen ('initiate/introduce'), aufdecken ('uncover'), and ausplaudern ('let out'). (See Harras 2007 on the argument structure patterns of assertives and verbs of informing.)

- Directives: raten ('advise'), anraten ('advise someone'), auftragen ('instruct'), beibringen ('teach'), befehlen ('command'), gebieten ('command'), diktieren ('dictate something to someone / impose something on someone'), vorschlagen ('propose'), empfehlen ('recommend'). However, other directives do not interact with the TC (except permission verbs and forbid-verbs which will be discussed below). (See Winkler (2007b) on the argument structure patterns of directives.) The association of permission verbs and forbid-verbs with the ditransitive patterns yields a different argument structure pattern which will be discussed below as ASP13. 
- Expressives: Expressives generally do not interact with the TC. Exceptions are vorwerfen ('reproach') and vorhalten ('reproach'). Other expressives may not be used with the TC except prefixed forms such as abschmeicheln ('get something from someone by flattering him/her') and vorklagen ('complain to someone'). (See Proost 2007 on the argument structure patterns of expressives.)

The conduit metaphor also licenses expressions where the double object pattern interacts with verbs like verheimlichen ('conceal'), verschweigen ('withhold') and verhehlen ('conceal'), which are antonyms of information verbs. ${ }^{7}$ Alternatively, expressions where ASP1 co-occurs with these verbs may be regarded as instances of ASP26, which pairs the double object form with the meaning ' $\mathrm{X}$ causes $\mathrm{Y}$ not to receive $Z$ ' (see below).

ASP1 has an exact counterpart in Romanian which interacts with the same type of verbs (verbs of giving), including a da ('give'), a ceda ('cede'), a înmâna ('hand over'), a vinde ('sell'), a dărui ('to give something as a gift'), a înapoia ('give back'), a impărți ('distribute'), ...:

$$
\begin{array}{llcc}
{[\text { Mihai }]_{\mathrm{X}} \quad[\mathrm{i}-]_{\mathrm{Y}}[\mathrm{a}]_{\mathrm{V}}} & {[d a t]_{\mathrm{V}}} & {[\text { Mariei }]_{\mathrm{Y}}} & {[\text { flori }]_{\mathrm{Z}}} \\
\text { Michael CL.3SG.DAT-have.3SG } & \text { given } & \text { Mary.DAT } & \text { flowers } \\
\text { 'Michael gave Mary flowers.' } & & &
\end{array}
$$

As in German, ASP1 also interacts with verbs of communication and information verbs in Romanian (verbs of communication: a comunica ('communicate'), a spune ('say'), a zice ('tell'), a povesti ('tell a story'), a relata ('report'), a şopti ('whisper to'), a striga ('shout'), a citi ('read out loud'), a cita ('quote') etc.; verbs of informing: a scrie ('write'), a descrie ('depict'), a explica ('explain'), a trăda ('betray') etc.). Exceptions include a anunța ('announce'/"notify'), which takes an accusative and a prepositional object (e.g., i-am anuntat pe copii de schimbarea orei - 'I have notified the children of the change of the hour'). The co-occurrence of ASP1 with Romanian verbs of communication is exemplified by (20):

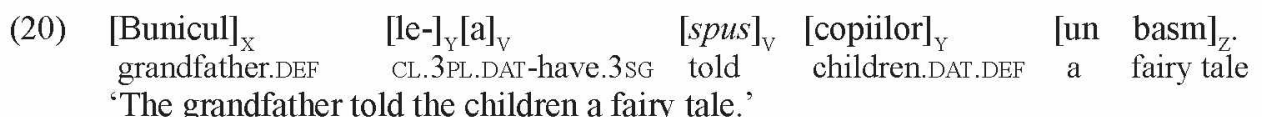

'The grandfather told the children a fairy tale.'

\footnotetext{
Verbs of communication and speech act verbs of course also occur with a variety of other argument structure patterns. A number of these verbs also realise the role of the Listener as a PP headed by vor or gegenuber (both: 'in front of'), while the role of the message transferred may be realised not only as an NP in the accusative case but also by different types of finite or non-finite complement clauses or different types of PPs. All combinations of these different realisations of the role of the Listener (the Recipient) and that of the message transferred (the Theme) would in principle have to be treated as separate argument structure patterns, because they are formally different from ASP1. Semantically, however, they are all metaphorical extensions of the meaning of ASP1 ("X causes Y to receive $\mathrm{Z}$ by performing action $\mathrm{V}^{\prime}$ ). Argument structure patterns interacting with verbs of communication and speech act verbs therefore constitute a sub-family of the family of transfer constructions. Because of limitations of space, this sub-family cannot be discussed here.
} 
As in German, directives in Romanian behave differently as to whether they do or do not allow the double object pattern. While verbs like a comanda ('order'), a ordona ('command'), a dicta ('dictate something to someone/impose something on someone'), a propune ('propose'), and a recomanda ('recommend') are like their German counterparts in that they allow the double object pattern, verbs like a sfătui ('advise') and a învăta ('teach') take two accusative NPs (see ASP2 for a discussion of these and other Romanian verbs taking two accusative object NPs). Like their German counterparts, Romanian expressives generally do not interact with the TC. Exceptions are a reproşa ('reproach') and a imputa ('reproach'), whose German equivalents are also the only expressives allowing the double object pattern.

The Romanian counterpart of ASP1 also co-occurs with verbs like $a$ arăta ('show') as illustrated by (21):

(21) $[\text { Gazda }]_{X}[\mathrm{le}-]_{Y}[\mathrm{a}]_{\mathrm{V}}$ $[\text { arătat }]_{\mathrm{V}}[\text { [oaspeților }]_{\mathrm{Y}}$ [camerele unde vor host.DEF CL.3PL.DAT-have.3SG shown guests.DAT.DEF rooms.DEF where AUX.3PI. dormi la noapte $]_{Z}$. sleep at night

'The host showed the guests the rooms where they will be sleeping tonight.'

On the whole, ASP1 interacts with the same verb classes and shows the same type of metaphorical extensions in German and Romanian.

The second argument structure pattern, ASP2 (JEMANDEN ETWAS LEHREN), may be considered a metaphorical extension of ASP1 licensed by the conduit metaphor, which has been shown to generally license expressions involving the interaction of the double object pattern with speech act verbs. However, argument structure patterns involving lehren formally differ from instances of ASP1 in that they comprise two accusative object NPs. This is due to the fact that lehren realises its Recipient-/Listener-argument as a NP in the accusative rather than the dative case. The interaction of the double accusative object pattern with lehren therefore constitutes an ASP of its own:

ASP2: JEMANDEN ETWAS LEHREN ('teach somebody something')

$\mathrm{F}: \mathrm{X}_{\text {NP-nom }} V Y_{\text {NP-acc }} Z_{\text {NP-acc }}$

$\mathrm{M}$ : $\mathrm{X}$ causes $\mathrm{Y}$ to receive $\mathrm{Z}$ by performing action $\mathrm{V}$

ASP2 is illustrated by (22):

(22) Es klang, als wollte er daran erinnern, [wer $]_{\mathrm{X}}$ [die Amerikaner $]_{\mathrm{Y}}$ it sounded as if wanted he to that remind who the.PL.ACC Americans

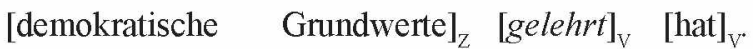
democratic.PL.ACC basic values taught has 'It sounded as if he wanted to remind who taught the Americans basal democratic values.' (Berliner Zeitung, 17.11.2003)

Apart from lehren, there are three other speech act verbs (fragen, abfragen and abhören) which take two objects in the accusative case. The co-occurrence of these verbs with the double object pattern yields an argument structure pattern different from ASP2 (see below 
for discussion). The only other German verb taking two accusative NPs is kosten ('cost'), ${ }^{8}$ whose interaction with the double object pattern does not yield instances of the TC. When ASP2 interacts with lehren ('teach'), it involves a Speaker (the metaphorical Agent), a Listener (the metaphorical Recipient) and a message transferred (the metaphorical Theme)

In Romanian, the set of verbs taking two accusative object-NPs is slightly larger, comprising 10 verbs as opposed to 5 in German. The following Romanian verbs take two accusative object-NPs: a asculta ('listen/examine'), a examina ('examine'), a învăta ('teach'), a sfătui ('advise'), a întreba ('ask a question'), a ruga ('ask someone to do something'), a trece ('pass'), a traversa ('to cross'), a vesti ('inform') and a anunta ('announce'). The co-occurrence of a învăța ('teach'), a sfătui ('advise'), a ruga ('ask someone to do something'), a vesti ('inform') and a anunta ('announce') with two accusative object-NPs yields instances of ASP2, which involve a Speaker (or Agent), a Listener (or Recipient) and a transferred message (or Theme) as in (23):

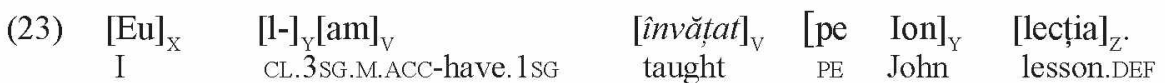
'I have taught John the lesson.'

For a discussion of the syntactic and semantic properties of Romanian double accusative object structures, see Tigău (this volume).

The third argument structure pattern, ASP3, shares its meaning, the central meaning of actual successful transfer, with ASP1 but differs formally from the latter in that (i) it realises the Recipient as a PP, not as an NP, and (ii) the constituent realising the role of the Theme/ Patient precedes rather than follows the constituent realising the role of the Recipient.

ASP3: ETWAS AN JEMANDEN ÜBERGEBEN ('hand over something to somebody')

F: $\mathrm{X}_{\mathrm{NP} \text {-nom }} \mathrm{VZ}_{\mathrm{NP}-\mathrm{acc}} \mathrm{Y}_{\mathrm{PPan}}$

$\mathrm{M}$ : $\mathrm{X}$ causes $\mathrm{Y}$ to receive $\mathrm{Z}$ by performing action $\mathrm{V}$

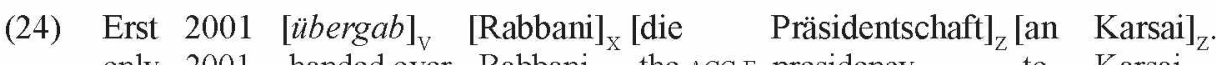
only 2001 handed over Rabbani the.ACC.F presidency to Karsai 'Only in 2001 did Rabbani hand over the presidency to Karsai.' (Die Rheinpfalz, 11.10.2010)

Though ASP3 may in principle combine with verbs of giving, a large number of these do not allow the pattern. This is true, for example, of bescheren ('give'), herausrücken

8 Zifonun/Hoffmann/Strecker (1997: 1311-1312) mention lehren ('teach'), abhören ('test somebody') and abfragen ('test somebody') as verbs taking two accusative object-NPs. Duden (2006: 934-936) mentions fragen ('ask') and kosten ('cost') in addition to these. Both publications point out that the first NP following these verbs is increasingly being replaced by a dative NP in colloquial speech. Fragen only rarely realises the role of the propositional content as an accusative NP. When the propositional content is expressed in that way, the accusative NP is a pronoun (cf. Ich frage ihn das/etwas/ nichts vs. *Ich frage ihn den Weg ('I ask him that/something/nothing' vs. 'I ask him the way')). 
('hand over'), reichen ('pass'), schenken ('give something as a present'), zustecken ('slip someone something'), zuwenden ('give/bestow') and angedeihen lassen ('provide'). The use of geben ('give') with ASP3 is possible but very unusual. In a random search of all written IDS-corpora for patterns consisting of the verb geben, an NP realising the Themeargument and an NP or PP realising the Recipient argument, the Recipient argument proved to be realised as a PP (headed by an) only in one out of 100 occurrences of that pattern. The fact that the give-verbs mentioned may not be used with ASP3, while giveverbs generally do, indicates that ASP3 is at least partially unpredictable. All other giveverbs which occur with ASP1 also interact with ASP3 and hence show the dative alternation. These verbs include abtreten ('cede'), aushändigen ('hand over'), austeilen ('distribute'), spenden ('donate'), spendieren ('get/buy someone something'), stiften ('donate'), überantworten ('entrust'), übereignen ('transfer'), übergeben ('hand over'), überreichen ('hand over'), verschenken ('give as a present'), verteilen ('distribute'), zuschießen ('give someone money'), zuteilen ('allocate'), zukommen lassen ('give'). In addition to verbs of giving, verbs of communication expressing a communication medium, which have been shown to interact with ASP1, also co-occur with ASP3.

It has often been argued in the literature on the double object construction that constructions consisting of an NP followed by a PP differ semantically from their corresponding double object constructions (henceforth: DOCs) in that they express the notion of forced motion along a path. As opposed to the prepositional patterns, DOCs, as we have seen, are claimed to encode the notion of transfer from an Agent to a Recipient. Because of this semantic difference, the prepositional patterns are often referred to as "caused motion constructions" (cf. Timyam/Bergen 2010), or more specifically, as "transfer caused motion constructions" (cf. Goldberg 1995: 89-97) in much of the literature on Construction Grammar $(\mathrm{C} \& \mathrm{G})$. Thus, the main semantic difference between the two types of construction would appear to be that the first object-NP of the DOC is a Recipient whereas the same argument (the NP embedded in the PP of the prepositional variant) is a Goal. Correspondingly, the semantic paraphrases proposed for the prepositional pattern and the DOC are ' $\mathrm{X}$ causes $\mathrm{Z}$ to go to $\mathrm{Y}$ ' (caused motion meaning) and ' $\mathrm{X}$ causes $\mathrm{Y}$ to receive $Z$ ' (caused possession meaning), respectively.

Taking up an example introduced by Green (1974: 157), Pinker (1989: 82-83) argues that teaching the students French implies that the teaching was successful (i.e. the students got to know some French) while teaching French to the students does not have that implication. Likewise, Pinker claims that " $\ldots$ it would be odd to say I told John the news if John were deaf or dead, whereas I told the news to John may be a bit less anomalous in those circumstances." In much the same way, Goldberg (1992: 51-52) argues that Mary showed her mother a photograph implies that Mary's mother actually saw the photograph whereas for many speakers no such implication is present in Mary showed the photograph to her mother. Hence, the latter but not the former may be continued by but her near-sighted mother couldn't see it. The view that the double object pattern is necessarily associated with a caused possession meaning, while the prepositional variant is always 
associated with a caused motion meaning is now the predominant view among semanticists. It has been contradicted, however, by Levin/Rappaport Hovav (2005: 210, 216219) and Rappaport Hovav/Levin (2008), who argue that verbs like give and sell only have a caused possession meaning, while verbs like throw and send have both caused motion and caused possession meanings.

Similar semantic differences between DOCs and their prepositional paraphrases have been claimed to hold for German. According to Wegener (1985: 224), the animate referent of the NP in a PP headed by $a n$ ('to') or $z u$ ('to') is an Addressee as opposed to the referent of the first object-NP in a DOC, which she claims to be a Recipient. Thus Wegener uses "Recipient" to refer to the entity actually receiving the transferred entity and "Addressee" to refer to the entity at which the transfer action is directed. Following Eroms (1978: 405), Wegener argues that this semantic difference is confirmed by the bekommen-passivisationtest: Only DOCs allow passivisation by means of bekommen ('receive'); prepositional patterns lacking a DOC-variant cannot be passivised in this way, cf:

$\begin{array}{llllll}\text { (25a) Hans bekommt (von } & \text { Otto) die } & \text { Wohnung vermietet. } \\ \text { Hans receives (by } & \text { Otto) the.ACC.F flat } & \text { let }\end{array}$ (active: Otto vermietet Hans die Wohnung / Otto vermietet die Wohnung an Hans.) 'Hans has been let the flat (by Otto).'

(25b) *Anna bekommt (von Otto) ein Paket abgeschickt. Anna receives (by Otto) a.ACC.N package sent off (active: Otto schickt ein Paket an Anna ab. / *tto schickt Anna das Paket ab.) *'Anna has been sent off a package (by Otto).'

Wegener's examples include the expression eine Bitte an jemanden richten (lit.: 'direct a request to someone'; Engl.: 'to make a request to someone') and sentences containing the verbs verschenken ('give as a present') and abschicken ('send off'). According to Wegener, these verbal expressions require the addressee to be realised by a PP headed by $a n$ ('to') and do not occur in a DOC (cf. Otto hat das Paket an Anna abgeschickt/verschenkt vs. *Otto hat Anna das Paket abgeschickt/verschenkt; Otto hat eine Bitte an Anna gerichtet / Otto hat Anna eine Bitte gerichtet. Acceptability judgements are Wegener's.). However, the validity of Wegener's evidence from bekommen-passivisation may be questioned because of four reasons. Firstly, eine Bitte an jemanden richten is a fixed expression which may resist passivisation (and other syntactic operations), because it has become frozen in a particular form. Secondly, the co-occurrence of verschenken with the double object pattern is attested in the IDS-corpora, as shown by (26) and (27):

(26) $\ldots,[\text { der schwedische Botschafter in Berlin }]_{\mathrm{X}}[\text { verschenkt }]_{\mathrm{V}} \quad[$ seinen the Swedish ambassador in Berlin gives as a present his.PL.DAT Gästen] $]_{\mathrm{Y}}$ ohne Scham [ein Kochbuch mit den 50 Klassikern aus guests.DAT without shame a.ACC.N cook book with the 50 classics from Schweden $]_{Z}$.

Sweden

'The Swedish ambassador in Berlin shamelessly gives his guests a cook book with the 50 classical recipes of Sweden, as a present.' (Mannheimer Morgen, 14.1.2006) 


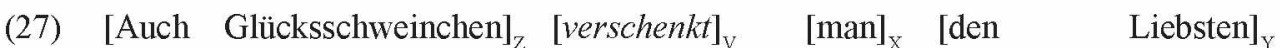
also little good-luck pigs gives as a present one the.PL.DAT sweethearts zur Jahreswende nach wie vor gerne. at-the turn of the year as of old with pleasure 'As of old, one also likes to give one's sweethearts good-luck pigs at the turn of the year.' (Rhein-Zeitung, 31.12.2007)

The fact that a verb like verschenken, which does occur with the DOC as well as the prepositional pattern, may not be used in a sentence passivised by bekommen in fact shows that the impossibility of bekommen-passivisation does not necessarily preclude the possibility that the corresponding active sentence may be either a DOC or a prepositional pattern, cf.:

(25c) *Anna bekommt (von Otto) ein Paket verschenkt.
Anna receives (by Otto) a.ACC.N package given as a present
(active: Otto verschenkt Anna ein Paket. / Otto verschenkt ein Paket an Anna.)
'Anna has been given a package as a present (by Otto).'

This possibility, which is not discussed by Wegener, shows that bekommen-passivisation may not reliably be used to test whether the animate goal of a transfer action is a Recipient or an Addressee/a Goal. Thirdly, verbs prefixed by $a b$ - (abschicken ('send off'), $a b$ senden ('send off'), etc.), which do seem to be restricted to co-occur with a prepositional pattern, also resist bekommen-passivisation, as pointed out by Wegener. However, these verbs are likely to be incompatible with sentences containing an expression like bekommen ('receive') for independent reasons: They refer to the onset of a transfer action while bekommen refers to the end point of such actions. Hence, verbs like abschicken and $a b-$ senden are semantically incompatible with an expression like bekommen. The bekommen-passivisation test does not actually prove that the transfer action expressed by a DOC is necessarily successful. Fourthly, bekommen-passivisation presupposes raising of a dative NP (cf. Zifonun/Hoffmann/Strecker 1997: 1827). Hence, verbs which do not take a dative NP such as abschicken in (22b) do not allow bekommen-passivisation in principle. This is a syntactic regularity which is independent of the question of whether or not the transfer action expressed by the verb is successful.

Evidence from inference patterns in fact contradicts the assumption that the referent of the first object-NP in a DOC in German is generally a Recipient while the referent of an NP embedded in the PP of a prepositional pattern is generally a Goal. Whether the relevant NP realises the role of a Recipient or the role of an Addressee seems to depend on the type of verb DOCs and prepositional patterns interact with. Both types of construction entail the notion of actual and successful transfer when they co-occur with give-verbs. Thus, expressions built on either type of construction may not be continued by a clause cancelling the implication of transfer actually having taken place when they contain a verb like give:

(28a) 'Ich habe dem Hausmeister den Schlüssel $\begin{aligned} & \text { übergeben, aber er } \\ & \text { I have the.DAT caretaker the.ACC key }\end{aligned}$
hat ihner but he
has nicht bekommen.
"I gave the caretaker the key, but he never received it.'


(28b) 'Ich habe den Schlüssel an den Hausmeister übergeben, aber er I have the.ACC key to the.ACC caretaker handed over but he hat ihn nie bekommen.

has it.ACC never received

${ }^{26}$ I gave the key to the caretaker, but he never received it.'

(28a) and (28b) are both infelicitous, because the verb ïbergeben ('hand over') itself entails the notion of actual and successful transfer. Hence, it cannot be combined with a clause cancelling this entailment.

However, when DOCs and prepositional patterns (ASP1 and ASP3) interact with verbs expressing a communication medium, they do not necessarily imply the notion of actual and successful transfer. As opposed to the sentences in (28), expressions built on either type of construction may be continued by a clause cancelling the implication of actual and successful transfer when they contain a verb expressing a communication medium:

(29a) Anna hat dem Direktor einen Brief geschrieben, der aber

Anna has the.DAT.M director a.ACC.M letter written which however

nie angekommen ist.

never arrived is

'Anna wrote the director a letter, which, however, never arrived.'

(29b) Anna hat einen Brief an den Direktor geschrieben, der Anna has a.ACC.M letter to the.ACC.M director written which aber nie angekommen ist however never arrived is

'Anna wrote a letter to the director, which, however, never arrived.'

The fact that (29a) is neither more nor less well-formed than (29b) indicates that neither DOCs nor their prepositional variants necessarily imply the notion of actual and successful transfer. The difference in meaning between the two structures - if indeed there is any - is likely to be due either to pragmatic factors such as discourse function (cf. ErteschikShir 1979) or information structure (cf. Timyam/Bergen 2010) or to semantic factors such as the definiteness or indefiniteness of the NPs (cf. Allerton 1978) or the type of Recipient expressed (institution vs. person; cf. Dürscheid 1999: 210-213). This assumption is in line with the observation made by Pinker, one of the main proponents of the "two constructions / two meanings hypothesis", that "... the intuition of a semantic change [caused by the dative alternation] can be rather weak, ..." (Pinker 1989: 83).

The observation that ASP1 and ASP3 are both associated with a caused possession rather than a caused motion meaning demonstrates the inadequacy of proposals assuming only one meaning, a caused motion meaning involving a Source, a Goal and a Theme, for both constructions. The assumption that the two constructions are associated with only one meaning underlies much of the work dealing with the dative alternation from a generative perspective (cf. Baker 1988; Larson 1988 among others). Given that ASP1 and ASP3 are both associated with a caused possession rather than a caused motion meaning when they occur with verbs of giving, I shall continue to refer to the participants in the relevant actions as an Agent, a Theme and a Recipient. 
Romanian has both an inflectional and a prepositional dative, i.e. a PP consisting of the preposition la and an accusative NP. In standard Romanian, la is followed by some numerals like doi ('two'), plural non-determined adjectives, by nouns, pronouns, measure nouns like parte, often freely alternating with the inflectional dative (cf. ELR 2001: 157; GALR II 2008: 429):

(30a) Oferă autografe cititorilor./ Oferă autografe la cititori offer.3SG autographs readers.DAT.DEF/ offer.3SG autographs to readers în pauză.

in break

'He is offering the readers autographs.' 'He is offering autographs to his readers during the break.'

(30b) Se adresează unei părți dintre cititori. /

he.REFL.CL address.3SG one.F.DAT part.DAT of readers /

Se adresează la $\quad$ o parte dintre cititori.

he.REFL.CL address.3sG to a.F part of readers

'He is addressing a part of his readers.' / 'He is addressing to a part of his readers.' (ELR 2001: 157)

(31) El răspunde studenților. I El răspunde la studenți.

he answer.3SG students.DAT.DEF/ he answer.3SG to students

'He is answering to the students.'

The dative-structure with la may be doubled by a clitic:

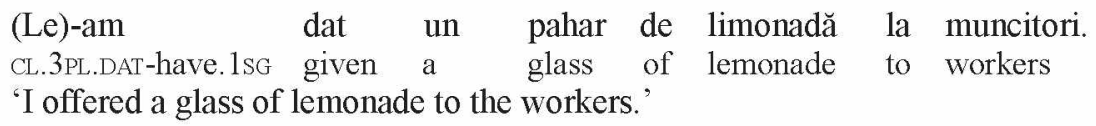

The prepositional dative with $l a$ is frequent in colloquial or regional varieties of Romanian. Prepositional datives with către ('to/towards') also occur in these varieties though not with equal frequency. While la may occur with clitic doubling phenomena (cf. (32)), this is not possible with the prepositional dative with către:

(33) A zis mama către tata într-o zi că eu ştiu hori. have.3sG said mother.DEF to father.DEF in-one day that I know.1sG sing 'Mother told father one day that I knew how to sing ballads.'

(http://www.sibiul.ro/download-pdf/stiri-locale-sibiu/victor-rebengiuc-si-grigore-lese--contemplativi-cu-doru-n-suflet_44996.pdf)

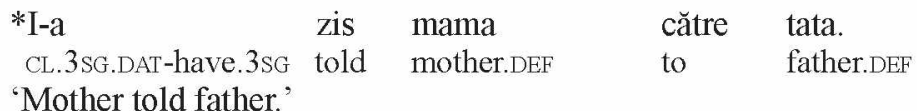

On the whole, ASP3 exists both in German and in Romanian, but in standard Romanian, its occurrence is restricted to certain syntactic and/or lexical environments as described above. However, ASP3 is frequent in colloquial Romanian as well as regional varieties of Romanian.

The fourth pattern, ASP4, is identical in meaning with the patterns mentioned so far but differs formally from these. Specifically, it realises the role of the Recipient as an NP in the 
accusative rather than the dative case and the role of the Theme as a PP headed by mit ('with'): ASP4: JEMANDEN/ETWAS MIT ETWAS VERSORGEN ('supply somebody/something with something')

F: $X_{\text {NP-nom }} V Y_{\text {NP-acc }} Z_{\text {PP mit }}$

$\mathrm{M}$ : $X$ causes $Y$ to receive $Z$ by performing action $V$

Insofar as ASP4 combines the central meaning of the TC with a form different from that of ASP1-ASP3, it has the status of a separate construction. ASP4 is illustrated by (35):

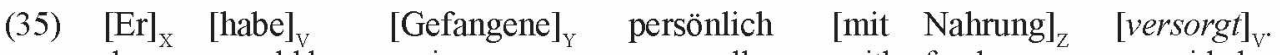
he would have prisoners.ACC personally with food provided 'He would have personally provided prisoners with food.' (Frankfurter Rundschau, 11.4.1998)

Since ASP4 interacts with only four verbs (versorgen ('supply'), ausstatten ('equip'), traktieren ('abuse someone with something / treat someone to something') and beglücken ('bless someone with something')), it is considerably less productive than the patterns mentioned thus far. The fact that these four verbs realise the role of the Recipient as an NP in the accusative rather than the dative case and the role of the transferred entity as a PP headed by mit ('with'), and not as an NP in the accusative case, is an idiosyncratic property of these verbs. ASP4 is therefore unpredictable.

The subject-NP of ASP4 refers to a volitional Agent as in (35). When ASP4 interacts with versorgen, bescheren or beglücken, the first object-NP refers to a willing Recipient. The Recipient co-occurring with traktieren is often not a willing Recipient as in (36):

(36) [Sieben- und achtjährige Lausbuben $]_{\mathrm{X}}$ machten es ihren Vätern nach seven-and eight-year-old raseals made it their.PL.DAT fathers.DAT after und [traktierten $]_{\mathrm{V}}\left[{ }_{\text {SSoldaten }}\right]_{\mathrm{Y}}$ [mit Fußtritten und Faustschlägen $]_{\mathrm{Z}}$. and abused soldiers.ACC with kicks.DAT and punches.DAT 'Seven- and eight-year-old rascals imitated their fathers and abused soldiers with kicks and punches.' (Salzburger Nachrichten, 3.8.1995)

When ASP4 interacts with versorgen, traktieren or beglücken, the referent of the first object-NP is an animate entity. When ASP4 co-occurs with ausstatten, the referent of the first object-NP is an animate or inanimate entity.

The Romanian counterpart of ASP4 interacts with a aproviziona ('supply'), a dărui ('give as a present'), a inzestra ('endow'), a cadorisi ('give as a present'), a ferici ('bless/make someone happy with something'):

(37) $[\text { Autoritățile }]_{\mathrm{X}}[\mathrm{i}-]_{\mathrm{Y}}[\mathrm{au}]_{\mathrm{V}} \quad[\text { aprovizionat }]_{\mathrm{V}}[\mathrm{pe} \text { refugiați }]_{\mathrm{Y}}[\mathrm{cu}$ mâncare authorities.DEF CL.3PL.ACC-have.3PL supplied PE refugees with food şi pături $]_{Z}$. and blankets

'The authorities supplied the refugees with food and blankets.'

Versorgen, bescheren and beglücken may also be used in non-agentive TCs. Since these constructions differ in meaning from ASP4, they constitute a separate argument structure 
pattern:

ASP5: ETWAS VERSORGT JEMANDEN/ETWAS MT ETWAS ('something provides someone/something with something')

F: $X_{\text {NP-nom }} V Y_{\text {NP-acc }} Z_{\text {PPmit }}$

$\mathrm{M}: \mathrm{X}$ is the cause of $\mathrm{Y}$ receiving $\mathrm{Z}$; $\mathrm{V}$ specifies the way in which $\mathrm{Y}$ receives $\mathrm{Z}$

ASP5 is illustrated by (38):

(38) Idealerweise sollten die Brote mit magerer Wurst, Schinken oder Käse belegt sein.

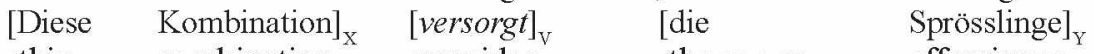
this combination provides the.PL.ACC offspring.PL [mit hochwertigem Eiweiß $]_{Z}, \ldots$ with high quality.DAT protein

'Ideally, the open sandwiches should be topped with lean sausage, ham or cheese. This combination supplies the offspring with high quality protein.' (Neue Kronen-Zeitung, 9.9.1995)

Traktieren does not co-occur with ASP5. ${ }^{9}$

ASP5 appears to lack a Romanian counterpart. The relevant verbs (a unge ('to coat something with something'), a prevedea ('supply/endow'), a imbogăti ('enrich something with something')) all require the subject-NP to have the feature [+agentive] when they co-occur with a pattern which realises the entity transferred as a PP headed by $c u$ ('with'). These verbs permit a non-agentive subject only in combination with double object syntax as in (39):

(39) $\quad[\mathrm{O} \text { astfel de experiență }]_{\mathrm{X}} \quad[\text { iți }]_{\mathrm{Y}} \quad[\text { îmbogăteşte }]_{\mathrm{V}} \quad[\text { viața }]_{\mathrm{Z}}$ : $\begin{array}{lll}\text { a such of experience } & \text { CL.2SG.DAT enrich.3SG life.DEF }\end{array}$ 'Such an experience renders your life richer.'

ASP1-ASP5 relate to the transfer of a Theme from an Agent to a Recipient. The patterns discussed in the next section all refer to a different direction of transfer.

\subsubsection{ASPs relating to transfer away from a Source}

The second group of TCs consists of ASPs relating to the transfer of a Theme $(Z)$ performed by an Agent (X) away from a Source (W). The first ASP of this group, ASP6 (JEMANDEM ETWAS NEHMEN 'take away something from someone'), pairs the form $\left[\mathrm{X}_{\mathrm{NP}-\mathrm{nom}} \mathrm{V}\right.$ $\mathrm{W}_{\mathrm{NP}-\mathrm{dat}} \mathrm{Z}_{\mathrm{NP}-\mathrm{acc}}$ ] with the meaning ' $\mathrm{X}$ causes $\mathrm{X}$ to receive $\mathrm{Z}$ from $\mathrm{W}$ by performing action $\mathrm{V}$ ':

ASP6: JEMANDEM/ETWAS ETWAS NEHMEN (lit.: 'take someone/something something'; 'take away something from someone/something')

9 In addition to ASP1-ASP5, DOCs interacting with throw-verbs prefixed by hin-, zu- or entgegen- (all: 'at') (hinwerfen ('throw at'), zuwerfen ('throw at'), entgegenschleudern ('fling at'), ...) express transfer of a Theme from an Agent to a Recipient. However, since prefixed throw-verbs regularly interact with this pattern, the relevant form-meaning pairing is not an ASP in the sense outlined in section 4. 
F: $\mathrm{X}_{\text {NP-nom }} V W_{\text {NP-dat }} Z_{\text {NP-ace }}$

$\mathrm{M}$ : $\mathrm{X}$ causes $\mathrm{X}$ to receive $\mathrm{Z}$ from $\mathrm{W}$ by performing action $\mathrm{V}$

ASP6 is exemplified by (40):

(40) „Die Spieler akzeptieren sich als Fußballer untereinander nicht“, glaubt Gaßner.

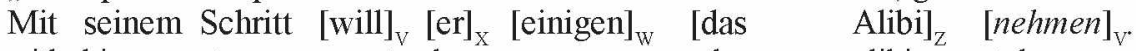
with his step wants he some.DAT the.ACC.N alibi take 'The players do not accept themselves as soccer players among each other, Gaßler believes. With his step, he wants to drop the alibi of some of them.' (Die Rheinpfalz, 2.10.2009)

ASP6 principally interacts with take-verbs, i.e. verbs which either have the meaning 'take' or whose meaning implies 'take'. Examples include abnehmen ('take something from someone'), abpressen ('force something from someone'), enteignen ('dispossess someone'), entziehen ('withdraw something from someone'), nehmen ('take'), entnehmen ('take something out of something'), wegnehmen ('take away'), abspenstig machen ('take/entice/lure something/someone away from someone'), stehlen ('steal'), rauben ('rob'), klauen ('pinch something from someone'), abknöpfen ('manage to get something off/out of someone'), ausspannen ('steal someone's girlfriend/boyfriend'), entwenden ('purloin something from someone'), entlehnen ('borrow'), entleihen ('borrow'), ...

Though ASP6 combines with a relatively large group of take-verbs, it does not interact with a significant number of other verbs of this group, including sich aneignen ('take something'), an sich reißen ('seize something'), sich bemächtigen ('take hold of someone/something'), berauben ('rob someone/something'), beschlagnahmen ('seize something'), einbehalten ('withhold'), einkassieren ('confiscate'), sich einverleiben ('annex'), konfiszieren ('confiscate'), packen ('seize'), etc. Insofar as these verbs belong to the class of take-verbs, the fact that they do not combine with ASP6, while many other take-verbs do, is not predictable either from the rules of grammar or from lexical regularities. Since the co-occurrence of ASP6 with take-verbs largely depends on idiosyncratic properties of the relevant verbs, ASP6 is unpredictable.

The referent of the subject-NP in ASP6 refers to a volitional Agent; the first object-NP of ASP6 refers to an animate being as in (39) or to an inanimate entity as in (41):

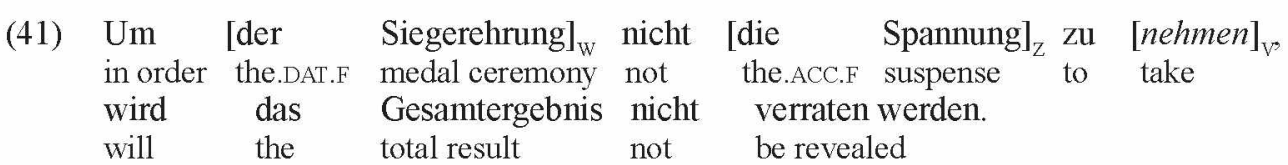
'So as not to diminish the suspense of the medal ceremony, the total result will not be revealed.' (Rhein-Zeitung, 17.4.2003)

The Romanian counterpart of ASP6 co-occurs with the same type of verbs: a lua ('take away'), a fura ('steal'), a şterpeli ('pilfer'), a retrage ('withdraw'), a răpi ('bereave'), etc. ASP6 is exemplified for Romanian by (42): 

(42) $\quad\left[\begin{array}{llllll}\text { Autoritătile }]_{\mathrm{X}} & {[\mathrm{i}-]_{\mathrm{W}}[\mathrm{au}]_{\mathrm{V}}} & {[\text { retras }]_{\mathrm{V}}} & {[\text { Mariei }]_{\mathrm{W}}} & {[\text { dreptul de }} & \text { a }\end{array}\right.$ Authorities.DEF CL.3SG.DAT-have.3PL withdrawn Mary.DAT right.DEF of A profesa ca medic $]_{z}$ profess as doctor 'The authorities have withdrawn Mary her medical authorization.'

In addition to ASP6, the conduit metaphor additionally licenses expressions where the double object pattern combines with fragen ('ask something'), abfragen and abhören (both 'test someone'). Since these verbs realise the role of the Source-argument as an NP in the accusative rather than the dative case, their interaction with the double object pattern constitutes an argument structure pattern (ASP7) which is formally different from ASP6. ASP7 also differs from ASP2 in that (i) the Agent (Speaker) is at the same time the Recipient of the information asked for, and (ii) it involves a Source argument (the hearer as the entity from which the speaker intends to obtain the information asked for):

ASP7: JEMANDEN ETWAS ABFRAGEN (lit.: 'to test someone something'; 'to test someone on something')

$$
\text { F: } \mathrm{X}_{\mathrm{NP}-\text { nom }} \mathrm{V} \mathrm{W}_{\mathrm{NP}-\text {-сcс }} \mathrm{Z}_{\mathrm{NP}-\text {-acc }}
$$

M: $X$ causes $X$ to receive $Z$ from $W$ by performing a verbal action $V$

ASP7 is illustrated by (43):

(43) Dann $[\text { fragt }]_{\mathrm{V}}$ [der Schüler vom äußeren Kreis $]_{\mathrm{X}}$ [sein Gegenüber $]_{\mathrm{W}}$ then asks the pupil of-the outer circle his.ACC opposite [die neuen Vokabeln $]_{\mathrm{Z}} \quad[\mathrm{ab}]_{\mathrm{V}-\mathrm{PART}}$

the.ACC new.PLACC words off

'Then the pupil of the outer circle tests the pupil opposite on the new words of the vocabulary list.' (Berliner Zeitung, 29.10.2002)

ASP7 is highly idiosyncratic in that it combines only with fragen, abfragen and abhören; other speech act verbs do not interact with ASP7.

In Romanian, a asculta ('listen/examine'), a examina ('examine') and a întreba ('ask a question') may also occur with two accusative object-NPs. (44) is a Romanian example of ASP7:

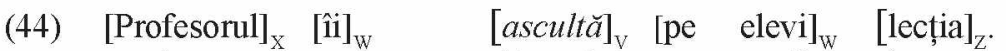
teacher.DEF CL.3PL.ACC listen.3SG PE pupils lesson.DEF

'The teacher is examining the pupils.' (example from Tigău, this volume)

When $X$ is an event, $V$ does not refer to an action but rather specifies the way in which $W$ is caused to lose $Z$. The corresponding pattern has the meaning ' $X$ causes $W$ to lose $Z$ '. Since this meaning is different from that of ASP6 and ASP7, the combination of the form ' $\mathrm{X}_{\mathrm{NP}-\mathrm{nom}} \mathrm{V} \mathrm{W}_{\mathrm{NP}-\mathrm{dat}} \mathrm{Z}_{\mathrm{NP} \text {-acc }}$ ' with the meaning ' $\mathrm{X}$ causes $\mathrm{W}$ to lose $\mathrm{Z}$ ' represents a separate argument structure pattern:

ASP8: ETWAS NIMMT JEMANDEM/ETWAS ETWAS (lit:: 'something takes someone/something something'; 'something takes something away from someone/something') 
$\mathrm{F}: \mathrm{X}_{\text {NP-nom }} V \mathrm{~W}_{\text {NP-dat }} Z_{\text {NP-acc }}$

$\mathrm{M}$ : $\mathrm{X}$ causes $\mathrm{W}$ to lose $\mathrm{Z}$. $\mathrm{X}$ is an event; $\mathrm{Z}$ is a property of $\mathrm{W}$. V specifies

the way in which $W$ is caused to lose $Z$.

ASP8 is exemplified by (45):

(45) Dehling wird Schmerzbehandlung in Form der Zahnextraktion als unaufschiebbar sofort ausführen.

Bei Wurzelbehandlung, $[\mathrm{die}]_{\mathrm{X}}$ ebenfalls $[\text { Schmerzen }]_{\mathrm{Z}}[\text { nimmt }]_{\mathrm{v}}$, sei at root treatment which also pain.PL.ACC takes would be das nicht so klar.

that not so clear

'Pain treatment in the form of tooth extraction, tolerating no delay, will be carried out immediately by Dehling. In the case of root treatment, which also relieves pain, this is not so clear.' (Nürnberger Nachrichten, 20.9.2000)

ASP8 is also attested for Romanian. The Romanian counterpart of ASP8 occurs with similar verbs: a lua ('take away'), a scoate ('take out'), etc.

(46) [Medicamentul ăsta $]_{\mathrm{X}} \mathrm{e}$ aşa de bun că $[i \hat{i ̣ i}]_{\mathrm{W}} \quad[i a]_{\mathrm{V}}$ medicine.DEF this be.3SG so of good that CL.2SG.DAT take away. $3 \mathrm{sG}$ [durerea $]_{7} \mathrm{cu}$ mâna.

pain.DEF with hand.DEF

'This medicine is so good that it takes away the pain in an instant.'

Some of the verbs which co-occur with ASP6 (JEMANDEM/ETWAS ETWAS NEIIMEN) alternatively realise the Source-argument as a PP headed by von ('from') and thereby yield an additional argument structure pattern:

ASP9: ETWAS VON JEMANDEM/ETWAS STEILEN ('steal something from someone/something')

$\mathrm{F}: \mathrm{X}_{\mathrm{NP}-\text {-nom }} \mathrm{VZ} \mathrm{Z}_{\mathrm{NP}-\text { acc }} \mathrm{W}_{\text {PPvon }}$

M: $X$ causes $X$ to receive $Z$ from $\mathrm{W}$ by performing action $\mathrm{V}$

ASP9 is illustrated by (47):

(47) $\quad[\text { Internationale Bande }]_{\mathrm{X}} \quad\left[{ }_{\text {stiehlt }}\right]_{\mathrm{V}}\left[\mathrm{mehr}\right.$ als 60000 Euro $_{\mathrm{Z}} \quad[$ von 57 international gang steals more than 60000 Euro from 57

Bankkunden $]_{\mathrm{W}}$

bank clients.DAT

'International gang steals more than 60000 Euro from 57 bank clients.' (Rhein-Zeitung, 8.6.2007)

ASP9 combines with most but not all verbs interacting with ASP6: abnehmen ('take something from someone'), abpressen ('force something from someone'), nehmen ('take'), wegnehmen ('take away'), stehlen ('steal'), rauben ('rob'), klauen ('pinch something from someone'), abknöpfen ('manage to get something off/out of someone'), entwenden ('purloin something from someone'), entlehnen ('borrow'), entleihen ('borrow'), enteig- 
nen ('dispossess someone'), entziehen ('withdraw something from someone'), abspenstig machen ('take/entice/lure something/someone away from someone') and ausspannen ('steal someone's girlfriend/boyfriend') do not interact with ASP9. Since these verbs are also take-verbs, there is no obvious reason why they should not combine with ASP9. Hence, ASP9 is at least partially idiosyncratic.

The Romanian counterparts of nehmen-verbs (a lua ('take away'), a duce ('take away'), etc.) may also interact with ASP9 as illustrated by (48):

(48) $\begin{aligned} & \text { [Guvernul } \\ & \text { government.DEF }\end{aligned} \quad \begin{aligned} & \text { ăsta }]_{\mathrm{X}} \\ & \text { copiilor }]_{\mathrm{W}}\end{aligned}$
$\begin{aligned} & {[i a]_{\mathrm{V}}} \\ & \text { take away.3SG }\end{aligned}$
children.GEN.DEF
'This government takes away even the bread from the children.'

The Source-argument of ASP9 is an animate entity. If the Source-argument of a nehmenverb is an inanimate entity it may also be realised as a PP headed by aus ('from'). The combination of nehmen-verbs with a PP with aus yields an additional argument structure pattern:

ASP10: ETWAS/JEMANDEN AUS ETWAS NEHMEN ('take something/someone out of something')

$\mathrm{F}: \mathrm{X}_{\mathrm{NP} \text {-nom }} \mathrm{V} \mathrm{Z}_{\mathrm{NP}-\text {-acc }} \mathrm{W}_{\text {PPaus }}$

M: $\mathrm{X}$ causes $\mathrm{X}$ to receive $\mathrm{Z}$ out of $\mathrm{W}$ by performing action $\mathrm{V}$

ASP10 is exemplified by (49):

(49) Nach seinem Bericht $[\text { hatte }]_{\mathrm{V}}[\mathrm{er}]_{\mathrm{X}}$ [das Handy $]_{\mathrm{Z}}$

following his report had he the.ACC.N mobile phone

[aus der Tasche $]_{\mathrm{W}}$ [genommen $]_{\mathrm{V}}, \ldots$

out of the.DAT.F pocket taken

'Following his report, he had taken out his mobile phone from his pocket.' (Nürnberger Nachrichten, 24.6.2005)

ASP10 may in principle combine with any nehmen-verb provided that it allows for a [-animate] Source. Hence, ASP10 may combine with nehmen ('take'), wegnehmen ('take away'), entnehmen ('take something out of something'), klauen ('pinch something from someone'), stehlen ('steal'), rauben ('rob something from someone'), entlehnen ('borrow') and entleihen ('borrow'). Nehmen-verbs which require a [+animate] Source ( $a b$ nehmen ('take something from someone'), abpressen ('force something from someone'), enteignen ('dispossess someone'), abknöpfen ('manage to get something off/out of someone') and ausspannen ('steal someone's boyfriend/girlfriend') do not interact with ASP10. Of all verbs interacting with ASP10, only nehmen and wegnehmen allow the Source-argument to be [+animate] in combination with this pattern. However, in these cases, the expression realising the Source-argument must refer to a group of people (as in jemanden aus einer Gruppe (weg)nehmen) ('to take (away) someone from a group')). 
Romanian take-verbs like a scoate ('take out'), a lua ('take out'), a retine ('retain/take out'), a fura ('steel') also interact with ASP10 as exemplified by (50):

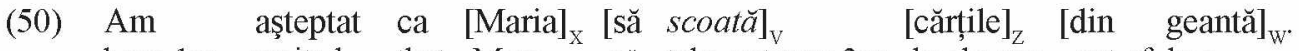
have.1SG waited that Mary SĂ take out.SUBJ.3SG books.DEF out of bag 'I waited for Mary to take out the books from the bag.'

ASP11 (JEMANDEn EINER SACHE BERAUBEN) is synonymous with ASP6 but differs formally from the latter in that it realises the Source-argument as an NP in the accusative rather than the dative case and the Theme-argument as an NP in the genitive rather than the accusative case:

ASP11: JeMANDEN/ETWAS EINER SACHE Berauben (lit.: 'rob someone something'; 'rob someone of something')

$\mathrm{F}: \mathrm{X}_{\mathrm{NP} \text {-nom }}$ beraub $-\mathrm{W}_{\mathrm{NP}-\mathrm{acc}} \mathrm{Z}_{\mathrm{NP}-\text { gen }}$

$\mathrm{M}$ : $X$ causes $X$ to receive $Z$ from $W$ by robbing

ASP11 is illustrated in (51):

(51) Die Menschenschmuggler werden immer brutaler.

Auf der Seestrasse von Otranto [beraubten $]_{\mathrm{V}}\left[\right.$ sie $_{\mathrm{X}}$ in der letzten Woche on the Strait of Otranto robbed they in the last week [eine Gruppe von 26 Flüchtlingen $]_{W}$ [ihrer letzten $\mathrm{Habe}_{Z}$ a.ACC.F group of 26 refugees their.GEN.F last.GEN.F belongings

'Human traffickers are becoming ever more brutal. In the Strait of Otranto, they robbed a group of 26 refugees of their last belongings last week.' (St. Galler Tagblatt, 29.10.1998)

ASP11 only combines with berauben ('rob someone of something'); other take-verbs do not realise their Theme-argument as an NP in the genitive case and hence do not allow this pattern. This means that ASP11 is highly idiosyncratic and only minimally productive. The subject-NP of ASP11 refers to a volitional Agent; the Source-argument is an animate or inanimate entity.

ASP11 does not have an exact counterpart in Romanian: In the corresponding Romanian pattern, the genitive NP must be introduced by a preposition like asupra ('over') or impotriva ('against').

ASP 12 ist formally identical with ASP 11 but differs from the latter pattern in that its subject-NP expresses an event.

ASP12: ETWAS BERAUBT JEMANDEN/ETWAS EINER SACHE (lit:: 'something robs somebody/ something something'; 'something robs someone/something of something')

$\mathrm{F}: \mathrm{X}_{\mathrm{NP} \text {-nom }}$ beraub- $\mathrm{W}_{\mathrm{NP}-\mathrm{acc}} \mathrm{Z}_{\mathrm{NP}-\mathrm{gen}}$

$\mathrm{M}$ : $\mathrm{X}$ causes $\mathrm{W}$ to lose $\mathrm{Z}$ by robbing. $\mathrm{X}$ is an event; $\mathrm{Z}$ is a property of $\mathrm{W}$.

ASP12 is illustrated by (52) and (53): 
(52) „Glaubt denn wirklich jemand, dass alle 27 EU-Staaten einer Vertragsänderung believes truly anyone that all $27 \mathrm{EU}$ states a.DAT.F modification of the zustimmen würden, $[\mathrm{die}]_{\mathrm{X}}[\mathrm{sie}]_{\mathrm{W}}$ [ihres $\quad$ Stimmrechts $]_{\mathrm{Z}}$ contract agree would which they.ACC their.GEN.N right.GEN.N to vote [berauben $]_{\bigvee}[\text { könnte }]_{\bigvee}$ ? ?, sagte Rasmussen ...

rob could said Rasmussen

"Does anyone really believe that all 27 states of the European Union will agree with a modification of the contract which could rob them of their right to vote? ..." said Rasmussen.' (dpa, 28.10.2010)

(53) [Das Minarett der Moschee $]_{\mathrm{W}}\left[\right.$ [wurde $_{\mathrm{V}}$ mit einem gezielten the minaret the.GEN.F mosque was with a.DAT.M precise.DAT.M Schuss [seiner Spitze $]_{Z}[\text { beraubt }]_{V}$. shot its.GEN.F spire robbed

'The minaret of the mosque was deprived of its spire with a precision shot.' (Frankfurter Rundschau, 8.10.1998)

Like ASP11, ASP12 only combines with berauben ('rob someone of something'); other take-verbs do not allow this pattern.

ASP12 does not have a counterpart in Romanian. ${ }^{10}$

\subsubsection{ASPs relating to transfer from a Source to a non-specified location}

The next ASP, ASP13, relates to transfer of an entity (Z) from a Source (W) to a nonspecified location. ASP13 combines the ditransitive pattern, $X_{\mathrm{NP}-\mathrm{nom}} \mathrm{VW}_{\mathrm{NP}-\mathrm{dat}} \mathrm{Z}_{\mathrm{NP}-\mathrm{acc}}$, with the meaning ' $\mathrm{X}$ causes $\mathrm{Z}$ to be separated from $\mathrm{W}$ by performing action $\mathrm{V}$ ':

ASP13: JEMANDEM/ETWAS ETWAS ENTFERNEN (lit.: 'remove someone/something something'; 'remove something from someone/something')

$\mathrm{F}: \mathrm{X}_{\mathrm{NP}-\mathrm{nom}} \mathrm{VW} \mathrm{W}_{\text {NP-dat }} Z_{\mathrm{NP}-\mathrm{acc}}$

$\mathrm{M}$ : $\mathrm{X}$ causes $\mathrm{Z}$ to be separated from $\mathrm{W}$ by perfoming action $\mathrm{V}$

ASP13 is illustrated in (54):

(54) Um wirklich sicher zu gehen, schoss $[\mathrm{er}]_{\mathrm{X}}$ zahlreiche Fotos von dem Tier to really sure to go shot he numerous pictures of the animal

10 In addition to ASP6-ASP12, transitive patterns like etwas beschlagnahmen ('seize something') may also be regarded as argument structure patterns expressing the notion of transfer of an entity (the Theme) performed by an Agent away from a Source. They may be described as pairing the form ' $\mathrm{X}_{\mathrm{NP}-\mathrm{nom}} \mathrm{V} \mathrm{Z}_{\mathrm{NP}-\text { acc }}$ ' with the meaning ' $\mathrm{X}$ causes $\mathrm{X}$ to receive $\mathrm{Z}$ from $\mathrm{W}$ by performing action $\mathrm{V}$.' Since the Source (W) is understood to be present without being syntactically expressed, such form-meaning pairings are formally different from ASP6-ASP12 and would therefore appear to represent a distinct ASP. However, since transitive verbs generally combine with the relevant form-meaning pairing, the interaction of this pattern with transitive take-verbs appears to be rule-governed. The pattern is therefore highly productive. This means that it is not an argument structure pattern in the sense outlined in section 4 . 
und [entfernte $]_{\mathrm{V}}[\mathrm{ihm}]_{\mathrm{W}}$ vorsichtig [zwei Federn $]_{\mathrm{z}}$ für eine Genanalyse. and removed it.DAT carefully two feathers for a genetic analysis 'To make really sure, he shot numerous pictures of the animal and carefully removed two feathers from it for a genetic analysis. ${ }^{11}$ (dpa, 7.3.2007)

ASP13 interacts with verbs like entfernen ('remove'), amputieren ('amputate') and ausreiBen ('pull out', 'tear out'). Since there do not seem to be any verbs of this class which do not combine with ASP13, the interaction of ASP13 with verbs of removal seems to be rulegoverned. This means that it is not an argument structure pattern in the sense outlined in section 4. The pairing of form and meaning in ASP13 is not idiosyncratic either, because verbs like entfernen require an Agent, a Theme and a Source. This means that, in this case, the ditransitive pattern may also be argued to be determined by the independent specifications of the verb. ASP13 is mentioned here, because it alternates with the prepositional patterns ASP14 and ASP15 (see below).

The subject-NP of ASP13 usually refers to a volitional Agent as in (54). The verb entfernen interacts with ASP13 only when its Source-argument is an animate entity as in (54). When its Source-argument is an inanimate entity, entfernen combines with ASP14 or ASP15 (ETWAS VON/AUS ETWAS ENTFERNEN; see below). The Source-argument of amputieren is always an animate entity. Ausreißen combines with ASP13 irrespective of whether its Source-argument is an animate entity as in (55) or an inanimate entity as in (56):

(55) Eine aufgehängte Stoffbahn, $[\operatorname{der}]_{\mathrm{W}} \quad[\text { Kolod }]_{\mathrm{X}}$ [einen rechteckigen

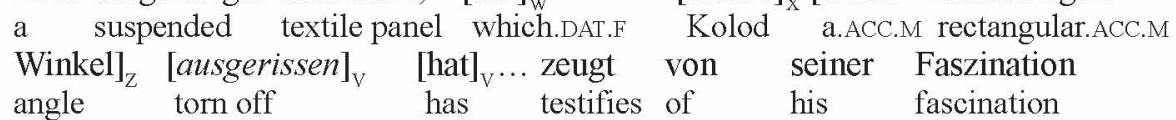

mit dem "ewigen Fall des Stoffes".

with the eternal fall of the material

"A suspended textile panel from which Kolod has torn off a rectangular angle is evidence of his fascination with the eternal fall of the material.' (Frankfurter Rundschau, 9.4.1998)

(56) Andere wurden mit Stricken an den Gliedmaßen aufgehängt, oder $[\mathrm{man}]_{\mathrm{X}}$ others were with ropes at the limbs hung or one $[\text { hat }]_{\mathrm{V}} \quad[\text { ihnen }]_{\mathrm{W}}[\text { die } \quad \text { Fingernägel }]_{\mathrm{Z}}$ [ausgerissen $]_{\mathrm{V}}$. has they.DAT the.PL.ACC fingernails pulled out

'Others were hung up with ropes attached to their limbs or had their fingernails pulled out.' (Nürnberger Zeitung, 21.11.2007)

The Romanian counterpart of ASP13 also interacts with verbs of removal: a lua ("take away'), a amputa ('amputate'), a înlătura ('move away/remove'), a îndepărta ('move away/remove'), a suprima ('cut out'), ... as exemplified by (57):

(57) $\quad[\text { Doctorii }]_{\mathrm{X}}[\mathrm{i}-]_{\mathrm{W}}[\mathrm{au}]_{\mathrm{V}} \quad[\text { amputat }]_{\mathrm{V}}$ [lui $\quad$ Ion $]_{\mathrm{W}} \quad[$ piciorul doctors.DEF CL.3SG.DAT-have.3PL amputated ART.DAT John leg.DEF

11 In examples like (54), ASP13 combines with the Part-of-Whole Construction ('Pertinenzkonstruktion'): the dative NP ihm is the Source-argument of the verb entfernen as well as the Possessor-argument of the NP zwei Federn. 


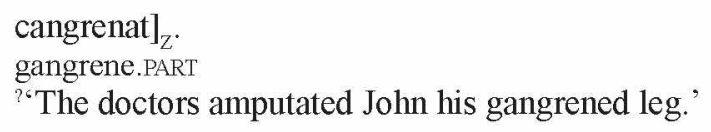

Entfernen and ausreißen may also realise the Source-argument as a PP headed by von ('from'), thereby yielding ASP14, which is instantiated by (58):

ASP14: ETWAS VON ETWAS ENTFERNEN ('remove something from something')

$\mathrm{F}: \mathrm{X}_{\mathrm{NP}-\mathrm{nom}} \mathrm{V} \mathrm{Z}_{\mathrm{NP} \text {-acc }} \mathrm{W}_{\mathrm{PP} \text { von }}$

$\mathrm{M}$ : $\mathrm{X}$ causes $\mathrm{Z}$ to be separated from $\mathrm{W}$ by performing action $\mathrm{V}$

(58) „Jedes Parfum stellen wir selbst her", sagt Edith Lehmann und each perfume manufacture we ourselves says Edith Lehmann and [entfernt $]_{\mathrm{V}}$ [den Glasverschluss $]_{\mathrm{Z}}$ [von einer Flasche $]_{\mathrm{W}}$. removes the.ACC.M glass top from a.DAT.F bottle

"We manufacture each perfume ourselves", Edith Lehmann says and removes the glass top from a bottle.' (Berliner Zeitung, 22.2.2003)

The Source-argument of ASP14 is an inanimate entity as in (58) or a body part (as in die Crème vom Gesicht entfernen ('remove the cream from the face') and die Haare von den Beinen entfernen ('remove the hair from the legs')).

Romanian verbs like a indepărta ('take away') and a scoate ('take out') also co-occur with ASP14 as attested by (59):

(59) După o aşa faptă $\quad[\text { părinții }]_{\mathrm{X}} \quad\left[\operatorname{ssi}_{\mathrm{X}} \quad[1-]_{\mathrm{Z}}[\mathrm{au}]_{\mathrm{V}} \quad[\operatorname{scos}]_{\bigvee} \quad[\right.$ pe after a such deed parents.DEF and CL.3sG.M.ACC-have.3PL taken out PE fiul $\quad$ lor $]_{Z} \quad$ de la inimă $]_{W}$.

son.DEF their from heart

'As a consequence of his deed, his parents gave up loving their son.'

Alternatively, entfernen and ausreißen may realise the Source-argument as a PP headed by aus ('off/out of'). The co-occurrence of these verbs with a PP with aus yields an additional argument structure pattern:

ASP15: ETWAS AUS ETWAS ENTFERNEN ('remove something out of something')

$\mathrm{F}: \mathrm{X}_{\mathrm{NP}-\text { nom }} \mathrm{V} \mathrm{Z} \mathrm{N}_{\mathrm{NP}-\mathrm{acc}} \mathrm{W}_{\mathrm{PP} \text { aus }}$

$M$ : $X$ causes $Z$ to be separated from $W$ and removed out of $W$ by performing action $V$

ASP15 is exemplified by (60):

(60) [Ein Pfarrer $]_{\mathrm{X}}[\text { hat }]_{\mathrm{V}}$ [alle Liebesszenen $]_{\mathrm{Z}}$ [aus den Filmen $]_{\mathrm{W}}$ a parson has all.PL.ACC love scenes from the.PL.DAT films.DAT $\left.[\text { entfernen }]_{\mathrm{V}}[\text { lassen }]_{\mathrm{V}}\right]_{\mathrm{V}}$. remove let

'A parson has let all love scenes be removed from the films.' (Tiroler Tageszeitung, 8.11.1996)

The Source argument of ASP15 is usually an inanimate entity as in (60) or a group of individuals. 
The Romanian verb a smulge ('tear out') also co-occurs with ASP15 as exemplified by $(61)$ :

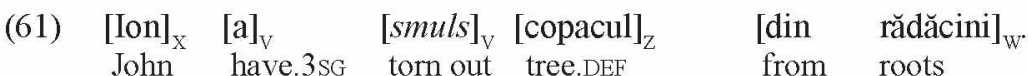

'John has torn out the tree from the earth.'

ASP13-ASP15, which all relate to transfer from a Source to a non-specified location, are attested for German as well as Romanian and interact with verbs of removal in both languages. The ASPs discussed in the next section relate to transfer from a non-specified location to an Agent/Recipient.

\subsubsection{ASPs relating to transfer from a non-specified location to an Agent/Recipient}

ASP16 relates to the transfer of an entity (Z) from a non-specified location to a Recipient (Y). ASP16 differs formally from all other transfer-ASPs in that it expresses the Recipient as an NP in the accusative case and the entity transferred as an NP in the genitive case. ASP16 has the meaning ' $\mathrm{X}$ causes $\mathrm{Y}$ to possess $\mathrm{Z}$ by seizing $\mathrm{Z}$ ', where $\mathrm{X}$ and $\mathrm{Y}$ refer to the same entity:

ASP16: SICH EINER SACHE BEMÄCHTIGEN (lit.: 'oneself of something seize'; 'seize something')

F: $\mathrm{X}_{\mathrm{NP}-\mathrm{nom}}$ bemächtig- $\mathrm{Y}_{\mathrm{NP}-\text { acc }} \mathrm{Z}_{\mathrm{NP}-\text { gen }}$

M: $X$ causes $Y$ to possess $Z$ by seizing $Z ; X=Y$

ASP16 is instantiated by (62):

(62) [Die arabischen Machthaber in der Nachbarschaft $]_{X}$ ihrerseits [versuchten $]_{V}$ the Arab rulers in the neighbourhood in turn attempted

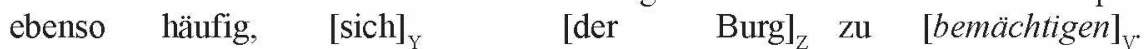
just as frequently themselves.ACC the.GEN.F castle to seize

'The neighbouring Arab rulers in turn attempted just as frequently to seize the castle.' (Krtek76; Bender235; BWBot; u.a.: Krak des Chevaliers, in: Wikipedia :http://de.wikipedia.org: Wikipedia, 2005)

ASP16 is highly idiosyncratic in that it combines with no other verb than bemächtigen ('seize').

The subject-NP of ASP16 usually refers to a volitional Agent as in (62). It may also refer to an inanimate entity as in (63):

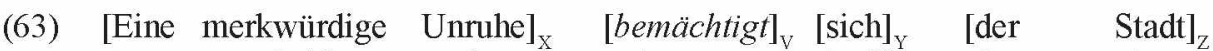
a remarkable restlessness seizes itself.ACC the.GEN.F city

im Juli und August.

in July and August

'A remarkable restlessness takes hold of the city in July and August.' (die tageszeitung, 30.7.1990) 
(63) is licensed by a metaphor extending the meaning of ASP16 into the inchoative meaning 'become A', where $\mathrm{A}$ is an adjective designating a property of the Theme (in (63): 'restless'). The source domain of the metaphor is the notion of transfer, its target domain the notion of an entity coming to have a certain property. An abstract entity is seen as an Agent causing itself (Y) to possess another entity (Z).

Since the first object-NP (sich) is coreferent with the subject-NP, the former refers either to an animate being as in (62) or an inanimate entity as in (63), depending on the referent of the subject-NP.

ASP16 does not have a counterpart in Romanian.

\subsubsection{ASPs relating to transfer from a non-specified location/Source to a Goal}

ASP17 combines the ditransitive pattern, ' $\mathrm{X}_{\mathrm{NP}-\text {-nom }} \mathrm{V} \mathrm{U}_{\mathrm{NP}-\mathrm{dat}} \mathrm{Z}_{\mathrm{NP}-\mathrm{acc}}$ ', with the meaning ' $\mathrm{X}$ causes $Z$ to become part of $U$ by performing action $V$ ' ( $U$ is the Goal which $Z$ is transferred to):

ASP17: ETWAS ETWAS HINZUFÜGEN (lit:: 'add something something'; 'add something to something')

$$
\text { F: } X_{\text {NP-nom }} V U_{\text {NP-dat }} Z_{\text {NP-acc }}
$$

M: $X$ causes $Z$ to be part of $U$ by performing action $V$

ASP17 is illustrated by examples like (64):

(64) In einer Erklärung des französischen Außenministeriums heißt es:

"[Herr Schröder $]_{\mathrm{X}}[\text { hat }]_{\mathrm{V}}[$ der Debatte über die europäische

Mr Schröder has the.DAT.F debate on the.ACC.F European.ACC.F

Zukunft $]_{\mathrm{U}}$ [einen neuen Beitrag $]_{\mathrm{Z}}$ [hinzugefügt $]_{\mathrm{V}}$ "“

future a.ACC.M new.ACC.M contribution added

"In a statement of the French Foreign Ministry it is stated that "Mr Schröder has added a new contribution to the debate about the future of Europe."' (Frankfurter Allgemeine, 2.5.2001)

ASP17 combines with verbs like hinzufügen ('add'), anheften ('attach something to something'), aufkleben ('stick something on something'), beisteuern ('contribute'), implantieren ('implant'), einbauen ('build something into something/fit something into something'), einfiigen ('insert'), eingliedern ('incorporate something into something'), etc. However, ASP17 does not interact with ergänzen ('complete'). Since ergänzen is similar in meaning to all other verbs of this group, the fact that it does not allow ASP17 indicates that ASP17 is at least partially unpredictable.

The subject-NP of ASP17 may alternatively refer to a volitional Agent as in (64) or an inanimate entity which is the cause of the entity referred to by the second object-NP becoming part of the entity referred to by the first object-NP. In (65), for example, X (eine Farce ('a farce')) causes Z (neues Unrecht ('new injustice') to be part of U (altes Unrecht ('old injustice')): 
(65) "Wenn das nicht möglich ist“, sagt er, „,dann sollten wir ganz auf einen Prozess erzichten - das ist besser als eine Farce vor einem lokalen Gericht,

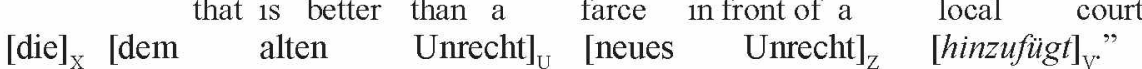
which the.DAT.M old.DAT.M injustice new.ACC.N injustice adds "If that is not possible", he said, "then we should waive legal proceedings entirely that is better than a farce in front of a local court, which would add new injustice to old injustice."' (die tageszeitung, 10.02.2000)

(65) is licensed by a metaphorical extension of the meaning of ASP17: an abstract entity is seen as an Agent causing an entity (the Theme) to be part of another entity (the Goal).

With the exception of implantieren ('implant'), the first object-NP of ASP17 refers to an inanimate entity. Hence, it is usually a Goal rather than a Recipient.

ASP17 interacts with the same verbs in Romanian as in German: a adăuga ('add'), a implanta ('implant'), a pune ('put'):

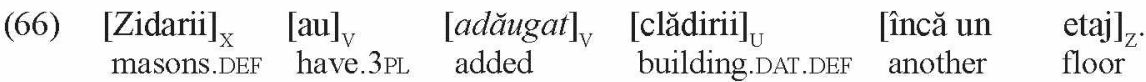
'The masons added another floor to the building.'

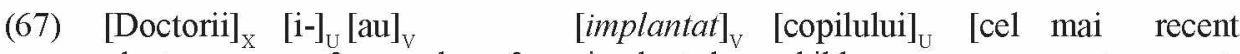
doctors.DEF CL.3SG.DAT-have.3PL implanted child.DAT.DEF ART most recent implant cohlear $]_{Z}$. implant cochlear 'The doctors implanted the most recent cochlear implant into the child.'

Verbs like hinzufiugen may alternatively realise the Goal-argument as a PP headed by an (lit.: 'at') (ASP18) or $z u$ ('to') (ASP19):

ASP18: ETWAS AN ETWAS HINZUFÜGEN (lit.: 'add something at something'; 'add something to something')

F: $\mathrm{X}_{\mathrm{NP}-\mathrm{nom}} \mathrm{V} \mathrm{Z}_{\mathrm{NP}-\mathrm{acc}} \mathrm{U}_{\mathrm{PPam}}$

$\mathrm{M}$ : $\mathrm{X}$ causes $\mathrm{Z}$ to be part of $\mathrm{U}$ by performing action $\mathrm{V}$

ASP18 is exemplified by (68):

(68) Die überlasteten Behörden könnten uns Bürgern ja solche Feinheiten selbst überlassen. Aber in Wirklichkeit reagieren sie äußerst allergisch, wenn $[\mathrm{man}]_{\mathrm{X}}$ but in reality react they extremely allergically if one [an einem Ausweis $]_{U}$ auch nur [ein i-Tüpfelchen $]_{Z}[\text { hinzufügt }]_{V}$. at a.DAT.M identity card even only a.ACC.N i-dot adds

'The overburdened government authorities could leave such subtleties to us citizens after all. But in reality they display a severe allergic reaction if one so much as adds a single i-dot to one's identity card.' (Nürnberger Nachrichten, 8.7.1998)

ASP18 is not attested for Romanian. 
ASP19: ETWAS ZU ETWAS HINZUFÜGEN ('add something to something')

F: $\mathrm{X}_{\mathrm{NP}-\mathrm{nom}} \mathrm{VZ} \mathrm{Z}_{\mathrm{NP}-\mathrm{acc}} \mathrm{U}_{\mathrm{PP} z u}$

$\mathrm{M}$ : $\mathrm{X}$ causes $\mathrm{Z}$ to be part of $\mathrm{U}$ by performing action $\mathrm{V}$

ASP19 is exemplified by (69):

(69) [Stanley Prusiner $]_{\mathrm{X}}[\text { hat }]_{\mathrm{V}}$ [die Prionen $]_{\mathrm{Z}}[\mathrm{zu}$ der $\quad$ Liste der Stanley Prusiner has the.PL.ACC prions to the.DAT.F list the.PL.GEN gut bekannten Erreger von Infektionen wie Bakterien, well known.GEN.PL causative agents of infections.DAT such as bacteria Viren, Pilze und Parasiten $]_{U}$ [hinzugefügt $]_{V}$. viruses funguses and parasites added

'Stanley Prusiner has added prions to the list of well-known causative agents of infections such as bacteria, viruses, fungi and parasites.' (Kleine Zeitung, 7.10.1997)

ASP19 is exemplified for Romanian by (70):

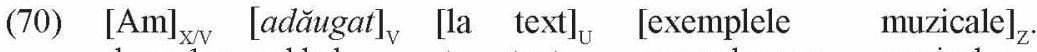
have.1SG added to text examples.DEF musical.PL 'I added the music examples to the text.'

Einfügen ('insert'), eingliedern ('incorporate something into something'), implantieren ('implant') and einbauen ('build something into something') do not interact with ASP18 and ASP19. As opposed to the other verbs of the hinzufingen-class, they may realise the Goal-argument as a PP headed by in. ${ }^{12}$

ASP20: ETWAS IN ETWAS EINFÜGEN ('insert something into something')

F: $\mathrm{X}_{\mathrm{NP}-\text { nom }} \mathrm{VZ} Z_{\mathrm{NP}-\mathrm{acc}} \mathrm{U}_{\mathrm{PP} \text { in }}$

$\mathrm{M}$ : $\mathrm{X}$ causes $\mathrm{Z}$ to be inner part of $\mathrm{U}$ by performing action $\mathrm{V}$

ASP20 is illustrated by (71):

(71) $[\text { Hugo Freund }]_{X}\left[\text { soll }_{Y} \text { Textabschnitte verschieben und [eine Grafik }\right]_{Z}$ Hugo Freund should text passages move and a.ACC.F graphic [in einen Text $]_{U}$ [einfügen $]_{V^{*}}$ in a.ACC.M text insert 'Hugo Freund should move text passages and insert a graphic in a text.' (die tageszeitung, 19.8.2003)

ASP20 has an exact counterpart in Romanian interacting with the same verbs: $a$ inser $a$ ('insert'), a introduce ('insert'), a băga ('insert') and a incorpora ('incorporate'). The interaction of ASP20 with these verbs is illustrated by (72):

(72) Ca articolul să fie complet [trebuie $]_{\mathrm{X} / \mathrm{V}}\left[\mathrm{să}_{\mathrm{V}}\right.$ mai $[\text { inserezi }]_{\mathrm{V}}$ in order to article.DEF SĂ be.SUBJ. $3 \mathrm{SG}$ complete must.2SG SĂ more insert.2SG [ceva informații $]_{Z} \quad\left[\begin{array}{ll}11 & \text { el }\end{array}\right]_{U}$. some information.DEF in it

'You must insert some more information into the article so that it might be complete.'

12 The co-occurrence of einbauen with the corresponding DOC pattern (ASP17) is attested but unusual. 
ASP1-ASP20 all relate to transfer of an entity in a particular direction: transfer from an Agent to a Recipient (ASP1-ASP5), transfer away from a Source (ASP6-ASP12), transfer from a Source to a non-specified location (ASP13-15), transfer from a non-specified location/Source to a Recipient (ASP16), or transfer from a non-specified location to a Goal (ASP17-ASP20) ${ }^{13}$. ASP1-ASP20 therefore constitute a subfamily of the family of transfer constructions. The remaining constructions relate to other aspects of transfer.

\subsubsection{ASPs relating to intended future transfer}

ASP21 JEMANDEM ETWAS BESORGEN/GET SOMEONE SOMETHING, relates to an intention of future transfer. It pairs the form ' $\mathrm{X}_{\mathrm{NP}-\mathrm{nom}} \mathrm{V} \mathrm{Y}_{\mathrm{NP}-\mathrm{dat}} \mathrm{Z}_{\mathrm{NP} \text {-acc }}$ ' with the meaning ' $\mathrm{X}$ intends to cause $Y$ to receive $Z$ at some future point in time':

ASP21: JEMANDEM/ETWAS ETWAS BESORGEN ('get someone/something something')

$\mathrm{F}: \mathrm{X}_{\mathrm{NP}-\text { nom }} \mathrm{V} \mathrm{Y}_{\mathrm{NP}-\mathrm{dat}} \mathrm{Z}_{\mathrm{NP}-\mathrm{acc}}$

M: $X$ intends to cause $Y$ to receive $Z$ at some future point in time by performing action $\mathrm{V}$

ASP21 is illustrated in (73):

(73) In der Nacht im Hotel in Genua [besorgt $]_{\mathrm{V}}\left[\right.$ sie $_{\mathrm{X}}[\mathrm{ihm}]_{\mathrm{Y}}$ in the night in-the hotel in Genoa gets she he.DAT persönlich noch [zwei Crèmes brulées $]_{\mathrm{Z}}, \ldots$

personally additionally two crèmes brulées

'At night in the hotel in Genoa, she personally also got him two crèmes brulées, ...' (die tageszeitung, 28.7.2001)

ASP21 interacts with verbs of the following classes:

- Verbs of obtaining: besorgen ('get/obtain'), beschaffen ('supply'), herausschlagen ('make something out of someone/something'), verschaffen ('get/obtain/procure'), kaufen ('buy'), holen ('fetch'), mieten ('rent/lease'), bestellen ('order'), ....

- Not all verbs of obtaining co-occur with ASP21. Verbs which do not allow the construction include: ergattern ('get hold of something'), erhaschen ('grab'), erlangen ('obtain'), erringen ('win'), erwerben ('acquire'), ...

- Verbs of creation: anfertigen ('make'), bauen ('build'), basteln ('do handicrafts'), dichten ('write/compose'), drechseln ('turn'), errichten ('erect'), erschaffen ('create'), fabrizieren ('manufacture'), fertigen ('manufacture'), herstellen ('produce'), konstruieren ('design'), malen ('paint'), machen ('make'), meißeln ('chisel'), nähen ('sew'), schmieden ('forge'), schnitzen ('carve'), weben ('weave'), spinnen ('spin'), stricken ('knit'), ...

13 In addition to ASP17-ASP20, prepositional patterns interacting with throw-verbs (werfen ('throw'), schmeißen ('throw'), schleudern ('fling')) also express transfer from a non-specified location to a Goal. However, since these verbs regularly co-occur with a pattern consisting of a direct object-NP followed by a PP with auf ('on') or gegen ('against'), the relevant form-meaning pairing is not an ASP in the sense outlined in section 4. 
- However, erzeugen ('generate'), produzieren ('produce') and hervorbringen ('produce'), which are used to refer to acts of creation in general, do not allow ASP21. The combination of these verbs with a ditransitive pattern yields instances of the benefactive construction rather than the TC as in Ich werde mir mein Mineralwasser ganz einfach selbst produzieren (Rhein-Zeitung, 2.8.1997) ('I will simply make myself my own mineral water').

- vererben, vermachen, hinterlassen (all 'leave/bequeath'), übertragen ('to make over something to someone'), and ïberschreiben ('to sign over something to someone')

- verkaufen ('sell') and vermieten ('let/rent out')

- Commissives: versprechen ('promise'), anbieten ('offer'), garantieren ('guarantee'), androhen ('threaten'), versichern ('assure'), zusichern ('assure'), zusagen ('promise'), geloben ('vow'), schwören ('swear'), offerieren ('offer'), antragen ('offer'), gewährleisten ('guarantee')

- All other commissives, a much larger group including verbs like drohen ('threaten'), einwilligen ('agree'), sich verpflichten ('commit oneself'), verzichten ('renounce'), and vereinbaren ('agree'), do not allow ASP21. (See Winkler (2007a) on the argument structure patterns of German commissives.)

- Send-verbs: schicken ('send'), senden ('send'), liefern ('deliver'), bringen ('bring'), zustellen ('deliver') (except prefixed verbs like abschicken ('send off'), absenden ('send off') and versenden ('send off'))

The co-occurrence of verbs of obtaining, verbs of creation, commissive speech act verbs, bequeath-verbs and send-verbs with the TC is also attested for English (see Table 1; especially Goldberg 1995: 32). In addition to these classes, suchen ('search'), fischen ('fish'), angeln ('angle') and jagen ('hunt') also interact with ASP21, cf. (74):

(74) Einmal $\quad\left[\begin{array}{lllll}\text { sucht }]_{\mathrm{V}} & {[\text { sie }]_{\mathrm{X}}} & {[\mathrm{ihm}]_{\mathrm{Y}}} & \text { übers Internet [eine }\end{array}\right.$ on one occasion searches she he.DAT over-the internet a.ACC.F sympathische Freundin $]_{Z}, \ldots$ nice.ACC.F girlfriend

'On one occasion she searches a nice girlfriend for him over the internet, ...' (Nürnberger Nachrichten, 28.5.2009)

However, ASP21 is not used with other search-verbs (fahnden ('search'), spähen ('peer'), spionieren ('spy'), forschen ('research'), etc. ${ }^{14}$ ).

Since ASP21 combines with all send-verbs and with almost all verbs of creation, it is most productive with verbs of these classes. It is somewhat less productive with verbs of obtaining and considerably less so with commissives, most of which do not combine with ASP21. The latter is also true of search-verbs, only four of which interact with this pattern. The co-occurrence of ASP21 with verbs of obtaining, verbs of creation and searchverbs expands the argument structure of these verbs. These verbs are all two-place predi-

14 A similar study on the German Search-Construction has shown that search-verbs do not allow the Search-Construction without exception either (cf. Proost 2009). 
cates which gain a Recipient-argument when co-occurring with ASP21. When ASP21 interacts with verbs of these classes, the Recipient is also at the same time a Beneficiary.

In Romanian, ASP21 interacts with the same verbs: $a-i$ lua ('get something for someone'), a face rost ('get'), a asigura ('ensure'), a obtine ('obtain'), a procura ('get'), a cumpăra ('buy') as attested by the examples in (75) and (76):

(75) În ciuda greutăților, [părinţii $]_{\mathrm{X}}$ au reuşit $[\text { să- }]_{\mathrm{V}}[\mathrm{i}]_{\mathrm{Y}}$ in spite difficulties.DAT.DEF parents.DEF have.3PL managed SĂ-CL.3SG.DAT

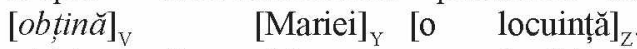
obtain.SUBJ.3PL Mary.DAT a dwelling

'In spite of the difficulties they encountered, her parents managed to obtain a dwelling for Mary.'

(76) În felul ăsta $[\mathrm{i}-]_{\mathrm{Y}}[\mathrm{au}]_{\mathrm{XV}} \quad[\text { asigurat }]_{\mathrm{Y}}[\text { fetei } \quad \text { lor }]_{\mathrm{Y}}[\text { viitorul }]_{\mathrm{Z}}$. in way.DEF this CL.3SG.DAT-have.3PL ensured daughter.DAT.DEF their future.DEF 'In this way, they have cared for their daughter's future.'

Verbs like vererben ('bequeath') may alternatively realise the Recipient-argument as a PP headed by auf ('on'):

ASP22: ETWAS AUF JEMANDEN VERERBEN (lit.: 'bequeath something on someone'; 'bequeath something to someone')

$\mathrm{F}: \mathrm{X}_{\mathrm{NP}-\text { nom }} \mathrm{V} \mathrm{Z}_{\mathrm{NP}-\mathrm{acc}} \mathrm{Y}_{\text {PPauf }}$

$\mathrm{M}$ : $\mathrm{X}$ intends to cause $\mathrm{Y}$ to receive $\mathrm{Z}$ at some future point in time by performing action $\mathrm{V}$

ASP22 is instantiated by (77):

(77) [Thre Freude am Kreuzworträtseln $]_{Z}$ [hat $]_{V} \quad\left[\right.$ sie $_{X}$ her.ACC pleasure at-the doing crossword-puzzles has she [auf ihren Sohn Boris $]_{Z}[\text { vererbt }]_{V}$. on her.ACC.M son Boris bequeathed

'Her pleasure at doing crossword-puzzles she has passed on to her son Boris.' (RheinZeitung, 19.3.2004)

ASP22 co-occurs with vererben ('bequeath'), übermachen ('make over something to someone') and überschreiben ('sign over something to someone'), but not with their synonyms vermachen and hinterlassen (both: 'bequeath/leave').

ASP22 is not attested for Romanian. Romanian verbs which allow a prepositional variant in addition to ASP21 require the PP to be headed by la (English: lit. 'at'; German: 'an'). The Romanian pattern with la corresponds to ASP23, not to ASP22.

ASP23, ETWAS AN IEMANDEN SCHICKEN ('send something to someone'), is synonymous with ASP21 but differs formally from this pattern in that it expresses the Recipient as a PP headed by an (lit.: 'at'; 'to'). The Recipient also follows rather than precedes the Theme: 
ASP23: ETWAS AN JEMANDEN/ETWAS SCHICKEN 'send something to someone/something'

F: $\mathrm{X}_{\mathrm{NP}-\text { nom }} \mathrm{V} \mathrm{Z} \mathrm{Z}_{\mathrm{NP}-\mathrm{acc}} \mathrm{Y}_{\mathrm{PPan}}$

$\mathrm{M}$ : $\mathrm{X}$ intends to cause $\mathrm{Y}$ to receive $\mathrm{Z}$ at some future point in time by performing action $\mathrm{V}$

ASP23 is illustrated in (78):

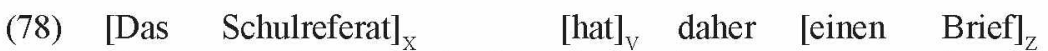
the department of schools has hence a.Acc.m letter [an den Städtetag $]_{Y} \quad[\text { geschickt }]_{V}, \ldots$

to the.ACC.M association of cities sent

'The department of schools hence has sent a letter to the German congress of municipalities, ...' (Nürnberger Nachrichten, 3.6.1995)

ASP23 interacts with schicken ('send'), senden ('send') and liefern ('deliver') but not with other send-verbs such as bringen ('bring') and zustellen ('deliver'). Since ASP23 does not generally combine with send-verbs, it is partially unpredictable. ASP23 also interacts with verkaufen ('sell') and vermieten ('let/rent out') and with bequeath-verbs (vererben, vermachen, übermachen, überschreiben) but not with hinterlassen.

The subject-NP of ASP23 refers to a volitional Agent and the first object-NP to a willing Recipient as in (78).

In spite of what has been claimed in the literature about the semantics of DOCs and their prepositional variants (see discussion of ASP1 vs. ASP3), neither ASP21 nor ASP23 necessarily implies that transfer has been successful. Expressions built on either type of construction may be continued by a clause cancelling the implication of successful transfer as shown in (79) and (80):

(79a) Ich habe meinem Onkel ein Paket geschickt, aber er hat es I have my.DAT.M uncle a.ACC.N package sent but he has it.ACC nie bekommen.

never received

'I have sent my uncle a package, but he has never received it.'

(79b) Ich habe ein Paket an meinen Onkel geschickt, aber er hat I have a.ACC.N package to my.ACC.M uncle sent but he has es nie bekommen.

it.ACC never received 'I have sent a package to my uncle, but he has never received it.'

(80a) Ich habe meiner Schwester zwei Karten fürs Theater besorgt, I have my.DAT.F sister two tickets for-the.ACC.N theatre got aber ich habe sie ihr noch nicht gegeben. but I have they.ACC she.DAT yet not given 'I have got my sister two tickets for the theatre, but I have not yet given them to her.'

(80b) Ich habe zwei Karten fürs Theater für meine Schwester I have two tickets for-the.ACC.N theatre for my.ACC.F sister besorgt, aber ich habe sie ihr noch nicht gegeben. got but I have they.ACC she.DAT yet not given "I have got two tickets for the theatre for my sister, but I have not yet given them to her.' 
Obviously, this is due to the fact that the notion of actual and successful transfer is not part of the meaning of verbs like send, promise and bequeath, these verbs expressing future rather than actual transfer. Since these verbs require the first object-NP of the DOC / the NP-complement of the preposition in the prepositional variant to refer to an animate entity, I shall refer to the role realised by these expressions as the intended Recipient. The role of a Goal will be reserved for inanimate entities as in ASP17-ASP20 (the ASPs interacting with add-verbs).

The Romanian counterpart of ASP23 interacts with the same verbs in German and Romanian: a trimite ('send'), a transmite ('send'), a livra ('deliver'), a lăsa ('leave'), a aduce ('bring'), ... ASP23 is exemplified for Romanian by (81):

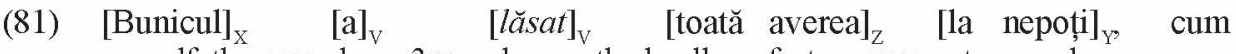
grandfather.DEF have.3SG bequeathed all fortune.DEF at grandsons as era de așteptat.

be.IMPF. 3SG DE expect.SUP

'Grandfather has bequeathed his entire fortune to his grandsons, as expected.'

ASP24: ETWAS FÜR JEMANDEN/ETWAS BESORGEN ("obtain something for someone/ something')

F: $\mathrm{X}_{\mathrm{NP} \text {-nom }} \mathrm{VZ}_{\mathrm{NP} \text {-acc }} \mathrm{Y}_{\text {PPfir }}$

$\mathrm{M}$ : $\mathrm{X}$ intends to cause $\mathrm{Y}$ to receive $\mathrm{Z}$ at some future point in time by performing action $\mathrm{V}$; Y benefits from X's performing $\mathrm{V}$

ASP24 is illustrated by (82):

(82) Also [besorgte $]_{\mathrm{V}}[\text { Lule Zeqiri }]_{\mathrm{X}}$ alle paar Tage [Lebensmittel $]_{\mathrm{Z}}[$ für die so obtained Lule Zeqiri every few days food for the.Acc.F Familie $]_{Y}{ }^{15}$.

family

'So Lule Zeqiri obtained food for the family every few days.' (Berliner Zeitung, 24.4.1999)

ASP24 regularly co-occurs with verbs of obtaining and verbs of creation and with the search-verbs which also co-occur with ASP21 (suchen ('search'), fischen ('fish'), angeln ('angle') and jagen ('hunt')).

The Romanian counterpart of ASP24 expresses the Recipient/Beneficiary as a PP headed by pentru ('for'), as exemplified by ( 83 ):

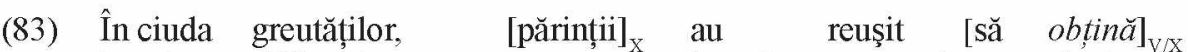
in spite difficulties.DAT.DEF parents.DEF have.3PL managed SA obtain.SUBI.3PL [o locuință $]_{Z}$ [pentru Maria $]_{Y}$ a dwelling for Mary

'In spite of the difficulties they encountered, her parents managed to obtain a dwelling for Mary.'

15 The for-phrase of ASP24 can also be interpreted as an attribute to the preceding accusative NP. This ambiguity occurs systematically with ASP24. 
In Romanian, ASP24 interacts with the same verbs which co-occur with ASP21 (a lua ('get'), a face rost ('get'), a asigura ('ensure'), a obține ('obtain'), ...).

\subsubsection{ASPs relating to the permission or prohibition of transfer}

ASP25, JEMANDEM ETWAS ERLAUBEN ('permit someone something'), pairs the ditransitive pattern ' $\mathrm{X}_{\mathrm{NP}-\mathrm{nom}} \mathrm{V} \mathrm{Y}_{\mathrm{NP}-\mathrm{dat}} \mathrm{Z}_{\mathrm{NP} \text {-acc }}$ ' with the meaning ' $\mathrm{X}$ enables $\mathrm{Y}$ to receive $\mathrm{Z}$ ':

ASP25: JEMANDEM ETWAS FRLAUBEN ('permit someone something')

F: $X_{\text {NP-nom }} V Y_{\text {NP-dat }} Z_{\text {NP-acc }}$

$\mathrm{M}$ : $\mathrm{X}$ enables $\mathrm{Y}$ to receive $\mathrm{Z}$

ASP25 is exemplified by (84):

(84) Einmal in der Woche $\left[\text { erlauben }_{\mathrm{V}}[\mathrm{ihm}]_{\mathrm{Y}} \text { [die Pfleger }\right]_{\mathrm{X}}$ [eine Zigarre $_{\mathrm{Z}}$. once in the week allow he.DAT the nurses a.ACC.F cigar 'Once a week, the nurses allow him a cigar.' (Rhein-Zeitung, 19.8.1996)

ASP25 combines with verbs of permission such as erlauben ('allow/permit'), gestatten ('allow/permit'), gewähren ('grant'), genehmigen ('grant permission'), bewilligen ('approve something for someone'), freistellen ('leave something up to someone'), and zugestehen ('grant'). However, it does not combine with einwilligen ('consent'), zustimmen ('agree'), and billigen ('approve of something'). (See Winkler (2007b) on the argument structure patterns of permission verbs and other directives). Since ASP23 co-occurs with some verbs of permission but not with others, it is partially unpredictable.

The referent of the subject-NP of ASP25 is a speaker, the referent of the first object-NP a hearer.

Since the verbs interacting with ASP25 are all (directive) speech act verbs, ASP25 may be considered a metaphorical instance of the TC. However, the meaning of ASP25 ('X enables $Y$ to receive $Z$ ') cannot be considered a metaphorical extension of the meaning of ASP1 (' $X$ causes $Y$ to receive $Z$ '), because the former expresses the concept of permission of transfer, while the latter expresses the concept of causation of transfer. Since none of the other ASPs mentioned so far is related to the permission of transfer either, all ASPs mentioned lack a feature which may correspond to the target feature of permission of transfer. ASP25 therefore constitutes a pattern of its own.

The Romanian counterpart of ASP25 also co-occurs with verbs like allow and permit: a permite ('allow'), a da voie ('allow'), a aproba ('approve') as illustrated by (85):

(85) $\left[\begin{array}{llllll}\text { Primăria }]_{\mathrm{X}} & \text { nu } & {[\mathrm{i}-]_{\mathrm{Y}}[\mathrm{a}]_{\mathrm{V}}} & {[\text { aprobat }]_{\mathrm{V}}} & {[\text { Mariei }]_{\mathrm{Y}}} & {[\text { cererea }]_{\mathrm{Z}} \text {. }}\end{array}\right.$ townhall.DEF not CL.3SG.DAT-have.3SG approved Mary.DAT request.DEF 'The townhall did not approve Mary's request.'

ASP26, JEMANDEM ETWAS VERWEIGERN ('refuse someone something'), has the same form as ASP25 but pairs this form with the meaning ' $\mathrm{X}$ causes $\mathrm{Y}$ not to receive $Z$ ': 
ASP26: JEMANDEM ETWAS VERWEIGERN ('refuse someone something')

F: $X_{\text {NP-nom }} V Y_{\text {NP-dat }} Z_{\text {NP-acc }}$

M: $X$ causes $Y$ not to receive $Z$

ASP26 is instantiated by examples such as (86):

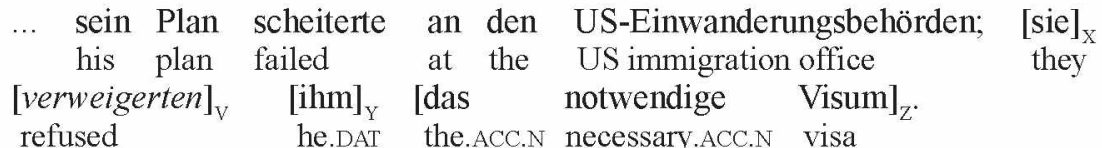
refused he.DAT the.ACC.N necessary.ACC.N visa

'... his plan failed because of the US immigration office; they refused him the necessary visa.' (Nürnberger Nachrichten, 22.9.2001)

ASP26 interacts with verbs of refusal including verweigern ('refuse'), abschlagen ('deny'), verbieten ('forbid'), untersagen ('forbid/prohibit'), and verwehren ('refuse') but does not combine with other verbs of refusal such as sich verbitten ('not to tolerate something from someone'), unterbinden ('stop'), and sich verwahren ('protest'). (See Winkler (2007b) on the argument structure patterns of forbid-verbs and other directives). Since ASP26 does not generally combine with verbs of refusal, it is partially unpredictable.

The referent of the subject-NP of ASP26 is a speaker, the referent of the first object-NP a hearer.

ASP26 may not be considered a metaphorical extension of the meaning of ASP1 or the meaning of any of the other patterns, because none of the patterns mentioned contains an element which the target feature of prohibition of transfer may correspond to. For this reason, ASP26 must be treated as a separate pattern.

ASP26 has an exact counterpart in Romanian which co-occurs with the same verbs: $a$ refuza ('refuse') and a interzice ('forbid') as exemplified by (87):

(87) $\left[\begin{array}{lllll}\text { Primăria }]_{\mathrm{X}} & {[\mathrm{i}-]_{\mathrm{Y}}[\mathrm{a}]_{\mathrm{V}}} & {[\text { refuzat }]_{\mathrm{V}}} & {[\text { Mariei }]_{\mathrm{Y}}} & {[\text { cererea }]_{Z} \text {. }}\end{array}\right.$ townhall.DFF CL.3SG.DAT-have.3Sg refused Mary.DAT request.DEF

'The townhall refused Mary's request.'

\subsection{Results of the comparison of TCs in German and Romanian}

\subsubsection{Distribution}

The TC has 26 variants in German. Some of these appear to lack an equivalent in Romanian. APSs which lack a Romanian counterpart are:

- ASP5: ETWAS VERSORGT JEMANDEN/ETWAS MIT ETWAS ('something provides someone with something')

- ASP11: JeMANDEN/ETwas einer SACHe Berauben (lit.: 'rob someone something'; 'rob someone of something')

- ASP12: etwas BeRAUbT JEMANDEN/ETwas EINER Sache (lit.: 'something robs someone/ something something', 'something robs someone/something of something') 
- ASP16: sich einer Sache bemächtigen (lit.: 'oneself of something seize'; 'seize something')

- ASP18: eTWAS AN ETWAS HINZUFÜGEN (lit:: 'add something at something'; 'add something to something')

- ASP22: ETWAS AUF JEMANDEN VERERBEN (lit.: 'bequeath something on someone'; 'bequeath something to someone')

Conversely, the comparison of TCs in German and Romanian has revealed only one pattern which exists in Romanian but not in German: the verb a arunca ('throw') combines with an NP in the accusative case and a PP headed by prepositions such as asupra ('over') and impotriva ('against') which take a genitive NP-complement:

(88) E uşor să arunci acuzaţii asupra persoanelor pe are nu be.3SG easy SĂ throw.2SG accusations.DEF over persons.GEN.DEF PE who not le cunoști.

CL.3PL.ACC know.2SG

'It is easy to accuse people you do not know.'

As we have seen, throw-verbs do not interact with the TC in German unless they are prefixed by hin-, zu- or entgegen- (as in hinschmeißen, zuschmeißen (both 'throw something at someone') or entgegenschleudern ('throw something to someone')). Obviously, the fact that the comparison of TCs has revealed a larger number of ASPs for German than for Romanian is a consequence of the procedure taking German as the basis of comparison. A considerably larger number of Romanian patterns may have turned out to exist if Romanian patterns had been gathered first and their German counterparts had been searched for afterwards. The most interesting result of the comparison of TCs in German and Romanian is the lack of Romanian counterparts of ASP18 (ETWAS AN ETWAS HINZUFÜGEN (lit.: 'add something at something'; 'add something to something')) and ASP22 (ETWAS AUF JEMANDEN VERERBEN (lit.: 'bequeath something on someone'; 'bequeath something to someone')). In German, these patterns exist alongside ASP19 (ETWAS ZU ETWAS HINZUFÜGEN ('add something to something')) and ASP22 (ETWAS AN JEMANDEN/ETWAS VERERBEN (lit.: 'bequeath something at something')) respectively, which contain different prepositions. This means that the ditransitive patterns comprising the same verbs, ASP17 (ETWAS ETWAS HINZUFUGGEN (lit.: 'add something something')) and ASP21 (JEMANDEM ETWAS VERERBEN ('bequeath someone something')) have only one prepositional variant in Romanian as opposed to two in German. As a consequence of the lack of these patterns, some classes of Romanian verbs do not permit the dative alternation while their German equivalents do.

\subsubsection{Alternations}

ASPs which alternate in German and/or Romanian are listed in Table 3: 


\begin{tabular}{|c|c|c|c|c|}
\hline Alternating patterns & Formal description & Verbs & German & Romanian \\
\hline $\begin{array}{l}\text { ASP1: jmdm. (etwas) etwas } \\
\text { übergeben / } \\
\text { ASP3: etwas an jmdn. } \\
\text { übergeben }\end{array}$ & \begin{tabular}{|l}
$\mathrm{X}_{\mathrm{NP}-\text { nom }} \mathrm{V} \mathrm{Y}_{\mathrm{NP}-\text { dat }} Z_{\mathrm{NP}-\mathrm{acc}}$ \\
$\mathrm{X}_{\mathrm{NP}-\mathrm{nom}} \mathrm{VZ}_{\mathrm{NP} \text {-acc }} \mathrm{Y}_{\mathrm{PP} \text { an }}$
\end{tabular} & give-Vs & $\begin{array}{c}\mathrm{X} \\
\text { with a large number of } \\
\text { exceptions } \\
\text { (see discussion of } \\
\text { ASP3) }\end{array}$ & $\begin{array}{c}\mathrm{X} \\
\text { ASP3 for some } \\
\text { verbs restricted } \\
\text { to colloquial } \\
\text { speech or } \\
\text { regional } \\
\text { varieties }\end{array}$ \\
\hline $\begin{array}{l}\text { ASP6: jmdm. etwas stehlen/ } \\
\text { ASP9: etwas von jmdm. } \\
\text { stehlen }\end{array}$ & 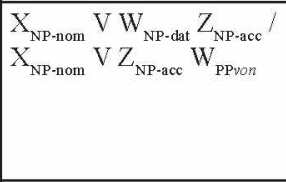 & take-Vs & $\begin{array}{c}\mathrm{X} \\
\text { with the exception of } \\
\text { enteignen, entziehen, } \\
\text { abspenstig machen and } \\
\text { ausspannen }\end{array}$ & $\mathrm{X}$ \\
\hline $\begin{array}{l}\text { ASP6: etwas etwas } \\
\text { entnehmen / } \\
\text { ASP10: etwas aus etwas } \\
\text { entnehmen }\end{array}$ & \begin{tabular}{|l|}
$\mathrm{X}_{\text {NP-nom }} \mathrm{VW}_{\mathrm{NP}-\text { dat }} Z_{\mathrm{NP}-\text { acc }}$ \\
$\mathrm{X}_{\text {NP-nom }} \mathrm{VZZ}_{\mathrm{NP} \text {-acc }} \mathrm{W}_{\mathrm{PP} \text { aws }}$
\end{tabular} & take-Vs & $\begin{array}{l}\text { only entnehmen } \\
\text { (only if there is no } \\
\text { body-body part } \\
\text { relationship between } \\
\text { W and Z) }\end{array}$ & $\mathrm{X}$ \\
\hline $\begin{array}{l}\text { ASP13: etwas etwas } \\
\text { ausreißen } \\
\text { ASP15: etwas aus etwas } \\
\text { ausreißen }\end{array}$ & \begin{tabular}{|l}
$\mathrm{X}_{\mathrm{NP} \text {-nom }} \mathrm{V} \mathrm{W} \mathrm{W}_{\mathrm{NP}-\text { dat }} \mathrm{Z}_{\mathrm{NP}-\mathrm{acc}}$ \\
$\mathrm{X}_{\mathrm{NP} \text {-nom }} \mathrm{VZZ}_{\mathrm{NP} \text {-acc }} \mathrm{W}_{\mathrm{PP} \text { acis }}$
\end{tabular} & remove-Vs & $\begin{array}{l}\text { entfernen, ausreißen } \\
\text { (only if there is no } \\
\text { body-body part } \\
\text { relationship between } \\
\text { W and Z) }\end{array}$ & --- \\
\hline $\begin{array}{l}\text { ASP17: etwas etwas } \\
\text { hinzufügen / } \\
\text { ASP18: etwas an etwas } \\
\text { hinzufügen }\end{array}$ & 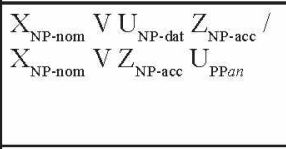 & $\mathrm{add}-\mathrm{Vs}$ & \begin{tabular}{|c|} 
except einfügen, \\
eingliedern, einbauen, \\
implantieren
\end{tabular} & $\mathrm{X}$ \\
\hline $\begin{array}{l}\text { ASP17: etwas etwas } \\
\text { hinzufügen } \\
\text { ASP19: etwas zu etwas } \\
\text { hinzufügen }\end{array}$ & \begin{tabular}{|l}
$\mathrm{X}_{\mathrm{NP}-\mathrm{nom}} \mathrm{VU}_{\mathrm{NP}-\mathrm{dat}} \mathrm{Z}_{\mathrm{NP}-\mathrm{acc}}$ \\
$\mathrm{X}_{\mathrm{NP}-\mathrm{nom}} \mathrm{V} \mathrm{Z}_{\mathrm{NP}-\mathrm{acc}} \mathrm{U}_{\mathrm{PP} Z u}$
\end{tabular} & $a d d-V_{s}$ & $\begin{array}{c}\text { except einfügen, } \\
\text { eingliedern, einbauen, } \\
\text { implantieren }\end{array}$ & --- \\
\hline $\begin{array}{l}\text { ASP17: etwas etwas } \\
\text { einfügen } \\
\text { ASP20: etwas in etwas } \\
\text { einfügen }\end{array}$ & \begin{tabular}{|l}
$\mathrm{X}_{\mathrm{NP}-\text { nom }} \mathrm{VU}_{\mathrm{NP}-\text { dat }} \mathrm{Z}_{\mathrm{NP} \text {-acc }}{ }^{\prime}$ \\
$\mathrm{X}_{\mathrm{NP} \text {-nom }} \mathrm{V} Z_{\mathrm{NP} \text {-acc }} \mathrm{U}_{\mathrm{PP} i n}$
\end{tabular} & $a d d-V s$ & $\begin{array}{c}\text { only } \\
\text { eingliedern, einfügen, } \\
\text { implantieren, } \\
{\text { (einbauen })^{16}} \\
\end{array}$ & $\mathrm{X}$ \\
\hline $\begin{array}{l}\text { ASP21: jmdm. etwas } \\
\text { vererben } \\
\text { AS22: etwas auf jmdn. } \\
\text { vererben }\end{array}$ & $\begin{array}{l}\mathrm{X}_{\text {NP-nom }} \mathrm{V} \mathrm{Y}_{\text {NP-dat }} Z_{\text {NP-acc }} \\
\mathrm{X}_{\text {NP-nom }} \mathrm{VZ}_{\text {NP-acc }} \mathrm{Y}_{\mathrm{PP} \text { cauf }}\end{array}$ & bequeath-Vs & $\begin{array}{c}\text { only } \\
\text { vererben, } \\
\text { uberschreiben, } \\
\text { übermachen }\end{array}$ & 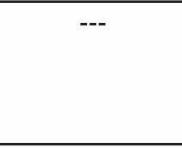 \\
\hline $\begin{array}{l}\text { ASP21: jmdm. etwas } \\
\text { schicken / } \\
\text { ASP23: etwas an jmdn. } \\
\text { schicken }\end{array}$ & \begin{tabular}{|l}
$\mathrm{X}_{\text {NP-nom }} \mathrm{VY}_{\text {NP-dat }} Z_{\text {NP-acc }}$ \\
$\mathrm{X}_{\text {NP-nom }} \mathrm{VZ}_{\text {NP-acc }} \mathrm{Y}_{\mathrm{PP} a n}$
\end{tabular} & send-Vs & $\begin{array}{c}\text { only } \\
\text { schicken, senden, } \\
\text { liefern }\end{array}$ & $\mathrm{X}$ \\
\hline $\begin{array}{l}\text { ASP21: jmdm. etwas } \\
\text { besorgen / } \\
\text { ASP24: etwas für jemanden } \\
\text { besorgen }\end{array}$ & \begin{tabular}{|l}
$\mathrm{X}_{\text {NP-nom }} \mathrm{V} \mathrm{Y}_{\text {NP-dat }} Z_{\text {NP-acc }} /$ \\
$\mathrm{X}_{\text {NP-nom }} \mathrm{V} \mathrm{Z}_{\text {NP-acc }} \mathrm{Y}_{\text {PPflur }}$
\end{tabular} & $\begin{array}{l}\text { obtain-Vs/ } \\
\text { Vs of } \\
\text { creation, } \\
\text { some } \\
\text { search-Vs }\end{array}$ & $\mathrm{X}$ & $\mathrm{X}$ \\
\hline
\end{tabular}

Table 3: Alternations of DOCs and prepositional variants in German and Romanian ${ }^{16}$

16 The co-occurrence of ASP17 with einbanen is attested but unusual. 
The findings on alternating patterns summarized in Table 3 show that:

(i) Both Romanian and German allow the double object pattern to interact with takeverbs, remove-verbs and add-verbs, which do not allow the DOC in English. Since these double object patterns have at least one prepositional variant in both languages, Romanian and German show a larger number of potentially alternating patterns than English. Obviously, the presence of a DOC as well as a prepositional pattern interacting with the same verbs is only a prerequisite for an alternation. Whether potentially alternating patterns actually do alternate additionally depends on other factors as shown in (ii) and (iii) for German.

(ii) In German, DOC patterns which have a prepositional variant with which they could alternate in principle often do not do so, because one variant is restricted to co-occurring with an expression referring to an animate entity while the other only cooccurs with an expression referring to an inanimate entity. This is true, for example, of ASP13 vs. ASP14 and ASP13 vs. ASP15 when these patterns interact with the verb entfernen ('remove'). When the Source-argument of entfernen is a body, and its Theme-argument is a part of that body, entfernen requires the DOC-variant and blocks the PP-variant (cf. den Möusen Hautstücke entfernen (lit.: 'remove the mice pieces of the skin') vs. "'Hautstücke von/aus den Möusen entfernen (lit.: 'remove pieces of skin from/out of the mice')). When there is no such body-body part relation between the Source- and the Theme-argument of entfernen and the Source is an inanimate entity, only the prepositional pattern is allowed (cf. den Glasverschluss von der Flasche entfernen ('remove the glass top from the bottle') vs. ?" der Flasche den Glasverschluss entfernen ('remove the bottle the glass top'); Liebesszenen aus dem Film entfernen ('remove love scenes from the film') vs. ${ }^{.92}$ dem Film Liebesszenen entfernen ('remove the film love scenes')). When there is no body-body part relationship between the Source- and the Theme-argument and the Source-argument is an animate entity, sometimes only the DOC pattern is allowed (cf. dem Dieb die Fesseln entfernen (lit.: 'remove the thief the chains') vs. "? die Fesseln vom Dieb entfernen ('remove the chains from the thief')), while the patterns may alternate in other cases (cf. die Decke vom Patienten entfernen ('remove the blanket from the patient') vs. dem Patienten die Decke entfernen (lit.: 'remove the patient the blanket')). Due to the presence or absence of a body-body part relationship between the Source- and Theme-argument of entfernen and the inanimacy of the Source, ASP13 and ASP14 are to a large extent mutually exclusive when they co-occur with entfernen. The same is true of ASP13 and ASP15.

(iii) The alternation between ASP13 and ASP15 is possible, irrespective of whether the Source is an animate or inanimate entity, only when these patterns interact with ausreißen ('tear out') and there is no body-body part relationship between the Source and the Theme (cf. der Stoffbahn einen Winkel ausreißen ('tear out the textile panel an angle') vs. einen Winkel aus der Stoffbahn ausreißen ('tear an angle out of the textile panel'); dem Verletzten das Messer ausreißen (lit.:"tear out the injured 
person the knife') vs. das Messer aus dem Verletzten ausreißen ('tear out the knife from the injured person')). However, if the Source-argument of ausreißen is a body and its Theme is a part of that body, DOC is required and the prepositional pattern is blocked (cf. dem Kind ein Haar ausreißen (lit.: 'tear out the child a hair') vs. "? ein Haar aus dem Kind ausreißen (lit.: 'tear a hair out of the child' )).

Likewise, the alternation between ASP6 and ASP10 is possible only when these patterns interact with entnehmen ('take something out of something'), and there is no body-body part relationship between the Source- and Theme-argument (cf. der Schublade ein Dokument entnehmen (lit.: 'take the drawer a document') / ein Dokument ous der Schublade entnehmen ('take a document out of the drawer')). If the Source-argument of entnehmen is a body and its Theme a body part, DOC is required and the prepositional pattern is blocked (cf. dem Patienten Blut entnehmen lit.: 'take the patient a blood sample' vs. ?" Blut aus dem Patienten entnehmen ('take a blood sample out of the patient')).

These two examples also show that the first object-NP of a DOC is not generally reserved for expressions referring to [ + animate] entities as has been argued with respect to DOCs in English (cf. Green 1974: 103-105; Goldberg 1995: 143-146), which, as opposed to DOCs in German, do not interact with take- or remove-verbs. As soon as Source-arguments are taken into account in addition to Recipients, the constraints proposed for DOCs in general no longer hold. The observations made with respect to the dative alternations involving take- and remove-verbs also show that the dative alternation is not motivated by pragmatic factors alone as has been argued with respect to the English dative alternation (cf. Erteschik-Shir 1979; Timyam/Bergen 2010). The precise conditions under which individual verbs or verb classes allow the dative alternation in German or Romanian are a matter of further research.

(iv) The alternating patterns differ considerably with respect to their degree of productivity. Verbs which participate in the dative alternation have been shown to belong to a limited number of semantic classes, but these classes differ considerably with respect to the number of verbs which actually permit the dative alternation. There are many more verbs of giving and taking which participate in the dative alternation than verbs of removal, add-verbs, bequeath-verbs or send-verbs which permit this alternation. In this respect, the dative alternation may be regarded to be more productive with the former than with the latter. Even though many give- or take-verbs which allow the DOC pattern (ASP1 and ASP6 respectively) do not allow the prepositional pattern (ASP3 and ASP9 respectively), a considerable number of them do allow the dative alternation. Rappaport Hovav/Levin (2008: 162) have argued that German does not show a dative alternation with what they call "core dative verbs such as give". However, all verbs which allow ASP1 (the DOC pattern co-occurring with give-verbs) and/or ASP3 (the prepositional variant interacting with give-verbs) inherently take three arguments: an Agent, a Theme and a Recipient. Additionally, 
it is not the case that all or even most German verbs which do not show the dative alternation are non-prefixed verbs while those which do allow the alternation are prefixed. Thus, German verbs which do not show the dative alternation are neither semantically nor morphologically more "basic" than those which do allow the alternation. Hence, there seems to be no point in calling them "core" dative verbs. Conversely, it makes no sense to regard those which do allow the alternation as being "non-core" or "peripheral" dative verbs. The dative alternation is clearly less productive with German add-verbs and even less so with German insert-, bequeath- and send-verbs, only few of which alternate between the DOC and the prepositional pattern. The dative alternation is least productive with remove-verbs. Due to the body-body part relationship between the Source- and Theme-argument of ausreißen ('tear out'), this verb is the only remove-verb showing the dative alternation.

(v) The following patterns alternate in Romanian: ASP1 ('give someone (something) something')/ASP3 ('hand over something to someone'), ASP6 (lit.: 'steal someone something')/ASP9 ('steal something from someone'), ASP6 (lit.: 'take something something')/ASP10 ('take something out of something'), ASP17 (lit.: 'add something something'/ASP18 (lit.: 'add something at something'), ASP17 (lit.: 'insert something something'/ASP20 ('insert something into something'), and ASP21 ('get someone something'/ASP24 ('get something for someone'). Due to the lack of some prepositional patterns in Romanian, Romanian does not permit the following alternations: ASP13 (lit.: 'tear out something something')/ASP15 ('tear something out of something'), ASP17/(lit.: 'add something something')/ASP18 ('add something to something'), and ASP21 ('bequeath someone something')/ASP22 (lit.: 'bequeath something at someone').

\subsubsection{Constraints on the subject-NP and first object-NP in German as opposed to English ditransitives}

\subsubsection{Volitionality of the Agent}

Most of the ASPs discussed are agentive, the only exceptions being ASP5 (ETWAS VERSORGT JEMANDEN/ETWAS MIT ETWAS), ASP8 (ETWAS NIMMT JEMANDEM/ETWAS ETWAS) and ASP12 (etwas Beratbi JEMANDEN/ETWAS EINER SACHE). All agentive ASPs involve an Agent which either can or must have control over the action described by the verb.

The following ASPs involve an Agent which must have control over the action described by the verb as may be seen from the fact that the examples of each of them cannot be combined with the adverb versehentlich ('accidentally') (see discussion of volitionality in section 2). (In the examples below, "\#" is used to indicate that the sentence is well-formed only if it is interpreted as containing an expression used by a speaker who describes the action performed by the Agent. For example, He has accidentally given her a book is well-formed if the referent of the subject-NP intended to give the Recipient a CD but happened to give 
$\mathrm{him} / \mathrm{her}$ a book. In that case, the action of giving someone something was intended although the object transferred was not the one intended by the speaker. This means that accidentally does not cancel the Agent's intention in these cases. "?" is used to indicate that the sentence may hardly be interpreted at all.)

(i) ASP1: JEMANDEM/ETWAS ETWAS GEBEN

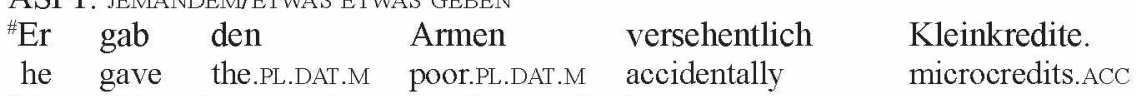

'He accidentally gave the poor microcredits.'

(ii) ASP2: JEMANDEN ETWAS LEHREN
'Er hat die Amerikaner versehentlich demokratische

he has the.PL.ACC Americans accidentally democratic.PL.ACC

Grundwerte gelehrt.

basic values taught

'He has taught the Americans basal democratic values.'

(iii) ASP3: ETWAS AN JEMANDEN ÜBERGEBEN

'Rabani übergab versehentlich die Präsidentschaft an Karsai.

Rabani handed over accidentally the.ACC.F presidency to Karsai

'Rabani accidentally handed over the presidency to Karsai.'

(iv) ASP4: JEMANDEN/ETWAS MIT ETWAS VERSORGEN

"Er versorgte die Gefangenen versehentlich mit Nahrung.

he provided the.PL.ACC prisoners accidentally with food

'He accidentally provided the prisoners with food.'

(v) ASP6: JEMANDEM/ETWAS ETWAS NEHMEN

${ }^{\#}$ Er hat den Spielern versehentlich das Alibi genommen.

he has the.PL.DAT. players.DAT. accidentally the.ACC.N alibi taken

'He has accidentally deprived the players of their alibi.'

(vi) ASP7: JEMANDEN ETWAS ABFRAGEN

'Der eine Schüler fragte den anderen versehentlich die

the one pupil asked the.ACC.M other.ACC.M accidentally the.PL.ACC

Vokabeln $a b$.

new words off

'One pupil accidentally tested the other one on the vocabulary list.'

(vii) ASP9: ETWAS VON JEMANDEM/ETWAS STEHLEN

"Die Bande stiehlt versehentlich Geld von Bankkunden.

the gang steals accidentally money from bank clients.DAT

'The gang accidentally steals money from bank clients.'

(viii) ASP11: JEMANDEN/ETWAS EINER SACHE BERAUBen

'Der Schmuggler beraubte die Flüchtlinge versehentlich

the smuggler robbed the.PL.ACC refugees accidentally

ihrer letzten Habe.

their.GEN.F last.GEN.F belonging

'The smuggler accidentally robbed the refugees of their last belongings.' 
(ix) ASP16: sich einer SACHe BemÄChtTGen

${ }^{2}$ Der Fürst hat sich versehentlich der Burg bemächtigt. the prince has himself.ACC accidentally the.GEN.F castle seized 'The prince has accidentally seized the castle.'

(x) ASP21: JEMANDEM/ETWAS ETWAS BESORGEN

${ }^{\text {\#}}$ Sie besorgte ihm versehentlich zwei Crèmes brulées.

she got he.DAT accidentally two crèmes brulées

'She accidentally got him two crèmes brulées.'

(xi) ASP22: ETWAS ALF JEMANDEN VERERBEN

'Jede Generation vererbt den Ring versehentlich auf die nächste.

each generation bequeaths the.ACC.M ring accidentally to the.ACC.F next.ACC.F

'Each generation accidentally bequeaths the ring to the next one.'

(xii) ASP23: ETWAS AN JEMANDEN SCHICKEN

"Er hat versehentlich einen Brief an den Städtetag

he has accidentally a.ACC.M letter to the.ACC.M congress of municipalities geschickt.

sent

'He has accidentally sent a letter to the congress of municipalities.'

(xiii) ASP24: ETWAS FÜR JEMANDEN/ETWAS BESORGEN

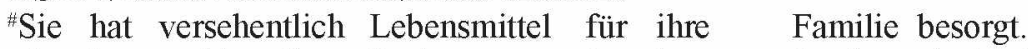

she has accidentally food for her.Acc.F family obtained

'She has accidentally obtained food for her family.'

(xiv) ASP25: JEMANDEM ETWAS ERLAUBEN

${ }^{4}$ Die Pfleger erlauben ihm versehentlich eine Zigarre.

the nurses allow he.DAT accidentally a.ACC.F cigar

'The nurses accidentally allow him a cigar.'

(xv) ASP26: JEMANDEM ETWAS VERWEIGERN

"Die Behörde verweigerte ihm versehentlich das notwendige

the office refused he.DAT accidentally the.ACC.N necessary.ACC.N

Visum.

visa

'The office accidentally refused him the necessary visa.'

As opposed to the ASPs mentioned above, those listed beneath involve an Agent which may but need not have control over the action expressed by the verb:

(i) ASP10: ETWAS/JEMANDEN AUS ETWAS NEHMEN

Er hat das Handy versehentlich aus der Tasche genommen.

he has the.ACC.N mobile accidentally from the.DAT.F pocket taken

'He has accidentally taken his mobile from his pocket.'

(ii) ASP13: JEMANDEN/ETWAS ETWAS ENTFERNEN

Er entfernte dem Tier versehentlich zwei Federn.

he removed the.DAT.M animal accidentally two feathers

'He accidentally removed two feathers from the animal.' 
(iii) ASP14: ETWAS VON ETWAS ENTFERNEN

Sie entfernte versehentlich den Glasverschluss von der Flasche. she removed accidentally the.ACC.M glass top from the.DAT.F bottle 'She accidentally removed the glass top from the bottle.'

(iv) ASP15: ETWAS AUS ETWAS ENTFERNEN

Er hat versehentlich die Liebesszene aus dem Film entfernt. he has accidentally the.ACC.F love scene from the.DAT.M film removed 'He has accidentally removed the love scene from the film.'

(v) ASP17: ETWAS ETWAS HINZUFÜGEN

Er hat dem Dokument versehentlich seinen Namen hinzugefügt. he has the.DAT.N document accidentally his.ACC.M name.ACC added 'He has accidentally added his name to the document.'

(vi) ASP18: ETWAS AN ETWAS HINZUFÜGEN

Die Behörde hat am Ausweis versehentlich eine the office has at-the.DAT.M identity card accidentally a.ACC.F Angabe hinzugefügt. detail added

'The local authorities have accidentally added a personal detail to the identity card.'

(vii) ASP19: ETWAS ZU ETWAS HINZUFÜGEN

Er hat die Namen versehentlich zu der Liste hinzugefügt. he has the.PL.ACC names accidentally to the.DAT.F list added 'He has accidentally added the names to the list.'

(viii) ASP20: ETWAS IN ETWAS EINFÜGEN

Er hat die Abschnitte versehentlich in den Text eingefügt. he has the.PL.ACC passages accidentally into the.Acc.M text added 'He has accidentally added the passages to the text.'

On the whole, the Agent of a TC is a volitional Agent, either in the sense that he/she must have control over the transfer action or in the sense that he/she may control that action but does not necessarily do so.

\subsubsection{Animacy of the referent of the first object-NP}

In German, the first object-NP of a ditransitive construction does not necessarily refer to an animate entity. This is due to the fact that, in German, the ditransitive construction interacts not only with most of the types of verbs it has been described to interact with in English, but also with take-verbs, verbs of removal and add-verbs. When the ditransitive construction interacts with take-verbs and verbs of removal, the first object-NP refers to a Source. When the ditransitive construction interacts with add-verbs, the first object-NP refers to a Goal. The constraints on the first object-NP have been discussed with respect to English, where this constituent invariably seems to refer to a Recipient.

As pointed out above, take-verbs and verbs of removal require the first object-NP of a ditransitive construction to refer to an animate entity when the Source is a body and the Theme a part of that body as in dem Patienten einen Teil der Lunge entnehmen/entfernen 
(lit.: 'take out/remove the patient a part of the lung'). However, when there is no bodybody part relationship between Source and Theme, the first object-NP may refer either to an animate entity as in dem Dieb die Fesseln entfernen/abnehmen (lit.: 'remove/take off the thief the chains') or to an inanimate entity as in der Schublade ein Dokument entnehmen (lit.: 'take out the drawer a document').

When the ditransitive construction interacts with add-verbs the first object-NP almost always refers to an inanimate Goal as in dem Text einen Absatz hinzufügen ('add the text a passage'). An exception is implantieren ('implant'), which is used most frequently with an animate Goal.

\subsubsection{Willingness of the Recipient}

When the first object-NP of a German ditransitive construction refers to a Recipient, the Recipient is in most cases willing to accept the transferred entity. However, when the ditransitive construction occurs with verbs like aufzwingen and aufnötigen (both 'force something on someone'), which express a Recipient's reluctance to accept a transferred entity, the first object-NP refers to a Recipient who is not willing or at least reluctant to receive the transferred entity. Whether the Recipient is willing or not seems to depend on the meaning of the verb the double object pattern interacts with.

\section{Conclusion}

The TC has been shown to be a more heterogeneous phenomenon in German and Romanian than in English. This is due to the fact that, in both languages, the ditransitive pattern combines with take-verbs, verbs of removal and add-verbs, which do not allow the double object pattern in English. Since the German and Romanian ditransitive patterns with these verbs also have at least one prepositional variant, German and Romanian have a larger number of dative alternation types than English.

For German and Romanian, three main types of TCs must be distinguished, each of which may be realised by a double object as well as at least one prepositional pattern. TC1-TC 3 each combine with a different set of verbs and involve a different set of semantic roles:

(i) TCl: Transfer from an Agent to a Recipient

Roles: X: Agent; Y: Recipient; Z: Theme (transferred object)

Verbs: verbs of giving, general verbs of communication, verbs expressing a communication medium, some information verbs, some directive speech act verbs, a small number of expressive speech act verbs 
(ii) TC2: Transfer away from a Source

Roles: X: Agent; W: Source; Z: Theme (transferred object)

Verbs: take-verbs, verbs of removal

(iii) TC3: Transfer from an Agent to a Goal

Roles: X: Agent; U: Goal; Z: transferred object

Verbs: add-verbs

The TC has been shown to be realised in German as well as Romanian by a variety of different argument structure patterns. With the exception of the German variant of ASP13 (JEMANDEM/ETWAS ETWAS ENTFERNEN), all of these fulfil the requirements for argument structure patterns mentioned in section 4 :

(i) They all consist of an abstract verbal element and its argument slots.

(ii) At least one of these units is not characterised by lexical elements but by categorial semantic and/or syntactic specifications. Of all ASPs listed for German, only three are in fact partially characterised by lexical elements. This is true of ASP11 (JEMANDEN/ etwas einer SACHe BeraUben (lit.: 'rob someone/something something')), ASP12 (ETWAS BERAUBt JEMANDEN/ETWAS EINER SACHE (lit.: 'something robs someone/something something')) and ASP16 (SICH EINER SACHE BEMÄCHTIGEN (lit.: 'oneself of something seize')), which interact only with the verbs berauben (' $\mathrm{rob}$ ') and bemächtigen ('seize'), respectively. However, since these patterns also contain open slots for the subject- and object-NPs, they are only partially characterised by lexical elements and hence fulfil criterion (ii).

(iii) At least one formal or semantic aspect of these specifications does not follow from general specifications of the grammar (syntax/morphology/semantics/pragmatics) or of the lexicon. With the exception of ASP13 (JEMANDEM/ETWAS ETWAS ENTFERNEN (lit.: 'remove someone/something something')), all patterns listed have been shown to fulfil this criterion mainly because they are all at least partially unpredictable. Though the TC co-occurs with verbs of certain classes, not all verbs belonging to these interact with the TC. Within some of the verb classes which the TC has been shown to interact with, there are almost as many verbs which do not interact with the $\mathrm{TC}$ as such which do. This is true especially of ASP3 (ETWAS AN JEMANDEN ÜBERGEBEN ('hand something to someone')), ASP6 (JEMANDEM/ETWAS ETWAS NEIIMEN (lit:: 'take someone/something something')), and ASP21 (JEMANDEM/ETWAS ETWAS BESORGEN ('obtain someone/something something')) when it occurs with verbs of obtaining or commissive speech act verbs. Other ASPs are highly idiosyncratic in that they co-occur with only very few verbs or even with only one single verb. Examples are the ASPs comprising two accusative object-NPs, ASP2 (JEMANDEN ETWAS LEIREN ('teach someone something')) and ASP7 (JEMANDEN ETWAS ABFRAGEN (lit.: 'test someone something')), as well as ASP4 (JEMANDEN/ ETWAS MIT ETWAS VERSORGEN ('provide someone/something with something')), ASP11 (JEMANDEN/ETWAS EINER SACHe BERAUBEN (lit.: 'rob someone/something something')) and ASP16 (SICH EINER SACHE BEMÄCHTIGEN (lit.: 'seize oneself of something')). 
In addition to being partially productive, some ASPs extend the argument structure of the verbs they co-occur with. This is true of ASP21 (JEMANDEM ETWAS BESORGEN 'obtain someone something') when it co-occurs with obtain-verbs (besorgen ('get/obtain'), beschaffen ('supply'), kaufen ('buy'), etc.), verbs of creation (bauen ('build'), fertigen ('manufacture'), malen ('paint'), etc.), and search-verbs. These verbs inherently take two arguments, an Agent and a Theme. They gain a Recipient-argument when they co-occur with the DOC-pattern. The interaction of obtain-verbs, verbs of creation and search-verbs with the DOC-pattern (ASP21) yields a transfer meaning which is certainly not part of the meaning of these verbs. The interaction of ASP21 with these verbs therefore indicates that these patterns themselves must be associated with a transfer meaning.

With the exception of ASP21, all combinations of ASP1-ASP26 with individual verbs and/or verbs of specific classes could in principle be represented by valency grammars as well as construction grammars. Valency grammars treat argument structures as properties of lexical items and hence list possible argument structures separately for each individual lexical item. Construction grammars take argument structures to be a set of complex linguistic items existing independently of the verbs they occur with (see Stefanowitsch 2011 for a discussion of the advantages and disadvantages of valency grammars and construction grammars with respect to the productivity of certain argument structures). However, valency grammars fail to capture the generalisations regarding the interaction of the TC with verbs of specific classes. By listing argument structure patterns separately for individual lexical items, they wrongly suggest that verbs which may occur as part of a TC are scattered randomly over the entire lexicon. They also lack a mechanism to adequately describe the argument extensions and coercion effects brought about by the interaction of some verbs with the double object pattern.

Construction grammars, by contrast, have no difficulty in dealing with argument extensions and coercion effects. By assuming the existence of constructions with a particular form and a particular meaning which exist independently of the verbs with which they occur, they are able to account for cases where neither the additional argument (in the case of ASP21 the Recipient) nor the coercion effect observed (here the transfer meaning) can possibly be argued to originate within the verb. Cases where an ASP combines with only one verb can also easily be integrated into a construction grammar as lexically-bound argument structure constructions which exist alongside phrasal argument-structure constructions (cf. Stefanowitsch 2011: 383). From a constructionist point of view, lexicallybound argument constructions are low-level schemas which have not yet been abstracted away from the verbs they contain; phrasal argument structure constructions are higher-level schemas (cf. ibid.). However, construction grammars are not able to account for the fact that, within each of the verb classes the TC interacts with, there is a number of verbs which do not occur with it. A combination of valency grammar and construction grammar would seem to be required to deal with the partial productivity of the phenomenon at hand. 
With respect to the dative alternation, much of the data presented here supports the verb-sensitivity approach put forward for the English dative alternation by Rappaport Hovav/Levin (2008). According to these authors, analyses of the (English) dative alternation fall into one of two major classes: the single meaning approach or the multiple meaning approach. The former assumes that the double object variant and the to variant are associated with the same meaning, this allowing two argument realisation options. Examples of the single meaning approach are the generative accounts of the dative alternation by Baker (1988) and Larson (1988), which take the dative alternation to be triggered by an incorporated preposition whose complement is the Goal. (For a more detailed discussion of Larson 1988, see Tigău, this volume.) Rappaport Hovav/Levin (2008: 131) argue that Larson's and Baker's accounts do not explain (i) why a particular set of verbs should be associated with preposition incorporation, and (ii) why one variant is sometimes appropriate while the other is not (e.g., The noise gave Terry a headache. / The noise gave a headache to Terry.) Apart from Rappaport Hovav/Levin's criticism, this study has shown that at least two meanings, a caused possession meaning and a caused motion meaning, must be postulated to explain why the inference of successful transfer is available in sentences with verbs of giving but not in sentences with verbs of sending or verbs of obtaining in German.

On the second approach, the multiple meaning approach, the double object pattern and the to variant are associated with different but related meanings, with each meaning giving rise to a distinct argument realisation pattern. The double object pattern is taken to be associated with a caused possession meaning (i.e. the meaning of successful transfer discussed with respect to the alternation of ASP1 and ASP3) while the to variant is assumed to be associated with a caused motion meaning. Rappaport Hovav/Levin (2008: 131) point out that the multiple meaning approach currently is the dominant approach. As mentioned above, it has also been favoured in studies dealing with the dative alternation in German. Since the multiple meaning approach assumes each pattern to be invariably associated with one meaning, Rappaport Hovav/Levin call this approach the uniform multiple meaning approach.

Rappaport Hovav/Levin's account of the English dative alternation is a multiple meaning approach in as far as it assumes two meanings, caused possession and caused motion, to be involved in the English dative alternation. It differs from the uniform multiple meaning approach, however, in that it claims that the to variant may be associated both with the caused possession and the caused motion meaning; the double object pattern is assumed to be invariably associated with the caused possession meaning. Whether the to variant is associated with the caused possession or the caused motion meaning depends on the type of verb it occurs with. Give-type verbs are assumed to have a caused possession meaning, irrespective of whether they occur with the double object pattern or the to variant. However, verbs like throw and send are claimed to have both a caused motion meaning as in $I$ sent the package to London and a caused possession meaning as in I sent the package to my brother. 
The data presented in this study, especially with respect to the alternation between the double object pattern ASP1 and the an variant ASP3 and between the double object pattern ASP21 and its an variant ASP23, basically support an explanation of the dative alternation along the lines of Rappaport Hovav/Levin's verb-sensitive approach. German verbs of giving have been argued to be associated with a caused possession meaning, irrespective of whether they occur with the double object pattern or its an variant. German send- and $o b-$ tain-verbs have been claimed to be associated with the meaning of intended possession in the double object as well as the prepositional pattern when the intended Recipient is an animate entity. Neither of these verb classes seems to be compatible with an unambiguously inanimate Goal such as den Briefkasten ('the postbox') either in the double object or the prepositional pattern, cf. "IIch habe dem Briefkasten den Brief geschickt ('I have sent the postbox a letter') or 'Ich habe einen Brief an den Briefkasten geschickt ('I have sent a letter to the postbox'). When the Goal-argument is a location, it is realised as a PP headed by nach (lit.: 'after', here: 'to') as in Ich habe das Paket nach Paris geschickt ('I have sent the package to Paris'). When the first object-NP of a double object pattern refers to a location as in Ich habe Paris das Paket geschickt ('I have sent Paris the package'), it is interpreted as referring to a group of people situated in that location.

Like many other accounts of the dative alternation, the verb-sensitive approach has been proposed on the basis of English data. Accounts of the dative alternation have therefore concentrated on those alternation types which occur in English. German has been shown to possess dative alternations involving take-verbs, verbs of removal and addverbs in addition to those it shares with English. For German, the verb-sensitive account or indeed any other account of the dative alternation should be reconsidered taking into account precisely these alternations.

\section{References}

Allerton, David J. (1978): Generating indirect objects in English. In: Journal of Linguistics 14. 21-33.

Baker, Mark C. (1988): Incorporation: A theory of grammatical function changing. Chicago, IL: University of Chicago Press.

Boas, Hans C. (2010): The syntax-lexicon continuum in Construction Grammar: A case-study of English communication verbs. In: Belgian Journal of Linguistics 24. 54-82.

Colleman, Timothy (2010): The benefactive semantic potential of 'caused reception' constructions: A case study of English, German, French, and Dutch. In: Zúñiga, Fernando/Kittilä, Seppo (eds.): Benefactives and Malefactives: Typological perspectives and case studies. Amsterdam/Philadelphia: Benjamins. 219-243.

Croft, William (2003): Lexical Rules vs. Constructions: A False Dichotomy. In: Cuykens, Hubert et al. (eds.): Motivation in Language: Studies in Honor of Gunter Radden. Amsterdam/Philadelphia: Benjamins (= Amsterdam Studies in the Theory and History of Linguistic Science: Ser. 4, Current Issues in Linguistic Theory 243). 49-68.

Croft, William (2007): Construction Grammar. In: Geeraerts, Dirk/Cuykens, Hubert (eds.): The Oxford Handbook of Cognitive Linguistics. Oxford: Oxford University Press. 463-508. 
DEREKo (Deutsches Referenzkorpus): https://cosmas2.ids-mannheim.de/cosmas2-web

Dornseiff, Franz (2004): Der deutsche Wortschatz nach Sachgruppen. 8., völlig neu bearbeitete und mit einem vollständigen alphabetischen Zugriffsregister versehene Auflage von Uwe Quasthoff. Berlin: de Gruyter.

Duden (2006): Die Grammatik. Nach den Regeln der neuen deutschen Rechtschreibung 2006. Überarbeiteter Neudruck der 7., völlig neu erarbeiteten und erw. Aufl. Mannheim etc.: Dudenverlag (= Duden 4).

Dürscheid, Christa (1999): Die verbalen Kasus des Deutschen: Untersuchungen zur Syntax, Semantik und Perspektive. Berlin/New York: de Gruyter (= Studia linguistica Germanica 53).

ELR = Enciclopedia Limbii Române (2001). Bucharest: Univers Enciclopedic .

Engelberg, Stefan et al. (2011): Argumentstrukturmuster als Konstruktionen? Identität - Verwandtschaft -Idiosynkrasien. In: Engelberg, Stefan/Holler, Anke/Proost, Kristel (eds.): Sprachliches Wissen zwischen Lexikon und Grammatik. Berlin/Boston: de Gruyter (= Jahrbuch des Instituts für Deutsche Sprache 2010). 71-112.

Eroms, Hans-Werner (1978): Zur Konversion der Dativphrasen. In: Sprachwissenschaft 3. 357-405.

Erteschik-Shir, Nomi (1979): Discourse Constraints on Dative Movement. In: Givón, Talmy (ed.): Syntax and Semantics. Vol. 12: Discourse and Syntax. New York/San Francisco/London: Academic Press. 441-467.

E-Valbu: Das elektronische Valenzwörterbuch deutscher Verben. http://www.ids-mannheim.de/e-valbu

Fellbaum, Christiane (2005): Examining the Constraints on the Benefactive Alternation by Using the World Wide Web as a Corpus. In: Kepser, Stephan/Reis, Marga (eds.): Linguistic Evidence: Empirical, Theoretical and Computational Perspectives. Berlin/New York: de Gruyter (= Studies in generative grammar 85). 209-240.

GALR II (2008) = Gramatica limbii române. II. Enunțul. Academia Română, Institutul de Lingvistică "Torgu Iordan - Al. Rosetti". Coord: Valeria Guţu Romalo. Bucharest: Editura Academiei Române.

Goldberg, Adele E. (1992): The inherent semantics of argument structure: The case of the English ditransitive construction. In: Cognitive Linguistics 3. 37-74.

Goldberg, Adele E. (1995): Constructions: A Construction Grammar Approach to Argument Structure. Chicago/London: University of Chicago Press.

Goldberg, Adele E. (1998): The Relationships between Verbs and Constructions. In: Verspoor, Marjolijn H./Lee, Kee Dong/Sweetser, Eve (eds.): Lexical and Syntactical Constructions and the Construction of Meaning. Amsterdam/Philadelphia: Benjamins (= Current Issues in Linguistic Theory 150). 383-398.

Goldberg, Adele E. (2006): Constructions at Work: The Nature of Generalization in Language. Oxford: Oxford University Press.

Green, Georgia M. (1974): Semantics and Syntactic Regularity. Bloomington/London: Indiana University Press.

Gropen, Jess et al. (1989): The learnability and acquisition of the dative alternation in English. In: Language 65. 203-257.

Grundzüge einer deutschen Grammatik (1981). Von einem Autorenkollektiv unter der Leitung von Karl Erich Heidolph, Walter Flämig und Wolfgang Motsch. Berlin: Akademie-Verlag.

Harras, Gisela (2007): Lexikalische Strukturen der Repräsentative. In: Harras, Gisela/Proost, Kristel/ Winkler, Edeltraud. 73-124.

Harras, Gisela/Proost, Kristel/Winkler, Edeltraud (2007): Handbuch deutscher Kommunikationsverben. Bd. 2: Lexikalische Strukturen. Berlin/New York: de Gruyter (= Schriften des Instituts für Deutsche Sprache 10).

Larson, Richard K. (1988): On the double object construction. In: Linguistic Inquiry 19. 335-391.

Levin, Beth (1993): English Verb Classes and Alternations: A Preliminary Investigation. Chicago: University of Chicago Press.

Levin, Beth/Rappaport Hovav, Malka (2005): Argument Realization. Cambridge: CUP.

Mater, Erich (1971): Deutsche Verben. Bd. 6: Rektionsarten. Leipzig: VEB Bibliographisches Institut. 
Oehrle, Richard (1976): The grammatical Status of the English Dative Alternation. Cambridge, MA: MIT, Dept. of Linguistics.

Partee, Barbara Hall (1965): Subject and Object in Modern English. Ph. D. Diss. Cambridge, MA: MT. Reproduced in 1976 by L.A.U.T. (Linguistic Agency University of Trier).

Paul, Hermann (1959): Deutsche Grammatik. Bd. 3, Teil 4: Syntax (Erste Hälfte). 5. Aufl. Halle (Saale): VEB Max Niemeyer Verlag.

Pinker, Steven (1989): Leamability and Cognition: The Acquisition of Argument Structure. Cambridge, MA: MIT.

Primus, Beatrice (2012): Semantische Rollen. Heidelberg: Winter (= Kurze Einführungen in die germanistische Linguistik 12).

Proost, Kristel (2007): Lexikalische Strukturen der Expressive. In: Harras, Gisela/Proost, Kristel/Winkler, Edeltraud. 251-314.

Proost, Kristel (2009): Warum man nach Schnäppchen jagen, aber nicht nach Klamotten bummeln kann: Die $n a c h$-Konstruktion zwischen Lexikon und Grammatik. In: Winkler, Edeltraud (ed.): Konstruktionelle Varianz bei Verben. Mannheim: Institut für Deutsche Sprache (= OPAL-Sonderheft 4/2009). $10-41$.

Rappaport Hovav, Malka/Levin, Beth (2008): The English dative alternation: The cause for verb sensitivity. In: Journal of Linguistics 44. 129-167.

Reddy, Michael J. (1979): The Conduit Metaphor: A Case of Frame Conflict in Our Language about Language. In: Ortony, Andrew (ed.): Metaphor and Thought. Cambridge: Cambridge University Press. 284-324.

Rong, Du (2010): Zur Alternation von Doppelobjekt- und Präpositionalkonstruktionen bei Besitzwechselverben im Deutschen und Chinesischen: Eine kontrastive Untersuchung. Frankfurt am Main etc.: Lang (= Europäische Hochschulschriften 351).

Schumacher, Helmut et al. (2004): VALBU - Valenzwörterbuch deutscher Verben. Tübingen: Narr (= Studien zur deutschen Sprache 31).

Searle, John R. (1983): Intentionality: An essay in the philosophy of mind. Cambridge: Cambridge University Press.

Stefanowitsch, Anatol (2011): Argument Structure: Item-Based or Distributed? In: Zeitschrift für Anglistik und Amerikanistik 59. 369-386.

Tigău, Alina (in this volume): The Two-object construction in Romanian and German.

Timyam, Napasri/Bergen, Benjamin K. (2010): A contrastive study of the caused-motion and ditransitive constructions in English and Thai: Semantic and pragmatic constraints. In: Boas, Hans C. (ed.): Contrastive Studies in Construction Grammar. Amsterdam/Philadelphia: Benjamins (= Constructional Approaches to Language 10). 137-168.

Wegener, Heide (1985): Der Dativ im heutigen Deutsch. Tübingen: Narr (= Studien zur deutschen Grammatik 28).

Winkler, Edeltraud (2007a): Lexikalische Strukturen der Kommissive. In: Harras, Gisela/Proost, Kristel/Winkler, Edeltraud. 223-250.

Winkler, Edeltraud (2007b): Lexikalische Strukturen der Direktive. In: Harras, Gisela/Proost, Kristel/ Winkler, Edeltraud. 125-221.

Zifonun, Gisela/Hoffmann, Ludger/Strecker, Bruno (1997): Grammatik der deutschen Sprache. Berlin/ New York: de Gruyter (= Schriften des Instituts für Deutsche Sprache 7). 